\title{
MORTALITY ASSESSMENT OF REDWOOD AND MIXED CONIFER FOREST TYPES IN SANTA CRUZ COUNTY FOLLOWING WILDFIRE
}

\author{
A Thesis \\ presented to \\ the Faculty of California Polytechnic State University, \\ San Luis Obispo
}

\author{
In Partial Fulfillment \\ of the Requirements for the Degree \\ Master of Science in Forestry Science
}

(Natural Resources Management and Environmental Sciences Department)

by

Steve R. Auten

December 2012 
(C) 2012

Steve R. Auten

ALL RIGHTS RESERVED 
COMMITTEE MEMBERSHIP

TITLE: MORTALITY ASSESSMENT OF REDWOOD AND MIXED CONIFER FOREST TYPES IN SANTA CRUZ COUNTY FOLLOWING WILDFIRE

AUTHOR: Steven R. Auten - B.S. Forestry Science from Cal Poly in 1998, Resource Manager for Swanton Pacific Ranch, Registered Professional Forester, California, License No. 2734, Licensed Timber Operator, License No. C10977

DATE SUBMITED: $\quad$ December 2012

COMMITTEE CHAIR: Dr. Richard P. Thompson - Ph.D. in Natural Resources/Environmental Economics from Texas A\&M in 1990, tenured Cal Poly Professor since 1995, Registered Professional Forester, California, License No. 2455

COMMITEE MEMBER: Dr. Brian C. Dietterick - Ph.D. in Forest Hydrology from Penn State in 1994, tenured Cal Poly Professor, Professional hydrologist and Director of Swanton Pacific Ranch

COMMITTEE MEMBER: Dr. Robert J. Hrubes - Ph.D. in Wildland Resource Science from University of California, Berkeley in 1981, Executive Vice President of Scientific Certifications Systems, Registered Professional Forester, California, License No. 2228 


\begin{abstract}
MORTALITY ASSESSMENT OF REDWOOD AND MIXED CONIFER FOREST TYPES IN SANTA CRUZ COUNTY FOLLOWING WILDFIRE
\end{abstract}

By Steve R. Auten

On August 12, 2009, the Lockheed Fire ignited the west slope of the Santa Cruz Mountains burning approximately 7,819 acres. Foresters and other land managers were left with challenging decisions on how to evaluate tree mortality. Big Creek Lumber Company, California Polytechnic State University, San Luis Obispo (Cal Poly)’s Swanton Pacific Ranch (SPR), and other resource professionals familiar with this region teamed up to develop a method for evaluating damage and thereby mortality for redwood, California nutmeg, live oak, tanoak, California bay, Pacific madrone, big leaf maple, Douglas-fir, Monterey pine, and knobcone pine. Quantitative damage criteria were used to design three Mortality Assessment models (MA), divided into three diameter at breast height classes (1-8.9, 9-16.9, >17 inches), for all tree species. These models were compared against pre-fire data from 82, one-fifth acre fixed plots from SPR's Continuous Forest Inventory. Since the initial evaluation using the new MA in Fall 2009, each of the 2,877 trees were re-evaluated in Spring 2010 and Spring 2011 to determine if initial evaluations from the MA in 2009 were correct. To date, predictions to determine individual tree mortality using the Mortality Assessment models have been 89.3\% correct.

Keywords: redwood, conifer, hardwood, mortality 


\section{ACKNOWLEDGMENTS}

Special thanks to Dr. Richard Thompson for taking so much of his personal time to help me through this project even though it changed a few times. Sorry Rich. Thank you to Dr. Robert Hrubes for his "real world” commentary and advice in finalizing this thesis. Thank you to the unyielding field crew that spent countless hours in the woods gathering data for three years, especially Shane Larsen who was there for all three years. Thank you to Big Creek Lumber Company family and foresters for their knowledge and time spent in providing important information to this thesis. Thank you to the myriad of

other Registered Professional Foresters who provided their insights into wildfire and tree mortality at the CLFA breakfast at Swanton Pacific Ranch held several months after the Lockheed Fire. Thank you to Nadia Hamey for her work in co-authoring the publication on damage and mortality presented at the 2011 Redwood Symposium. Thank you to Dr. Brian Dietterick for supporting this project in so many ways, and more importantly supporting me, to make sure I finished my thesis. Thank you to Al Smith, whom I never had the honor of meeting, for your special gift to Cal Poly that also shaped the lives of my family. Lastly, thank you to my wife Patty for all of her love and support through this project. I promise to come home now... 


\section{TABLE OF CONTENTS}

Page

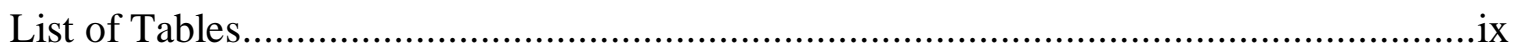

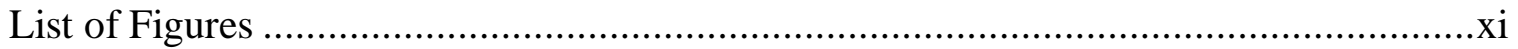

Chapter

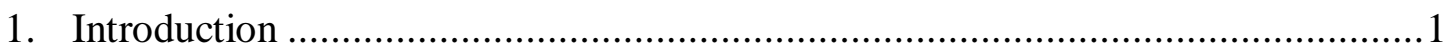

Swanton Pacific Ranch and the Non-industrial Timber Management Plan......1

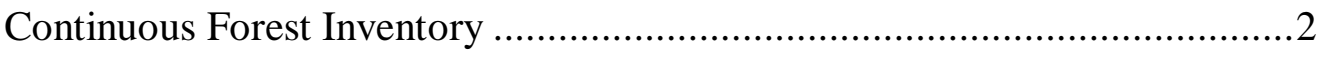

The Lockheed Fire ..............................................................................4

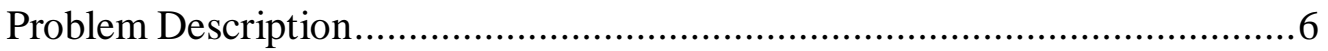

Hypothesis Statement .............................................................. 6

2. Previous Research............................................................................. 7

Professional Opinion on Damage in Redwoods and Other Coppice Sprouting Species .................................................................... 7

Scientific Literature on Mortality in Redwood and Douglas-fir................... 10

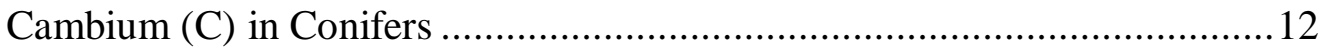

Roots (R) in Conifers, Especially Redwood..........................................12

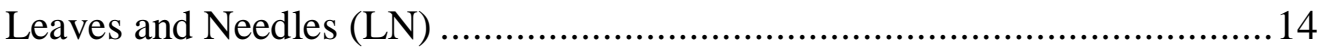

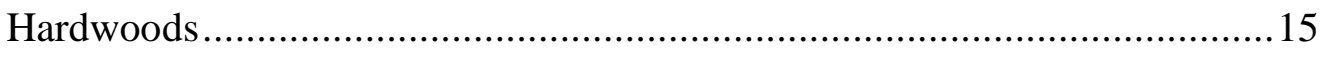

Tree Species of the Santa Cruz Mountains..................................................16

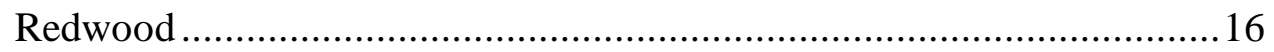

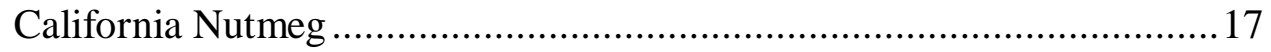

Live Oak ............................................................................. 17

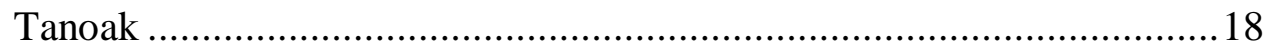


TABLE OF CONTENTS (continued)

Chapter

Red Alder ................................................................................. 18

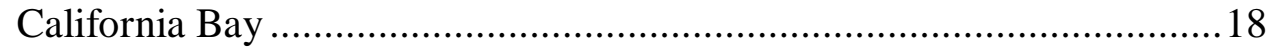

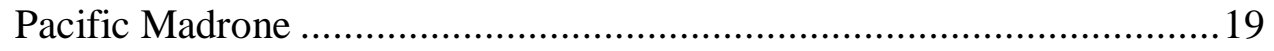

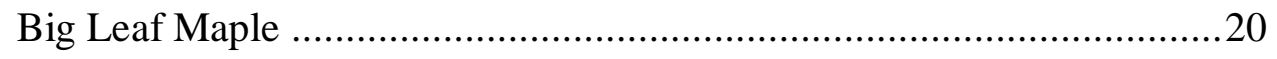

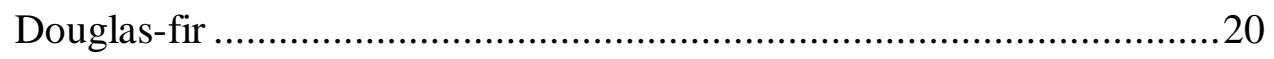

Monterey Pine .........................................................................22

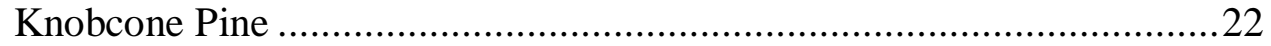

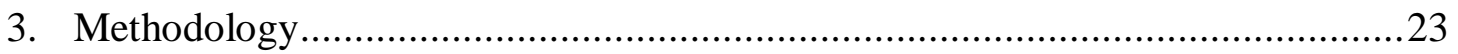

Measuring Mortality Assessment Model Variables ..................................23

Cambium Quadrants Destroyed by Fire (CQDF) ...............................23

Percent of Root System Missing (PRSM) ........................................224

Percent Canopy Remaining (PCR) ................................................22

Percent Canopy Sprouting (PCS) ................................................229

Mortality Assessment Model Thresholds ..............................................30

Testing the Mortality Assessment Model Using the Continuous Forest

Inventory System................................................................. 33

Accuracy of the Mortality Assessment Model .........................................36

Sustainability Analysis and Setting Mortality Assessment Model

Thresholds ............................................................................... 36

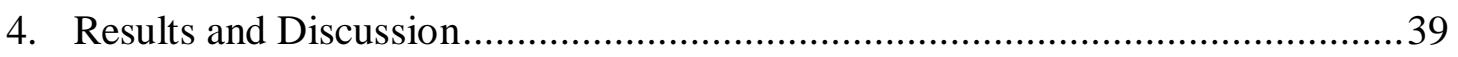

General Results and Discussion for the Mortality Assessment Model...........39

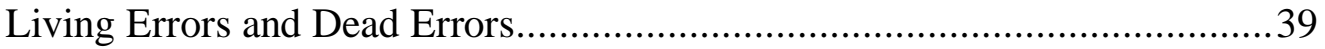


TABLE OF CONTENTS (continued)

Chapter $\quad$ Page

Results of Mortality Assessment Model by Species .................................44

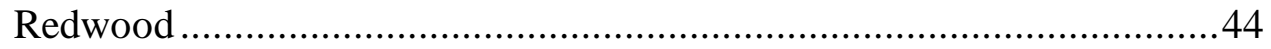

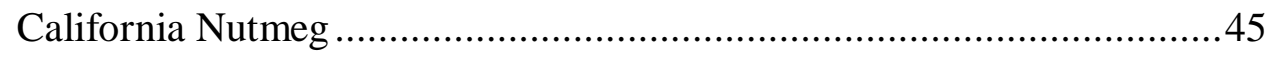

Live Oak ..............................................................................4 46

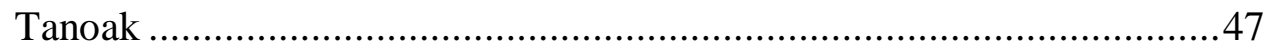

Red Alder .......................................................................... 48

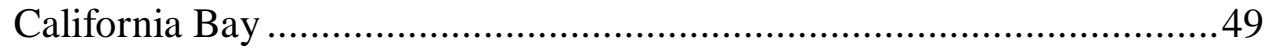

Pacific Madrone ...........................................................................50

Big Leaf Maple ...................................................................... 51

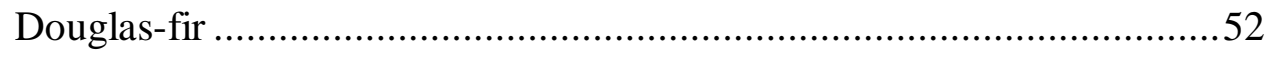

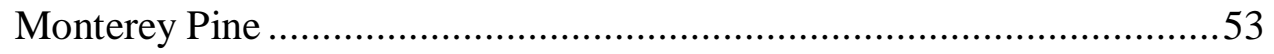

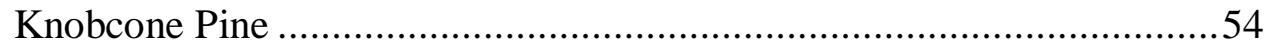

5. Conclusions and Recommendations .......................................................55

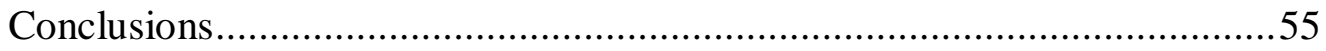

Recommendations for Replication of the MA Model................................57

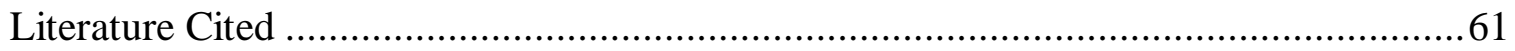

Appendices

A. Damage and Mortality Assessment of Redwood and Mixed Conifer Forest Types in Santa Cruz County Following Wildfire.....

B. PowerPoint Presentation from the 2011 Redwood Symposium.........................72

C. PowerPoint Presentation of Thesis Defense for "Mortality assessment of redwood and mixed conifer forest types in Santa Cruz County following wildfire". 


\section{LIST OF TABLES}

Table

Page

1. Lockheed Fire Watershed Statistics

2. Criteria for Survival Marking of Fire-scorched Timber in California

(Wagener 1961).....

3. Mortality Assessment Model for $1-8$ inch DBH Classes (1.0” - 8.9”) 32

4. Mortality Assessment Model for 9 - 16 inch DBH Classes (9.0” - 16.9”) ..........32

5. Mortality Assessment Model for $>17.0$ inch DBH Classes (>17.0”) ..................33

6. Sample Size by Tree Species Based on Diameter at Breast Height (DBH).........35

7. Summary Table Excerpt for Redwood Displaying 3 Years of MA

Evaluation $(\mathrm{d}=$ dead, $\mathrm{l}=$ live $)$

8. Percent Accuracy of the Mortality Assessment Model: $1.0-8.9$ inch DBH...... 40

9. Percent Accuracy of the Mortality Assessment Model: $9.0-16.9$ inch DBH.....40

10. Percent Accuracy of the Mortality Assessment Model: >17.0 inch DBH ..........41

11. Redwood Results Following 2 Years of Re-evaluation of the Mortality

Assessment Model

12. Redwood Statistics

13. California Nutmeg Results Following 2 Years of Re-evaluation of the Mortality Assessment Model

14. Live Oak Results Following 2 Years of Re-evaluation of the Mortality Assessment Model 46

15. Live Oak Statistics

16. Tanoak Results Following 2 Years of Re-evaluation of the Mortality Assessment Model

17. Tanoak Statistics . 


\section{LIST OF TABLES (continued)}

Table

18. Red Alder Results Following 2 Years of Re-evaluation of the Mortality Assessment Model

19. California Bay Results Following 2 Years of Re-evaluation of the Mortality Assessment Model

20. California Bay Statistics

21. Pacific Madrone Results Following 2 Years of Re-evaluation of the Mortality Assessment Model.

22. Pacific Madrone Statistics

23. Big Leaf Maple Results Following 2 Years of Re-evaluation of the Mortality Assessment Model

24. Douglas-fir Results Following 2 Years of Re-evaluation of the Mortality Assessment Model

25. Douglas-fir Statistics

26. Monterey Pine Results Following 2 Years of Re-evaluation of the Mortality Assessment Model

27. Monterey Pine Statistics

28. Knobcone Pine Results Following 2 Years of Re-evaluation of the Mortality Assessment Model

29. Adjusted Mortality Assessment Model for 1.0 - 8.9 inch DBH Classes..............58

30. Adjusted Mortality Assessment Model for 9.0 - 16.9 inch DBH Classes ............ 59

31. Adjusted Mortality Assessment Model for $>17.0$ inch DBH Classes ..................59 


\section{LIST OF FIGURES}

Figure $\quad$ Page

1. Swanton Pacific Ranch NTMP, CFI Plots, and Stand Types...............................

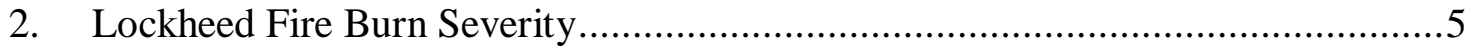

3. Fungus on Bark Representing Dead Cambium Underneath Bark ......................25

4. Evidence of Active Cambial Growth Underneath Bark.....................................25

5. Cambial Growth in Center of Photo Subsuming Damaged Area on Live Oak.....26

6. Method of Cylinder Breakdown to Evaluate Cambium Mortality ......................26

7. Arrows Indicating Location of Lateral Root Systems on Douglas-fir .................28

8. Arrows Indicating Voids Around Live Oak Tree Where Roots Where Consumed by Wildfire .........................................................................228

9. Two-dimensional Illustration of Percent Canopy Remaining Estimation ...........29

10. Illustration of Approximately 100\% Canopy Sprouting on Redwood

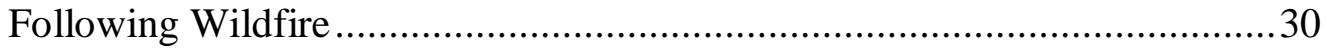

11. Picture of Re-measured CFI Plot Post-fire ...............................................35 


\section{CHAPTER 1}

Introduction

\section{Swanton Pacific Ranch and the Non-industrial Timber Management Plan}

Swanton Pacific Ranch (SPR) is a 3,282 acre working ranch operated for educational and research purposes and managed by the College of Agriculture, Food and Environmental Sciences from California Polytechnic State University, San Luis Obispo (Cal Poly). The Ranch was donated to Cal Poly by alumnus Al Smith in 1994, following his passing. Al held degrees in both Crop Science and Agricultural Education, and went on to teach high school agriculture, was elected mayor of Los Gatos, and was the founder of Orchard Supply Hardware. He wanted to provide Cal Poly students and faculty with a unique interdisciplinary environment to foster the "learn by doing" philosophy forever.

One of the interdisciplinary environments at SPR is the working forest, comprising approximately 1,308 acres of the total ranch acreage. In 2008, SPR filed a Non-industrial Timber Management Plan (NTMP) with the State. Approved in 2008, the NTMP is a long-term management document for private landowners with less than 2,500 acres of timberland that permits harvesting in perpetuity over 701 acres on SPR. The NTMP is functionally equivalent to an Environmental Impact Report complying with the California Environmental Quality Act (CEQA). The NTMP is also required to include a Sustainability Analysis (SA), a document that measures through forest inventory data whether the forest can maintain a sustainable level of harvest over time. The harvesting 
philosophy for a forest managed under an NTMP should be one that focuses on harvesting the growth (interest) of the forest over time ensuring that enough trees (capital) are left behind to sustain the harvest, perpetually. The intent of each timber harvest within the NTMP is to support the sustainable production of resources, as well as to protect the beneficial uses of the forest such as water, soil, flora, and fauna.

\section{Continuous Forest Inventory}

The SPR SA is based on a type of forest inventory called Continuous Forest Inventory (CFI). The SPR CFI plots are one-fifth acre fixed circular plots placed in a grid layout on a 500’ x 500’ spacing covering the NTMP area. The CFI plots are measured, using a systematic random sampling system, every 10 years (see Figure 1). The plots were first installed in the SPR forest for the NTMP area in 1997. More plots were added in 2003, and the 1997 CFI plots were re-measured in 2008. The SPR CFI samples approximately two to three percent of the forested area. Although this may be considered a low-intensity sample compared to most forest inventories, the SPR CFI system excels in sampling intensity within the plot at $100 \%$. All trees in the plot are measured starting at one inch Diameter at Breast Height (DBH). Some plots have as many as 150 trees, but usually average between $70-100$ trees. Each tree is numbered and has a distance and bearing recorded to plot center so it can be tracked over time. This means that prior to the Lockheed Fire in 2009, a substantial number of trees in the SPR forest, nearly 4,000, had detailed information already recorded from 2008 and 2003. 


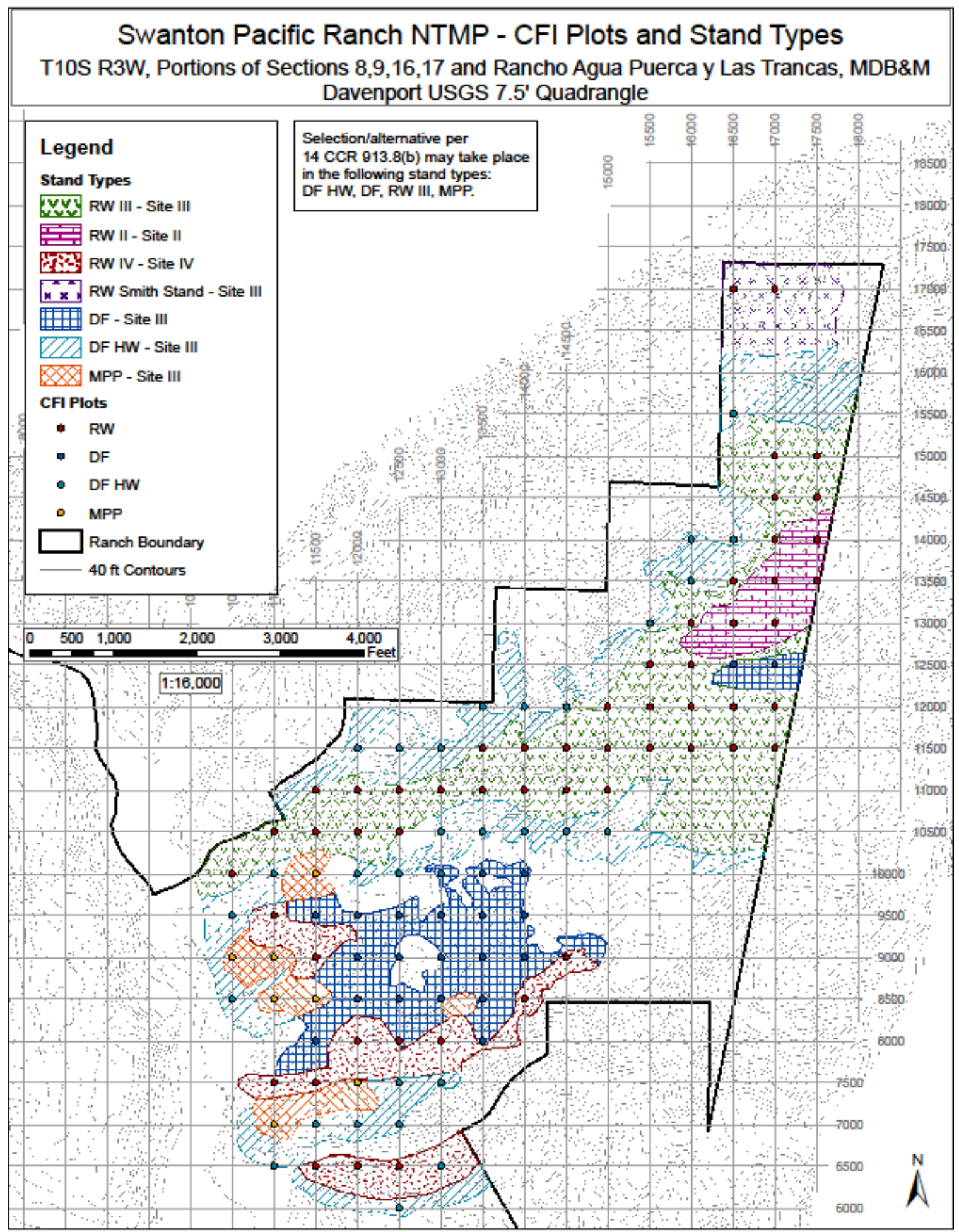

Fig. 1. Swanton Pacific Ranch NTMP, CFI Plots, and Stand Types. 


\section{The Lockheed Fire}

On August 12, 2009 at 7:15 p.m., the Lockheed Fire ignited the west slope of the Santa Cruz Mountains north of Davenport burning approximately 7,819 acres. A total of 1,142 acres of Swanton Pacific Ranch burned, including forest within the NTMP area (Table 1). Most importantly for the purpose of this project, 556 acres or $79 \%$ of the 2008 approved NTMP area (Little Creek, Winter Creek, and Archibald Creek) burned with varying levels of severity (Figure 2). A mixture of vegetation types were in the path of the fire, including approximately 2,420 acres of redwood forest and 1,951 acres of mixed conifer forest types representative of the Santa Cruz Mountains.

Table 1. Lockheed Fire Watershed Statistics

\begin{tabular}{|l|c|c|c|}
\hline Watershed & $\begin{array}{c}\text { Total } \\
\text { Area } \\
\text { Ac. }\end{array}$ & $\begin{array}{c}\text { Area } \\
\text { Burned } \\
\text { Ac. }\end{array}$ & $\begin{array}{c}\text { Area } \\
\text { Burned } \\
\text { in Percent }\end{array}$ \\
\hline Swanton NTMP in Little Creek & 701 & 556 & $79 \%$ \\
\hline Winter Creek & 116 & 94 & $81 \%$ \\
\hline Archibald Creek & 421 & 369 & $88 \%$ \\
\hline Little Creek & 1306 & 1200 & $92 \%$ \\
\hline Scotts Creek & 19001 & 6755 & $36 \%$ \\
\hline
\end{tabular}




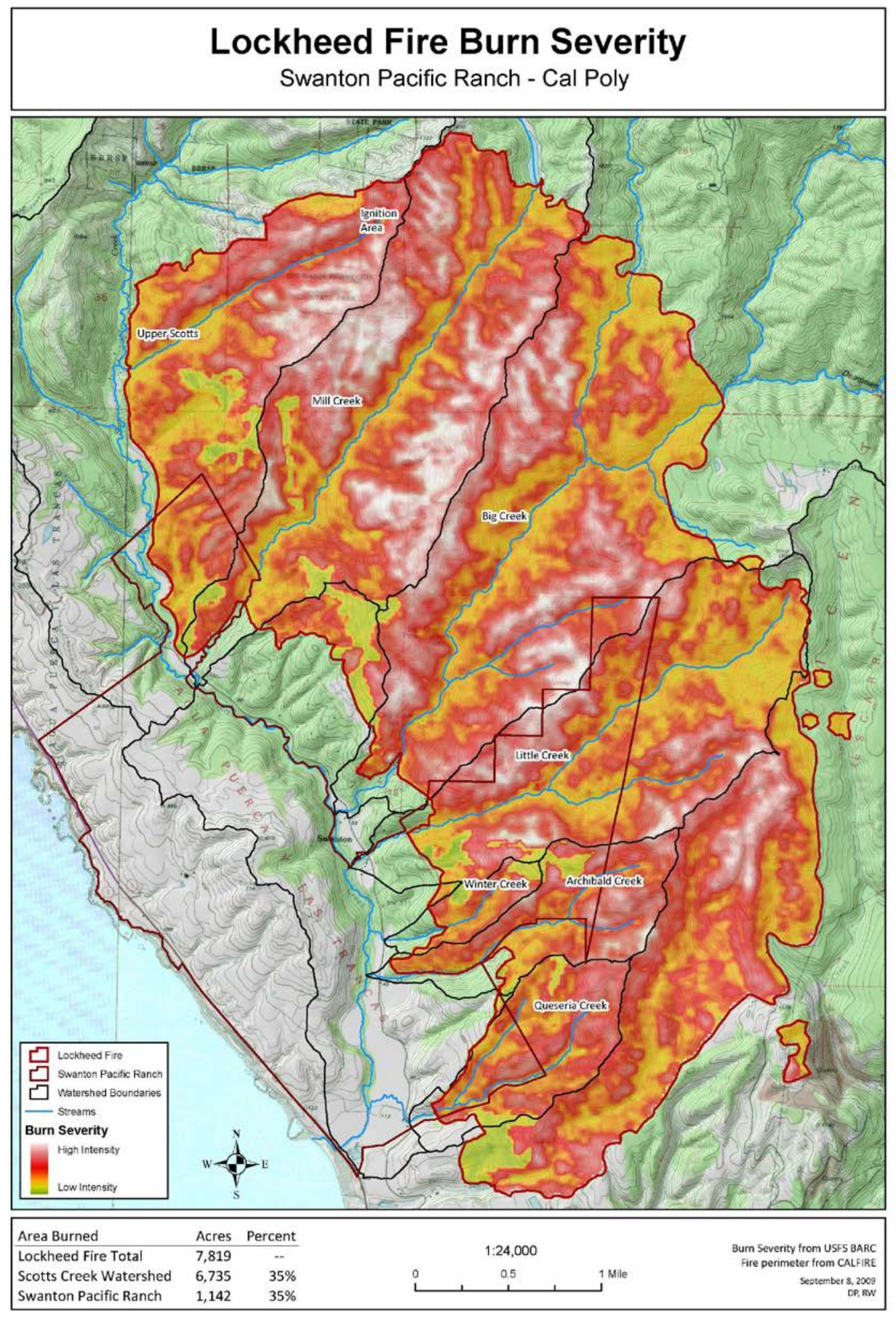

Fig. 2. Lockheed Fire Burn Severity. (Slightly darker red line indicates SPR boundary.) 


\section{Problem Description}

The Non-Industrial Timber Management Plan (NTMP) and Sustainability Analysis (SA) were based upon the Continuous Forest Inventory (CFI) data prior to the Lockheed Fire of 2009. The NTMP will be invalidated by the State if the NTMP and SA are not amended to reflect the changes in forest inventory due to the Lockheed Fire. The CFI plots in the burn area needed to be re-evaluated immediately following the fire to determine what trees would live or die. Scheduled long-term forest management plans depended on that information. A quick and reliable field technique to determine tree mortality is required. This is also the case with any other forest landowner who is faced with predicting the effects of a fire, especially those with regulatory agreements in place.

\section{Hypothesis Statement}

Mortality assessment models based on professional opinion and related research can accurately predict the mortality of trees in redwood and mixed conifer forest types in Santa Cruz County immediately following wildfire. 


\section{CHAPTER 2}

Previous Research

\section{Professional Opinion on Damage in Redwoods and Other Coppice Sprouting Species}

Since second-growth redwood comprises about 95\% of California’s coastal redwood commercial forest, it is very important to understand redwood resilience to disturbances such as fire. The market value of other species, e.g. Douglas-fir, is so low that salvage logging is not cost-effective; this is not the case for redwood.

As Big Creek Lumber Company and SPR professionals evaluated the damage and mortality from the Lockheed Fire, considerable uncertainty existed. Little scientific literature was available to inform the mortality assessment on coastal redwoods.

Similarities could be drawn from the research, but it was predominantly unchartered territory for this forest type. One published paper exists on mortality and prescribed fire in redwood, Finney (1993), but virtually no research exists on hardwoods in the coastal region. Significant amounts of research, however, were easily located on Sierra conifer species which helped guide the creation of the Mortality Assessment (MA) model for non-coppice (sprouting) species.

Many field hours were spent by foresters evaluating burn severity and correlating it to tree damage and mortality. More specifically, this evaluation focused on cambium damage, root damage, crown scorch, crown sprouting, and in part relying upon historic fire effects from the 1948 Pine Mountain Fire. Communications between other resource 
professionals and those specifically with recent wildfire experience in California redwood region proved invaluable. Providing both technical and field information on damage and mortality prediction, the following professionals were consulted:

- Mike Jani and John Anderson, Registered Professional Foresters from Mendocino Redwood Company, with experience in 2008 conducting salvage operations on the Lightning Complex Fire

- Lathrop Leonard from California State Parks with experience in prescribed burning

- Rich Casale, District Conservationist, USDA Natural Resources Conservation Service

- David Van Lennep and Mike Duffy, Registered Professional Foresters from Redwood Empire Sawmills, with experience in the 2008 Summit Fire and the 2004 Croy Fire, both in the Santa Cruz Mountains

- Dale Holderman, Chief Forester Emeritus for Big Creek Lumber Company, with significant experience in assessing tree defect in redwoods in the Santa Cruz Mountains

Professional opinion from local foresters evaluating the effects of burn severity in the redwood region focused on three main topics: basic physical characteristics that a tree needs to survive, distinctive survival abilities of sprouting species in the redwood region, and tree damage evaluation techniques.

The basic physical characteristics that a tree needs to live are Cambium (C), Roots (R), Leaves and Needles (LN). Cambium acts as a very thin layer of tissue that produces a layer of wood growth each year. Roots absorb water, nutrients, store sugars, and act as 
an anchor to stabilize the tree. Leaves and needles contain chlorophyll which facilitates photosynthetic activity. Photosynthesis uses the sun's energy to convert carbon dioxide from the atmosphere and water from the soil to create sugar and oxygen. The sugar is stored as carbohydrates in the branches, trunk and roots (Parts of a Tree, 2012). The connection between C, R, and LN is that each characteristic plays a crucial role in the survival of a tree. A tree can live with a percentage of C, R, and LN, but if a tree is completely missing any one of these characteristics the tree will die. Professional opinion from local foresters strongly supported the evaluation of these characteristics as a major component to the Mortality Assessment (MA) model. See the methodology section for a detailed discussion on how $\mathrm{C}, \mathrm{R}$, and $\mathrm{LN}$ were evaluated in the MA.

It was widely accepted among forestry professionals in the redwood region that sprouting species, suffering from the effects of wildfire, share a combination of evolutionary characteristics that other non-sprouting species do not have. Axillary buds not destroyed by the severity of wildfire will begin sprouting new leaves and needles within months following the cessation of fire. This sprouting behavior acts as a timely surrogate for photosynthetic activity to continue through the forest fire recovery phase. The creation of sugars, following a significant level of crown consumption from wildfire, helps the tree maintain a more vigorous existence through the recovery phase of fireinduced severity than a non-sprouting tree species. This added vigor, combined with stored carbohydrates, partially damaged roots, and cambium can provide an impressive resilience against wildfire that few other species share. Forestry professionals in the redwood region agreed that the percent of canopy sprouting should be evaluated as part of the MA model. 
Two tree damage evaluation techniques were developed by local foresters following months of tree damage field reconnaissance in the Lockheed Fire burn area: sounding the tree to determine cambial death, and probing around the tree to locate tree roots. Refer to the Methodology section for a more detailed protocol on how these measurements were conducted in the MA model. Also, see Appendix A for "Damage and mortality assessment of redwood and mixed conifer forest types in Santa Cruz County following wildfire” Auten (2011). This document provides information presented at the Redwood Science Symposium held at the University of California at Santa Cruz in June of 2011.

\section{$\underline{\text { Scientific Literature on Mortality in Redwood and Douglas-fir }}$}

During the period of time when foresters gathered information on damage and mortality based on professional opinion and field observation, scientific literature was also being gathered on damage and mortality. Tree species in the coastal region vary greatly in physical and life-cycle characteristics, from thin-barked red alder that live about 50 - 60 years to the thick barked, towering redwoods that can live much longer. What these coastal species all have in common is fire-induced mortality that is dependent on their physiologic mechanisms that grow wood, transport water, and create energy; Cambium, Roots, Leaves and Needles (CRLN).

The first scientific literature that stood apart from the others in mortality assessment was "Guidelines for Estimating the Survival of Fire-damaged Trees in California” (Wagener, 1961). Wagener was the first researcher to develop a qualitative field evaluation for tree mortality, giving the field forester much improved observational 
tools for identifying mortality characteristics. See Wagener’s “Criteria for survival marking of fire-scorched timber in California” (Table 2).

Table 2. Criteria for Survival Marking of Fire-scorched Timber in California (Wagener 1961)

\begin{tabular}{|c|c|c|c|c|c|c|}
\hline \multirow{3}{*}{ Influencing Factors } & \multicolumn{6}{|c|}{ Minimum Crite ria for Survival of - } \\
\hline & \multicolumn{3}{|c|}{$\begin{array}{l}\text { Ponderosa Pine } \\
\text { Jeffery Pine }\end{array}$} & \multicolumn{3}{|c|}{$\begin{array}{ll}\text { Sugar Pine } & \text { Red-fir } \\
\text { Douglas-fir* } & \text { Incense-cedar } \\
\text { White fir } \quad \text { Giant sequioa } \\
\end{array}$} \\
\hline & $\begin{array}{l}\text { Cambium } \\
\text { injury }\end{array}$ & $\begin{array}{l}\text { Live } \\
\text { crown }\end{array}$ & $\begin{array}{l}\text { Green } \\
\text { foliage }\end{array}$ & $\begin{array}{l}\text { Cambium } \\
\text { injury** }\end{array}$ & $\begin{array}{l}\text { Live } \\
\text { crown }\end{array}$ & $\begin{array}{l}\text { Green } \\
\text { foliage }\end{array}$ \\
\hline General Specifications & \multicolumn{6}{|c|}{ Percent } \\
\hline $\begin{array}{l}\text { Fire period - late season } \\
\text { Site quality - above average } \\
\text { Gorwth vigor of tree before } \\
\text { fire - good }\end{array}$ & $\begin{array}{l}\text { None or } \\
\text { light }\end{array}$ & $\begin{array}{l}50 \text { or } \\
\text { more }\end{array}$ & $\begin{array}{l}10 \text { or } \\
\text { more } * * *\end{array}$ & $\begin{array}{l}\text { None to } \\
\text { moderate }\end{array}$ & $\begin{array}{l}45 \text { or } \\
\text { more }\end{array}$ & $\begin{array}{l}35 \text { or } \\
\text { more }\end{array}$ \\
\hline \multicolumn{7}{|l|}{ Modifications } \\
\hline $\begin{array}{l}\text { In cambium injury - } \\
\text { general specifications as above }\end{array}$ & Moderate & $\begin{array}{l}50 \text { or } \\
\text { more }\end{array}$ & $\begin{array}{l}20 \text { or } \\
\text { more }\end{array}$ & - & $\longrightarrow$ & 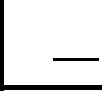 \\
\hline $\begin{array}{l}\text { In site - below average } \\
\text { Sierra East Side and } \\
\text { West Side, other general } \\
\text { specifcations unchanged }\end{array}$ & $\begin{array}{l}\text { None or } \\
\text { light }\end{array}$ & $\begin{array}{l}50 \text { or } \\
\text { more }\end{array}$ & $\begin{array}{l}15 \text { or } \\
\text { more }\end{array}$ & $\begin{array}{l}\text { None to } \\
\text { moderate }\end{array}$ & $\begin{array}{l}50 \text { or } \\
\text { more }\end{array}$ & $\begin{array}{l}40 \text { or } \\
\text { more }\end{array}$ \\
\hline $\begin{array}{l}\text { In fire period - midseason } \\
\text { other general specifcations } \\
\text { unchanged }\end{array}$ & $\begin{array}{l}\text { None or } \\
\text { light }\end{array}$ & $\begin{array}{l}50 \text { or } \\
\text { more }\end{array}$ & $\begin{array}{l}15 \text { to } \\
25 \text { or } \\
\text { more }\end{array}$ & $\begin{array}{l}\text { None to } \\
\text { moderate }\end{array}$ & $\begin{array}{l}50 \text { or } \\
\text { more }\end{array}$ & $\begin{array}{l}40 \text { to } \\
50 \text { or } \\
\text { more }\end{array}$ \\
\hline $\begin{array}{r}\text { In growth vigor - crown small, vigor } \\
\text { moderate, other general } \\
\text { specifications unchanged }\end{array}$ & $\begin{array}{l}\text { None or } \\
\text { light }\end{array}$ & $\begin{array}{l}60 \text { or } \\
\text { more }\end{array}$ & $\begin{array}{l}15 \text { or } \\
\text { more }\end{array}$ & $\begin{array}{l}\text { None to } \\
\text { moderate }\end{array}$ & $\begin{array}{l}55 \text { or } \\
\text { more }\end{array}$ & $\begin{array}{l}45 \text { or } \\
\text { more }\end{array}$ \\
\hline
\end{tabular}

* Does not include bigcone Douglas-fir. In this species the percent of live crown is not readily determinable; green foliage should be 20 percent or more.

** In sugar pine, includes up to 60 percent basal girdling.

*** Not an actual green foliage minimum for survival. Seventy percent of the pines in the study with 50 percent or more of live crown but with less than 10 percent of green foliage survived.

The research results reported in Wagener (1961) were re-evaluated some 24 years later by Weatherspoon (1987). At that time, Weatherspoon concluded that "given their 
geographic and species coverage, and their consideration of cambium as well as crown damage, Wagener's guidelines remain the best available for these species in California."

\section{Cambium (C) in Conifers}

Several authors address mortality for multiple Sierra species. Although Hood (2008) and Ryan (1988) focus predominantly on crown scorch and crown consumption, the loss of cambium as well was also considered. Smith (2009) uses DBH classes as breaks between mortality suggesting that DBH plays a major role in the survivability of pine and fir species. Fowler (2004) discusses this at length, suggesting that bark thickness and diameter are major factors in mortality rates and wildfire. These two factors play a primary role that relates to the shielding of heat and increased surface area as tree diameter increases, thus influencing survivability. These evaluation techniques all point to the importance of evaluating cambium as a major component of survivability. Peterson and Arbaugh (1989) and Ryan et al. (1988) studied Douglas-fir using chemical tests for the enzyme peroxidase to indicate live/dead cambium layers taken from four increment borer samples: upslope, downslope, and both cross-slopes. Exploring the cambium, the live tissue layer under the bark, is another method to determine cambium viability, but both of these methods are labor-intensive and expensive for landowners and foresters who need immediate information.

\section{Roots (R) in Conifers, Especially Redwood}

Although many local foresters managing lands affected by the Lockheed Fire appreciated the findings in Wagener's field-based approach, there were no attributes that considered root loss as a result of wildfire as it relates to tree mortality. Most root 
systems for species in the redwood region extend laterally at depths within a few feet of the surface (Burns, 1990). Roots are critical as a transport mechanism for nutrients, water, and for the stability of the tree; as such, damage to roots adversely impact tree survivability. Weatherspoon (1987) discussed root loss as it correlates to root depth connected to fire, and Regelbrugge (1993) looked at root damage as a major source of tree injury following fire. Finney (1993) determined that the significance of surface fuel consumption in all models of redwood top killing is likely related to damage of both the stem cambium and roots. Ryan (1992) stated that tree mortality has often been modeled as a function of tree size and fire damage to foliage, stem, and roots. Fritz (1932) made an interesting comment about the cause of spike tops in redwoods. He related the presence of spike tops in redwoods to the incidence of basal cambium damage due to fire, resulting in the reduction of the efficiency of the transport mechanism, including roots, to draw water nutrients to the top of the tree. This finding suggests a relationship between mortality and root loss as well. Damage and mortality observations made from the Lockheed Fire suggest that if basal cambium was affected, it was very likely that extensive surface root damage was also clearly evident.

Because redwoods are such prolific sprouters among other sprouting species in the redwood region, a major consideration for redwood mortality is the root condition. Finney (1993) agrees that current models of conifer mortality are probably not applicable to redwood due to its pronounced sprouting ability. Most literature reviewed has mentioned the importance of roots, but none has quantified the importance to disturbance survival. Studies by Wagener, Weatherspoon, Ryan, and Regelbrugge primarily focused on the Sierra mixed conifer forest where mortality is more clearly linked to the 
percentage of crown remaining, $\mathrm{DBH}$ and cambium, than it is in the redwood forest. In Sierra mixed conifers, if the cambium is girdled from wildfire the tree will die regardless of the condition of the root system. In coast redwood and associated sprouting species, local professional experts agree that the root system is an extremely important factor in tree survival. In these species, the cambium may be nearly girdled from wildfire but if the root system is intact the tree has a higher likelihood of survival due to its resilient sprouting ability.

\section{Leaves and Needles (LN)}

Wagener (1961) set parameters for crown remaining and cambial death as indicators of mortality for Douglas-fir and other Sierra mixed conifer species. This was the accepted method for many years as supported by Weatherspoon (1987). Around the time of Weatherspoon supporting Wagener's guidelines, a significant amount of research followed. Hood (2007) predicted mortality using percent crown length kill and cambium kill in all optimal models for Douglas-fir. Fowler (2004) stated that crown scorch volume were clearly the best crown damage measurement to predict post fire mortality of Douglas-fir, citing Peterson (1984 and 1985), Peterson and Arbaugh (1986 and 1989), and Ryan et al. (1988). However, Ryan et al. (1988) reported that cambial death measured directly was a better predictor of Douglas-fir tree mortality than crown scorching. Ryan et al. (1988) and Fowler (2004), however, did not agree on the best predictor of mortality. Ryan (1988) suggested that measuring cambium (C) impact was better at predicting mortality. Fowler (2004) suggested that crown length kill (Leaves and Needles (LN)) was the better predictor. The important point made by all of these studies is that a tree cannot live without cambium, and a tree cannot live without crown. 
It is generally accepted that a tree can live with a little of both, yet recognizing that each characteristic is important to a tree's survival.

Finney (1993) suggested two other helpful components for field evaluation associated with mortality related to LN. He wrote, "First, nonlinear and logistic models of plot-level data at the Humboldt redwood site suggested higher rates of top killing for redwood trees encircling stumps, compared with trees growing singularly. Secondly, convection appeared to be concentrated upward from within the sprout circle due to higher fuel loadings in the burning stump. Increased stem and crown damage is therefore likely to elevate top killing of sprout origin trees.” Field evaluations following the Lockheed Fire supported Finney’s findings. Some redwood groves smoldered for months on lands of Big Creek and Swanton Pacific Ranch.

\section{Hardwoods}

Research on wildfire-related mortality in hardwoods substantiating a correlation to cambium, roots, leaves and needles was difficult to find in the coastal redwood region. Loomis (1973) studied Oak-Hickory forests in the central and eastern United States. He pursued similar avenues to determine mortality for hardwoods, as discussed for fir and redwood, studying heat related to bark char and cambium. Loomis reported differences in survival based on the tree diameter and cambium damage as key indicators for mortality. He provided a key observation stating, "Wounds are often evident if growth has occurred since the fire. Cracking of bark along the wound margins or unevenness of the bole may show where callus growth is forming." This observation proved to be an excellent bit of advice that became evident within 2-4 months after the Lockheed Fire. 
As the trees began to grow again, this description of new growth near dead cambium was clearly evident.

\section{Tree Species of the Santa Cruz Mountains}

Another important component to developing a Mortality Assessment (MA) model for each tree species in the Santa Cruz Mountains is the evaluation of tree resilience to wildfire, not only by tree size, but its physical characteristics. Many tree species in the Santa Cruz Mountains are known to be coppice or sprouting species, but each differ widely among physical characteristics: bark thickness, tree size, rooting depth and structure. The information provided by species was utilized to assist in creating the MA model.

\section{Redwood (Sequoia sempervirens)}

Redwood is well known for its resilience to fire and was given the highest thresholds for mortality in the MA model across all categories. Found in groves of trees and sometimes singly-spaced specimens, its bark thickness, rooting matrices, and sprouting abilities make redwood trees of larger diameters difficult to penetrate. On the

other hand, the above-ground portions of younger, smaller stands may be killed outright by a single ground fire (Burns 1990).

- Cambium (C) - well protected in the larger DBH's. Small to mid-range DBH's offer fair protection to cambium with thinner bark and less surface area.

- Roots (R) - redwoods have no taproots, but lateral roots are large and wide spreading (Burns 1990). 
- Leaves and Needles (LN) - known for its abundant sprouting ability if its axillary buds are not completely burned

\section{California Nutmeg (Torreya californica)}

California nutmeg is not known for being fire resilient and is limited in occurrence on SPR. It has minimal sprouting ability on the stem.

- Cambium (C) - bark protection to cambium is minimal in all diameter classes, with bark thickness ranging from approximately $1 / 8^{\text {th }}-1 / 2^{\text {” }}$ in diameter

- Roots (R) - a stump and crown sprouter with lateral rooting structure that predominantly travels within less than a foot of the surface of the ground

- Leaves and Needles (LN) - some sprouting capabilities, but not a great deal of vigor offered from crown recovery following wildfire

\section{Live Oak (Quercus agrifolia)}

Live oaks are known for some resilience to fire, especially in the larger diameter classes coupled with a fairly aggressive sprouting ability.

- Cambium (C) - Small to mid-range DBH's offer poor to fair protection to cambium with thinner bark and less surface area; well protected in the larger DBH's

- Roots (R) - have taproots and lateral roots that can extend several feet into the ground

- Leaves and Needles (LN) - known for its aggressive sprouting abilities if its axillary buds are not completely burned 


\section{Tanoak (Notholithocarpus densiflorus)}

Tanoak is known for a moderate resilience to fire, especially in the larger diameter classes coupled with an avid sprouting ability.

- Cambium (C) - well protected in the larger DBH's. Small to mid-range DBH's offer poor to fair protection to cambium with thinner bark and less surface area.

- Roots (R) - develop deep taproots and intricate systems of lateral roots which may approach the soil surface and grow downhill, eventually emerging from the soil where they form burls that produce sprouts (Burns 1990)

- Leaves and Needles (LN) - known for its aggressive sprouting abilities if its axillary buds are not completely burned

\section{Red Alder (Alnus rubra)}

Red alder is not known for its resilience to fire, but does have an avid stump sprouting ability identified on younger cut stumps (Burns 1990).

- Cambium (C) - thin and susceptible to the smallest of ground fires near its base

- Roots (R) - forms extensive, fibrous root systems within approximately $1-1.5$ feet from the surface of the ground (Burns 1990)

- Leaves and Needles (LN) - known for its sprouting abilities if its axillary buds are not completely burned

\section{California Bay (Umbellularia californica)}

California bay is known for poor resilience to fire. Due to its thin bark, the tree is easily top-killed by fire but sprouts rapidly (Burns 1990). 
- Cambium (C) - thin and susceptible to the smallest of ground fires near its base

- Roots (R) - "The root system of California-laurel has been described as fleshy, deep, and widespreading (49). Several exceptions have been noted, however. Root wads of windthrown trees from alluvial soil in southern Oregon were limited in extent and without a prominent taproot (50). Root systems of seedlings and young trees exposed near Berkeley, CA, had relatively shallow root systems, as did some fallen older trees (28)(Burns 1990).”

- Leaves and Needles (LN) - known for its sprouting abilities if its axillary buds are not completely burned

\section{Pacific Madrone (Arbutus menziesii)}

Fire is a major damaging agent to the thin-barked Pacific madrone. Even the thicker bark at the base of older trees offers little shielding capability. Seedlings, sprouts, and trees all die back to the root crown after fire but rarely are killed (Burns 1990).

- Cambium (C) - thin and susceptible to the smallest of ground fires near its base

- Roots (R) - "Two- to 5-year-old madrone seedlings, growing in partial shade, showed large variation in root pattern and length. Some seedlings had a curving, twisting, primary root with moderately extensive lateral development, and others had moderately twisted primary roots just below ground line that straightened and grew downward for about 23 cm (9 in) (Burns 1990).”

- Leaves and Needles (LN) - known for its sprouting abilities if its axillary buds are not completely burned 


\section{Big Leaf Maple (Acer macrophyllum)}

Big leaf maple root systems are known for fair resilience to fire especially in the larger diameter classes coupled with avid sprouting ability seen on cut stumps.

- Cambium (C) - thin and susceptible to the smallest of ground fires near its base

- Roots (R) - shallow and wide spreading root system

- Leaves and Needles (LN) - known for its sprouting abilities if its axillary buds are not completely burned

\section{Douglas-fir (Pseudotsuga menziesii)}

When crown fires occur, Douglas-fir stands of all ages are at high mortality risk. "The thick bark of older Douglas-fir, however, make this species fairly resistant to ground fires. The thick corky bark of its lower boles and main roots, combined with its capacity to form adventitious roots, are the main adaptations that have enabled Douglasfir to survive less fire-resistant associates and to remain a dominant element in western forests (Burns 1990).”

- Cambium (C) - thick bark in larger diameters provides good protection; small to mid-range diameters lack substantial protection from fire related to reduced bark thickness and thereby surface area

- Roots (R) - “Although Douglas-fir is potentially a deep-rooting species, its root morphology varies according to the nature of the soil. In the absence of obstructions, Douglas-fir initially forms a tap root that grows rapidly during the first few years. In deep soils (69 to $135 \mathrm{~cm}, 27$ to 53 in), it was found that tap roots grew to about 50 percent of their final depth in 3 to 5 years, and to 90 
percent in 6 to 8 years; however, boulders or bedrock close to the soil surface result in quick proliferation of the original tap root. Plate-like root systems develop when Douglas-fir grows in shallow soils or soils with a high water table. Main lateral branches develop during the first or second growing season as branches of the tap root. These structural roots tend to grow obliquely into deeper soil layers and contribute to anchoring a tree. The majority of roots in the surface soil are long rope-like laterals of secondary and tertiary origin. Fine roots, those less than $0.5 \mathrm{~cm}$ (0.2 in) in diameter, develop mostly from smaller lateral roots and are concentrated in the upper $20 \mathrm{~cm}$ (8 in) of soil (29). Fine roots have a short life-span, ranging in general from a few days to several weeks (Burns 1990).”

- Leaves and Needles (LN) - not a sprouting species and clearly susceptible to mortality relating to different levels of crown loss across diameters

\section{Monterey Pine (Pinus radiata)}

Fire is a particular hazard to young, thin-barked Monterey pine trees, and can be disastrous in dense plantations where persistent lower limbs become festooned with dead needles. This results in an ideal situation for crowning fires (Burns 1990).

- Cambium (C) - thick bark in larger diameters provides good protection; small to mid-range diameters lack substantial protection from fire related to reduced bark thickness

- Roots (R) - "After age 5, the roots of pine seedlings grow downward as far as soil depth or the clay layer permit. Main support roots, however, develop in the top $61 \mathrm{~cm}$ (24 in), even in deeper soils (23). Studies at Monterey and Cambria 


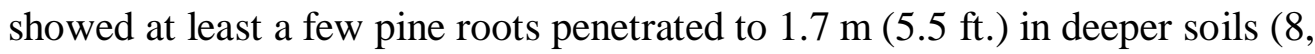
10). The root system becomes extensive laterally and roots of mature pines extend from 9 to $12 \mathrm{~m}$ (30 to $39 \mathrm{ft}$.) from the tree (19). Where a layer of organic matter covers the soil, large numbers of small pine roots exploit the layer for moisture and nutrients (Burns 1990).”

- Leaves and Needles (LN) - not a sprouting species and clearly susceptible to mortality relating to different levels of crown loss across diameters

\section{Knobcone Pine (Pinus attenuata)}

Fire is a particular hazard to the knobcone pine tree, respective to its location primarily on ridge tops where fire intensities are normally the greatest.

- Cambium (C) - most diameters lack substantial protection from fire related to reduced bark thickness

- Roots (R) - shallow lateral root system extending to approximately $1-1.5$ feet deep

- Leaves and Needles (LN) - not a sprouting species and clearly susceptible to mortality relating to different levels of crown loss across diameters 


\section{CHAPTER 3}

Methodology

\section{Measuring Mortality Assessment Model Variables}

Based on published literature and professional opinion from foresters familiar with the redwood region, the following key indicators for determining fire-induced tree mortality, including species and DBH, were tested:

- $\quad$ Cambium (C) = Cambium Quadrants Destroyed by Fire (CQDF)

- $\quad$ Roots $(\mathrm{R})=$ Percent of Root System Missing $($ PRSM)

- $\quad$ Leaves and Needles (LN) = Percent Canopy Remaining (PCR)

- $\quad$ Sprouting Species $(\mathrm{LN})=$ Percent Canopy Sprouting $(\mathrm{PCS})$

\section{Cambium Quadrants Destroyed by Fire (CQDF)}

CQDF is a measurement of how many quadrants of cambium per tree are destroyed by wildfire. This measurement was the easiest to evaluate in areas where burn severity was the highest. In these areas, the bark was completely consumed. The difficulty in determining cambial (C) death came when the bark showed minimal scorching, and other outward indicators of severity were minimal. Initially, chipping away at the bark to determine if the cambium was dead or alive was utilized, but this technique proved to be too time-consuming to sample nearly 4,000 trees. After completing sample falling of redwood trees, a gap between the bark and wood became apparent where cambium had been killed. It was found that by "sounding” the tree (a 
practice used by timber fallers to evaluate the integrity of the wood prior to cutting), a difference in sound was perceived between bark, cambium, and wood. A hollow sound suggested the cambium was unattached to the woody bole of the tree and was dead. Solid sound suggested the cambium was attached to the wood and was alive.

To determine cambial death, field crews utilized a rod that was approximately two feet long and two inches in diameter. Starting at the uphill side of the tree below DBH, the crew member would begin sounding the tree with the rod. The crew member would proceed around the circumference of the tree sounding from below DBH to the approximate base of the tree. Once the crew member sounded the specified area, the amount of cambium quadrants destroyed by fire was determined. This was based on the location of solid vs. hollow sounds emitted from the tree upon being struck. A cambium quadrant was considered to be approximately one quarter across the tree's diameter and at least eight inches to a foot tall to be considered one CQDF.

See Figures 3 - 5 for other indications of cambium mortality such as areas of fungus on bark that represent dead cambium underneath the bark, and bark splitting resulting from live cambium expanding to grow over dead areas of cambium. Figure 6 demonstrates how a tree was divided into 4 quadrants of cambium to determine CQDF.

\section{Percent of Root System Missing (PRSM)}

Field crews spent many months evaluating Root (R) damage on trees before they were able to consistently evaluate PRSM by percent. Most coastal species grow roots laterally, with some species known for having significant tap roots. The PRSM evaluation must be made as soon as possible following the completion of the burn and before the first needle drop, which visually obstructs assessment of root damage. Needle 


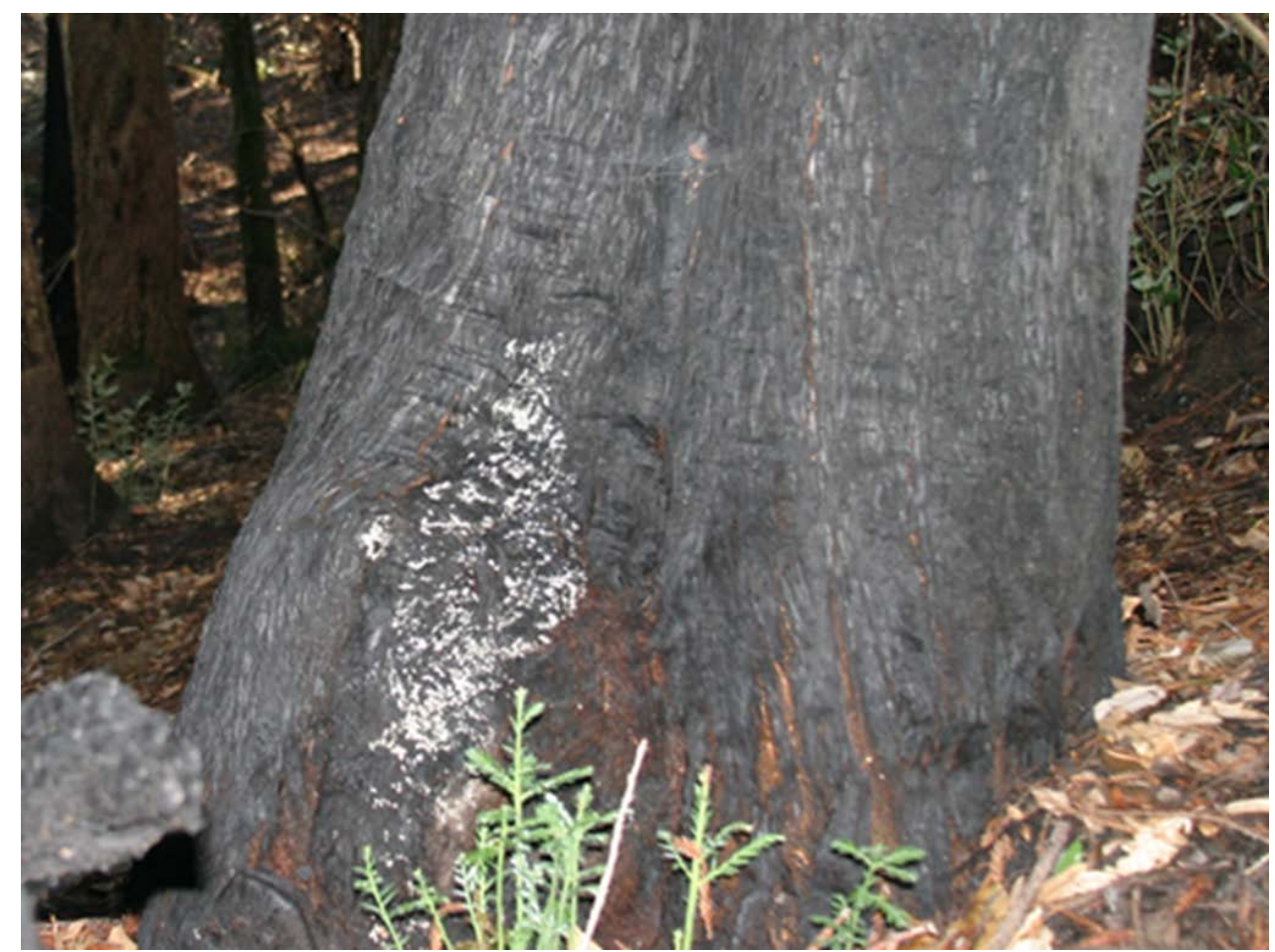

Fig. 3. Fungus on Bark Representing Dead Cambium Underneath Bark.

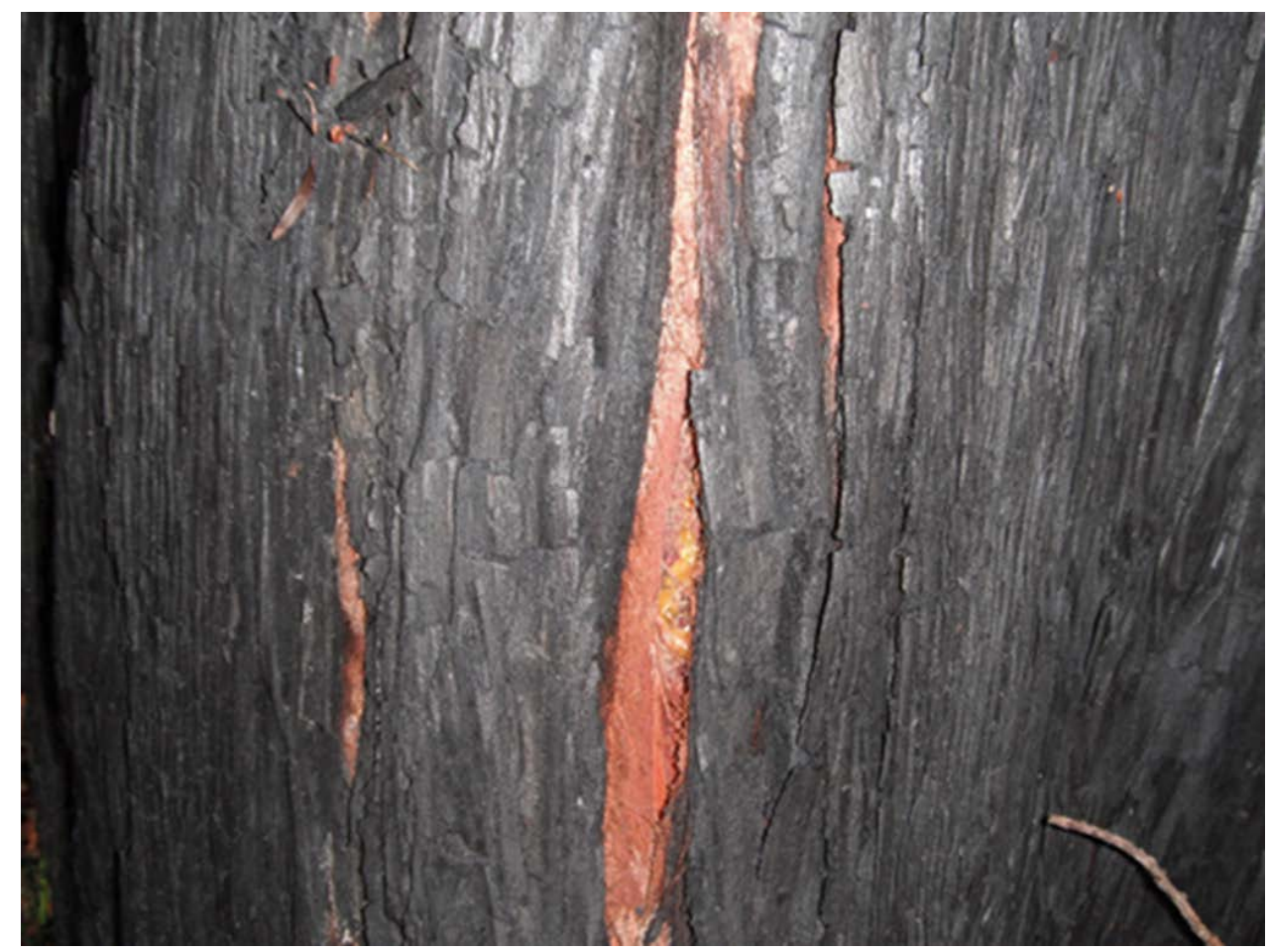

Fig. 4. Evidence of Active Cambial Growth Underneath Bark. 


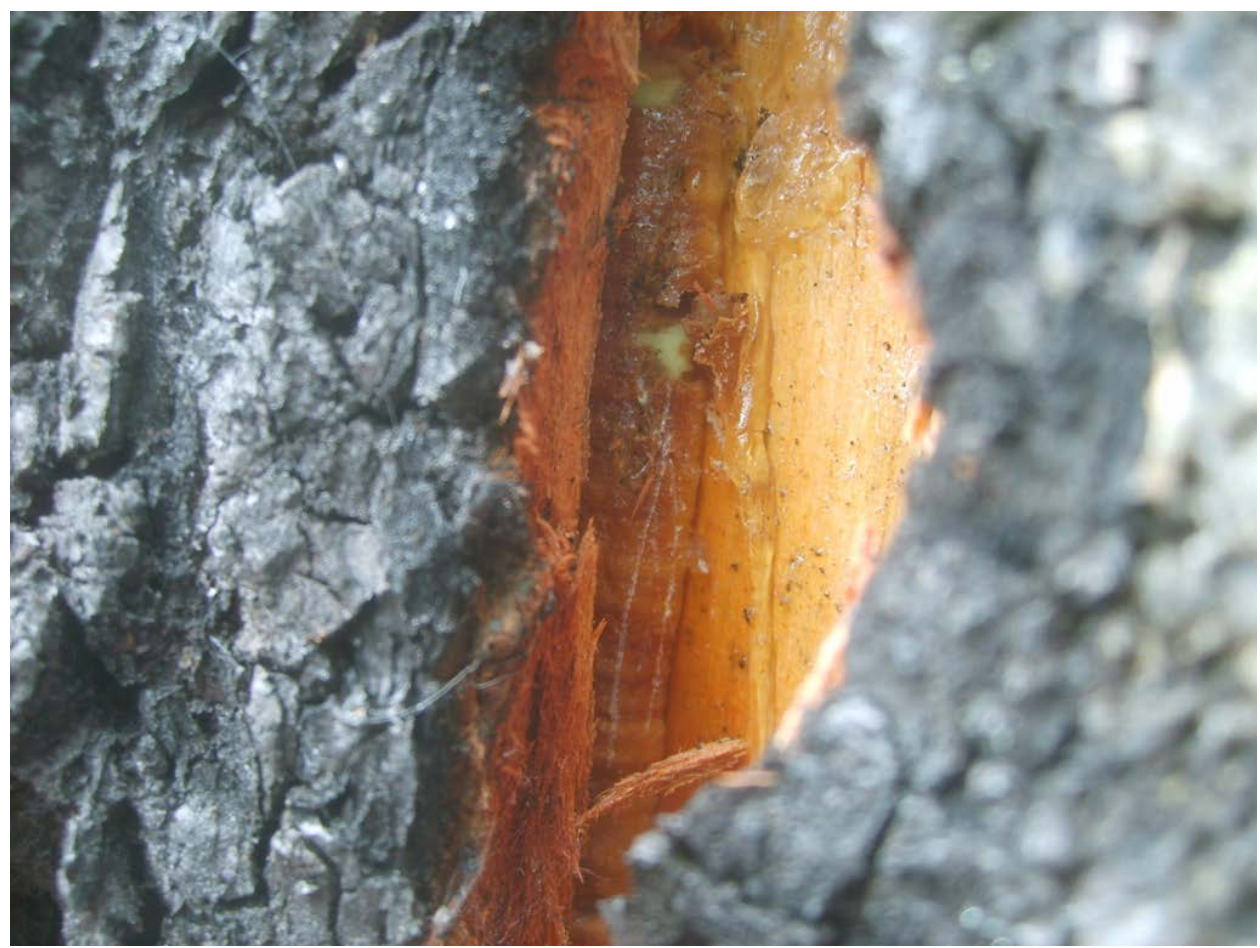

Fig. 5. Cambial Growth in Center of Photo Subsuming Damaged Area on Live Oak.

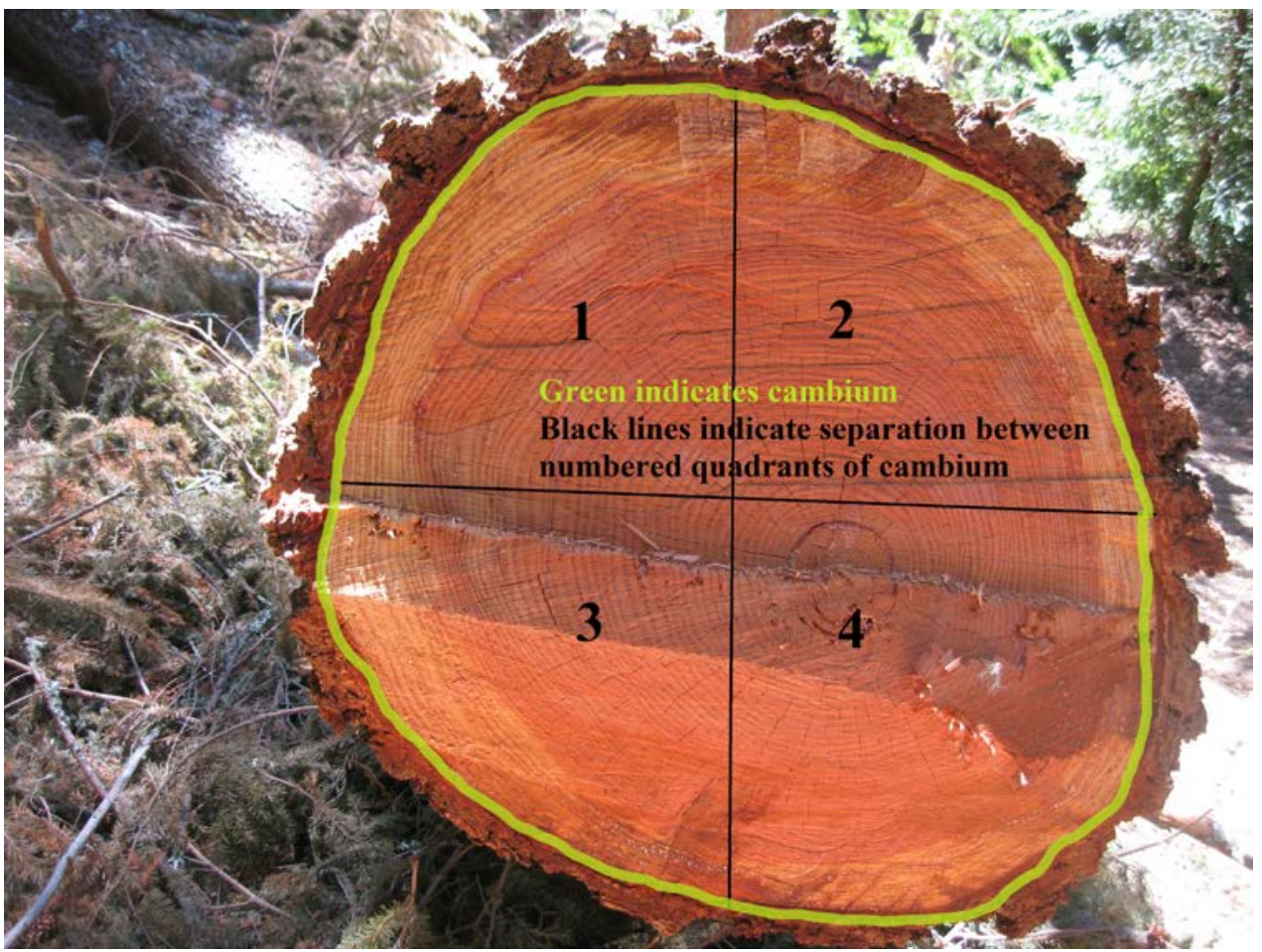

Fig. 6. Method of Cylinder Breakdown to Evaluate Cambium Mortality. 
drop usually occurs during the first significant wind event in the burn area. This is the best time to loosely excavate around the base of the tree when the duff is consumed and multiple root holes are visible to determine PRSM.

To determine the PRSM, field crews utilized a shovel, biltmore stick, and a four foot section of three-eighths inch diameter rebar. Starting at the uphill side of the tree, the crew member would begin looking visually for voids occupied by roots pre-fire extending approximately to the edge of the tree's crown. Large roots were also followed from the base of the tree to the edge of the crown probing with any one of the tools to determine the location of root voids. The crew member would proceed around the entire circumference of the tree evaluating the roots as stated above. The purpose of this activity was to determine whether roots were completely gone or the protective bark structure around them was completely burned off. Following completion of this task, the crew member would determine the percent relationship between total root system (representing 100\%) and the percent of root system missing (PRSM).

Figure 7, below, uses arrows to indicate where lateral root systems begin on a Douglas-fir tree. Illustrated as well in Figure 7, is an example of a basal cavity, a.k.a. “goose pen” formed from previous fires in which the root system was completely destroyed laterally on the exposed side of the tree. Figure 8 shows voids in the soil around an oak tree where roots were completely consumed by wildfire.

\section{Percent Canopy Remaining (PCR)}

PCR is an ocular estimate of green canopy (Leaves and Needles, LN). The crew member must first estimate how far the pre-fire crown extended. With past CFI information on Height-To Crown Base (HTCB) for conifers only, the crew member 


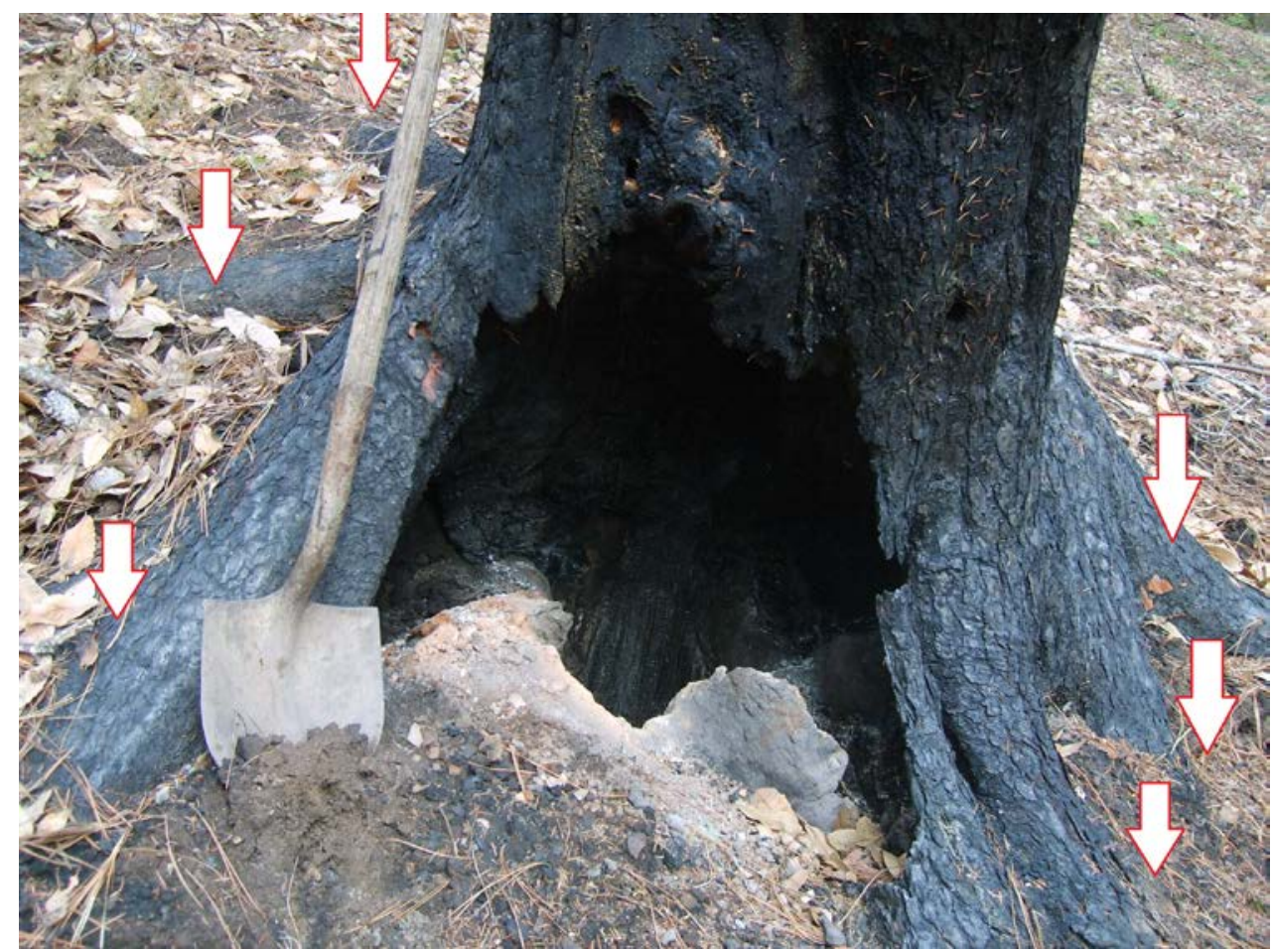

Fig. 7. Arrows Indicating Location of Lateral Root Systems on Douglas-fir.

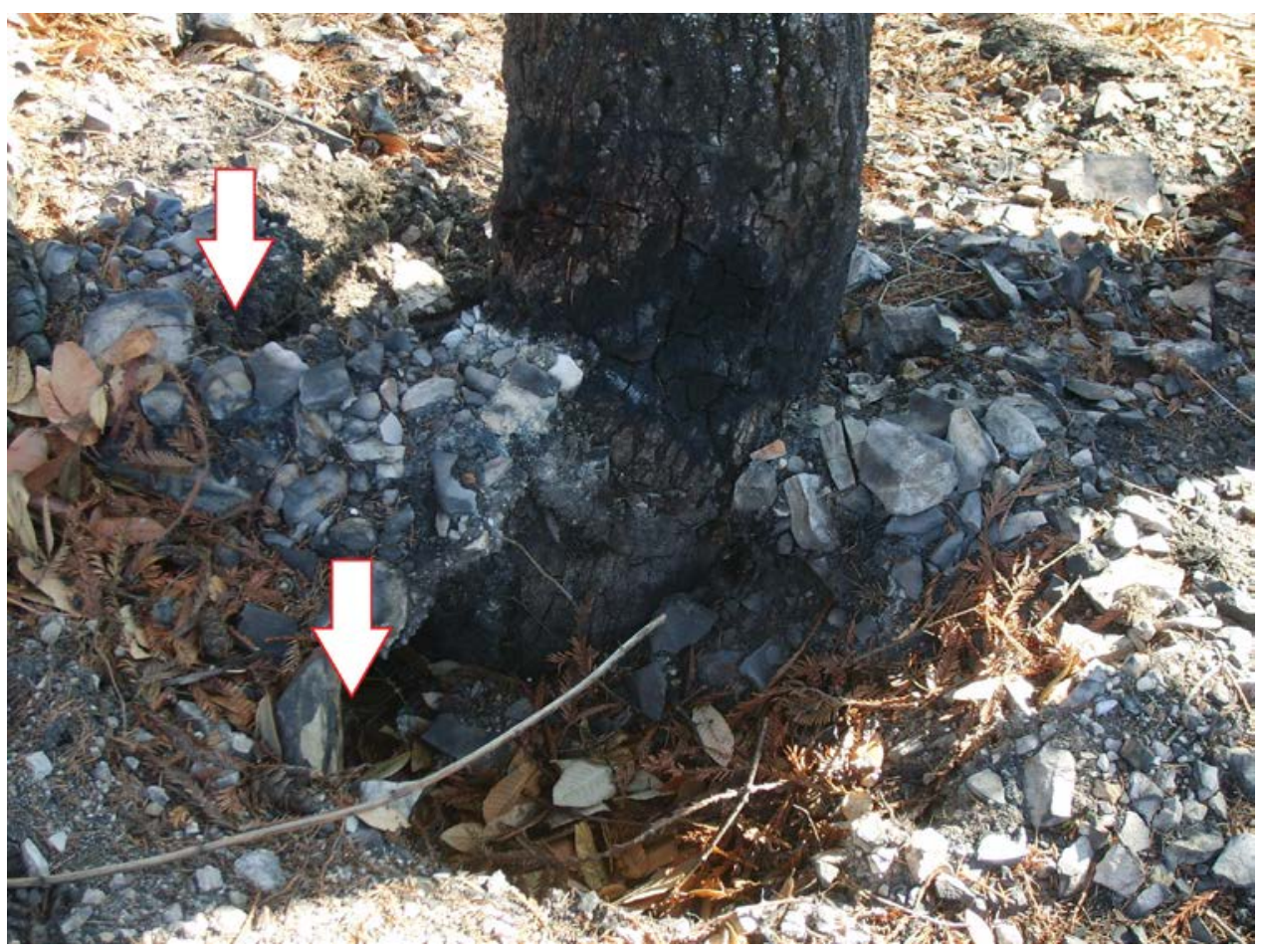

Fig. 8. Arrows Indicating Voids Around Live Oak Tree Where Roots Were Consumed by Wildfire. 
identified the historical location of the tree crown's extent. Then, an ocular estimate was made to estimate PCR. Since no data was recorded on HTCB for hardwoods prior to the fire, estimating where the crown previously extended was re-created by locating the remaining limbs extending down the bole of the tree. This recreated area represents $100 \%$ of the pre-fire crown and the starting point for estimating PCR (Figure 9).

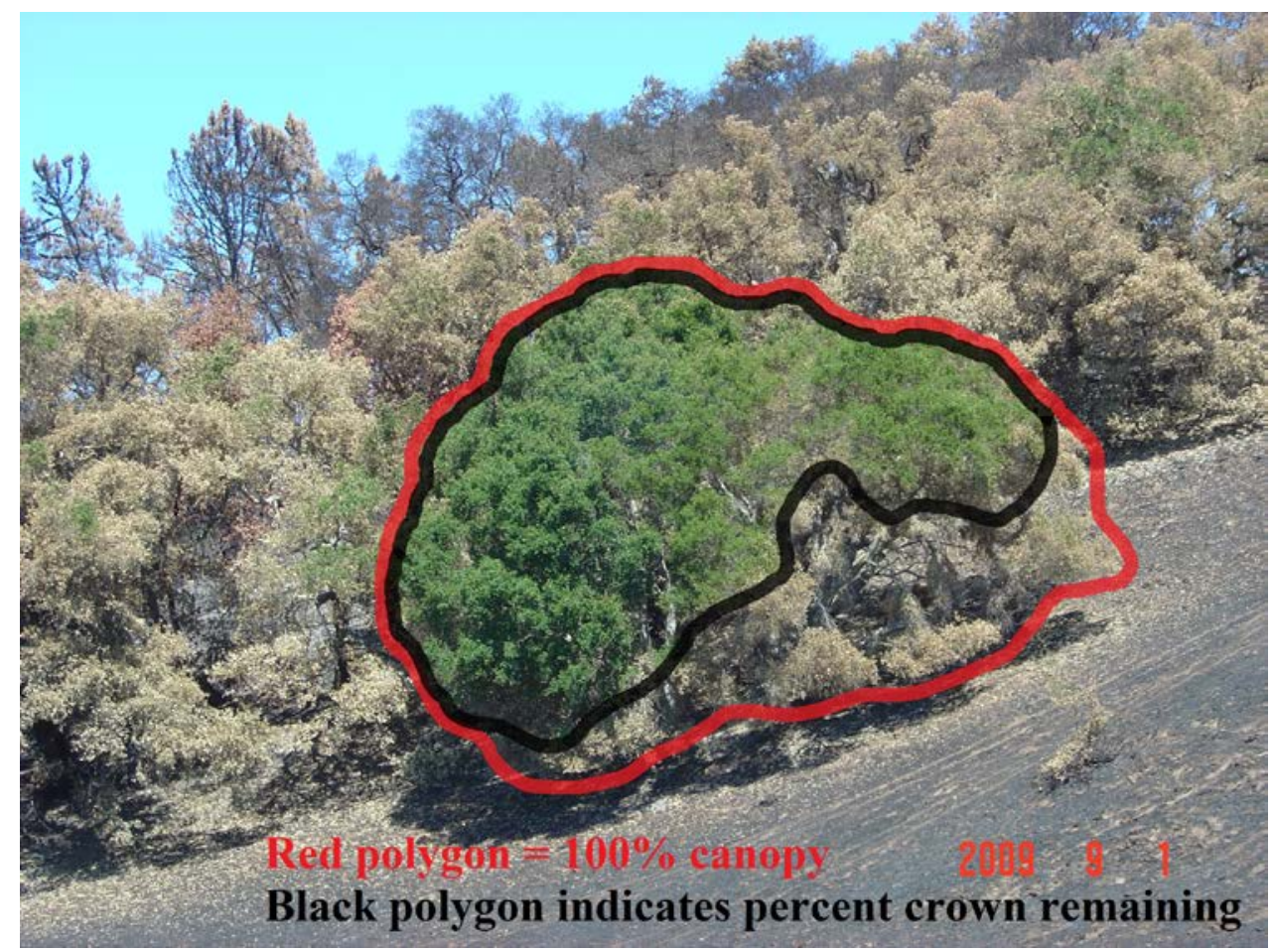

Fig. 9. Two-dimensional Illustration of Percent Crown Remaining Estimation.

\section{Percent Canopy Sprouting (PCS)}

PCS is an ocular estimate of what percentage of limbs within the canopy of the tree, on sprouting species only, are sprouting on areas where Leaves and Needles (LN) were consumed by wildfire. With past CFI information on Height-To Crown Base (HTCB) for conifers only, the crew member identified the historical location of the tree crown's extent. Then, an ocular estimate was made to estimate PCS. Since no data was 
recorded on HTCB for hardwood species pre-fire, estimating where the crown previously extended was recreated by locating remaining limbs extending down the bole of the tree. This recreated area represented $100 \%$ of the pre-fire crown (Figure 10). PCS is related to LN and considered an indicator of axillary bud condition for sprouting species.

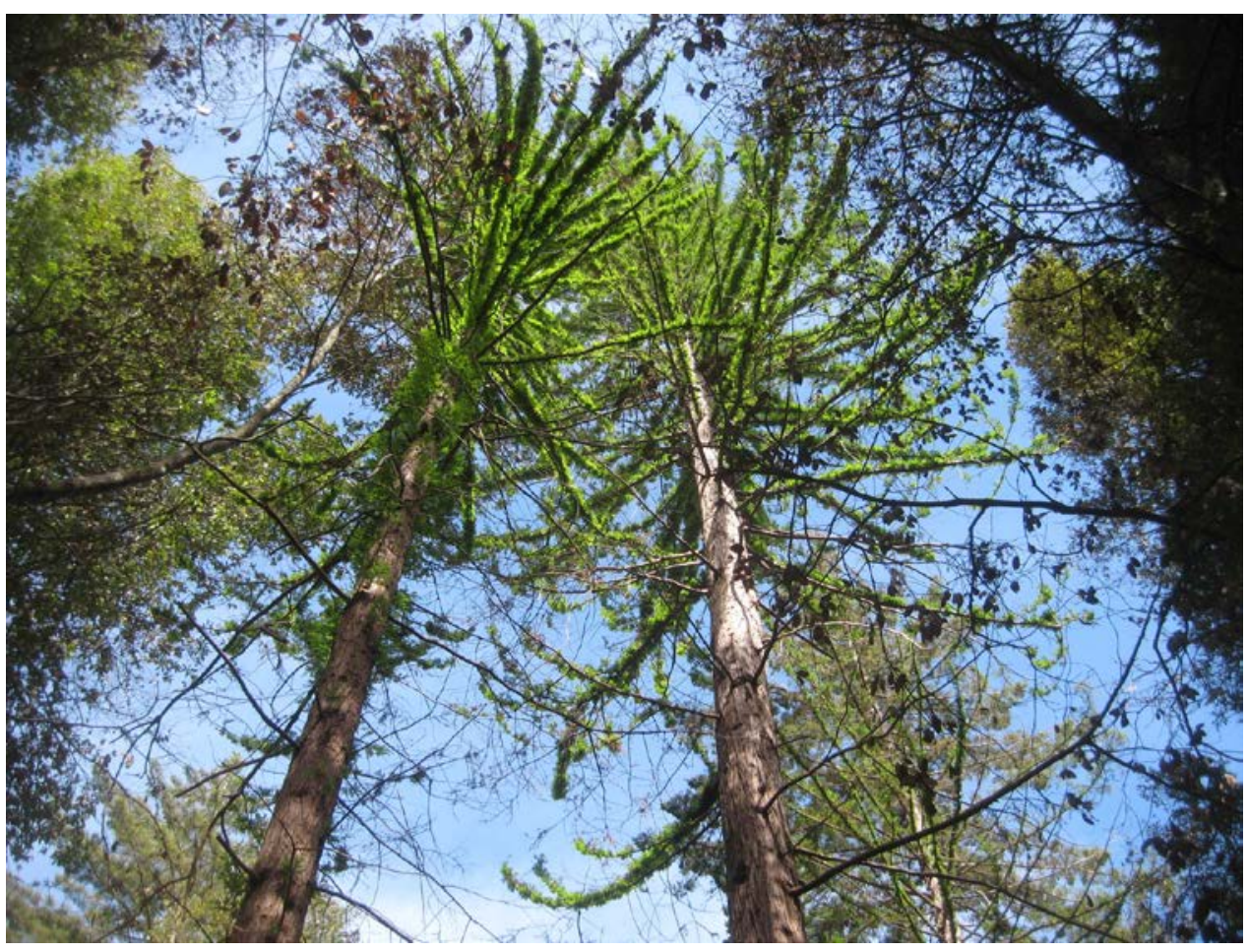

Fig. 10. Illustration of Approximately 100\% Canopy Sprouting on Redwood Following Wildfire.

\section{Mortality Assessment Model Thresholds}

Expected mortality is a function of Species (SP), Diameter at Breast Height (DBH), Percent Canopy Remaining (PCR), Percent Canopy Sprouting (PCS), Percent of Root System Missing (PRSM), and Cambium Quadrants Destroyed by Fire (CQDF):

Mortality $=f($ SP, DBH, PCR, PCS, PRSM, CQDF) 
Based on this mortality relationship, the MA model was first divided into three tables based on species and diameter classes from 1.0 - 8.9 inches, 9.0 - 16.9 inches, and $>17$ inches Diameter at Breast Height (DBH). The purpose of this classification was to separate trees into small, medium and large diameter classes to account for increased fire resilience related to increased surface area from tree size. Therefore, three distinct MA models were created based on the three broad diameter classes that contain variations in mortality thresholds on the model variables. Other differences within each DBH class table $(1.0-8.9$ inches, $9.0-16.9$ inches, and $>17$ inches $)$ are related to physical characteristics among sprouting vs. non sprouting species. Mortality thresholds for nonsprouting species were set slightly higher for PCR than indicated in the literature to account for consideration of PRSM and CQDF. Hood, Ryan, and Wagener suggested a PCR of approximately 50 to $60 \%$ for non-sprouting species, whereas the MA used 60\% to $70 \%$. Additional differences in mortality thresholds among DBH class tables in the MA model were set based on the physical characteristics of each species. For example, red alder in the 9.0 - 16.9 inch DBH class has a CQDF of one, whereas redwood has a CQDF of two because it has much thicker bark than red alder. Tables 3, 4, and 5 show the Mortality Assessment models (MA) as tested. 
Table 3. Mortality Assessment Model for 1 - 8 inch DBH Classes (1.0” - 8.9”)

\begin{tabular}{|l|c|c|c|c|}
\hline \multirow{4}{*}{ Tree Species } & $\begin{array}{c}\text { Percent Canopy } \\
\text { Remaining } \\
\text { PCR }\end{array}$ & $\begin{array}{c}\text { Percent Canopy } \\
\text { Sprouting } \\
\text { PCS }\end{array}$ & $\begin{array}{c}\text { Percent of Root } \\
\text { System Missing } \\
\text { PRSM }\end{array}$ & $\begin{array}{c}\text { Cambium Quadrants } \\
\text { Destroyed by Fire } \\
\text { CQDF }\end{array}$ \\
\hline $\begin{array}{l}\text { Redwood } \\
\text { California nutmeg } \\
\text { Live oak } \\
\text { Tanoak } \\
\text { Red alder } \\
\text { California bay }\end{array}$ & $0 \%$ & $10 \%$ & $33 \%$ & 1 \\
\cline { 2 - 5 } $\begin{array}{l}\text { Pacific madrone } \\
\text { Big leaf maple } \\
\text { Douglas-fir } \\
\text { Monterey pine }\end{array}$ & $0 \%$ & $10 \%$ & $33 \%$ & 1 \\
\cline { 2 - 5 } Knobcone pine & $0 \%$ & $10 \%$ & $33 \%$ & 1 \\
\cline { 2 - 5 } & $0 \%$ & $10 \%$ & $33 \%$ & 1 \\
\cline { 2 - 5 } & $0 \%$ & $10 \%$ & $33 \%$ & 1 \\
\cline { 2 - 5 } & $0 \%$ & $10 \%$ & $33 \%$ & 1 \\
\cline { 2 - 5 } & $70 \%$ & $10 \%$ & $33 \%$ & 1 \\
\hline
\end{tabular}

Table 4. Mortality Assessment Model for 9 - 16 inch DBH Classes (9.0” - 16.9”)

\begin{tabular}{|l|c|c|c|c|}
\hline \multirow{2}{*}{ Tree Species } & $\begin{array}{c}\text { Percent Canopy } \\
\text { Remaining } \\
\text { PCR }\end{array}$ & $\begin{array}{c}\text { Percent Canopy } \\
\text { Sprouting } \\
\text { PCS }\end{array}$ & $\begin{array}{c}\text { Percent of Root } \\
\text { System Missing } \\
\text { PRSM }\end{array}$ & $\begin{array}{c}\text { Cambium Quadrants } \\
\text { Destroyed by Fire } \\
\text { CQDF }\end{array}$ \\
\hline \multirow{2}{*}{$\begin{array}{l}\text { Redwood } \\
\text { California nutmeg } \\
\text { Live oak }\end{array}$} & $0 \%$ & $5 \%$ & $66 \%$ & 2 \\
\cline { 2 - 5 } Tanoak & $0 \%$ & $5 \%$ & $50 \%$ & 2 \\
\cline { 2 - 5 } $\begin{array}{l}\text { Red alder } \\
\text { California bay }\end{array}$ & $0 \%$ & $5 \%$ & $66 \%$ & 2 \\
\hline $\begin{array}{l}\text { Pacific madrone } \\
\text { Big leaf maple } \\
\text { Douglas-fir }\end{array}$ & $0 \%$ & $5 \%$ & $66 \%$ & 2 \\
\cline { 2 - 5 } $\begin{array}{l}\text { Monterey pine } \\
\text { Knobcone pine }\end{array}$ & $0 \%$ & $5 \%$ & $50 \%$ & 2 \\
\cline { 2 - 5 } & $0 \%$ & $5 \%$ & $50 \%$ & 2 \\
\cline { 2 - 5 } & $0 \%$ & $5 \%$ & $50 \%$ & 1 \\
\cline { 2 - 5 } & $60 \%$ & N/A & $33 \%$ & 1 \\
\hline
\end{tabular}


Table 5. Mortality Assessment Model for $>17.0$ inch DBH Classes ( $>17.0$ ”)

\begin{tabular}{|c|c|c|c|c|}
\hline Tree Species & \begin{tabular}{|} 
Percent Canopy \\
Remaining \\
PCR
\end{tabular} & $\begin{array}{c}\text { Percent Canopy } \\
\text { Sprouting } \\
\text { PCS }\end{array}$ & $\begin{array}{c}\text { Percent of Root } \\
\text { System Missing } \\
\text { PRSM }\end{array}$ & $\begin{array}{c}\text { Cambium Quadrants } \\
\text { Destroyed by Fire } \\
\text { CQDF }\end{array}$ \\
\hline \multirow{3}{*}{$\begin{array}{l}\text { Redwood } \\
\text { California nutmeg } \\
\text { Live oak }\end{array}$} & $0 \%$ & $0 \%$ & $66 \%$ & 3 \\
\hline & $0 \%$ & $0 \%$ & $50 \%$ & 2 \\
\hline & $0 \%$ & $0 \%$ & $66 \%$ & 3 \\
\hline \multirow{2}{*}{$\begin{array}{l}\text { Tanoak } \\
\text { Red alder }\end{array}$} & $0 \%$ & $0 \%$ & $66 \%$ & 3 \\
\hline & $0 \%$ & $0 \%$ & $50 \%$ & 2 \\
\hline \multirow{3}{*}{$\begin{array}{l}\text { California bay } \\
\text { Pacific madrone } \\
\text { Big leaf maple }\end{array}$} & $0 \%$ & $0 \%$ & $50 \%$ & 2 \\
\hline & $0 \%$ & $0 \%$ & $50 \%$ & 2 \\
\hline & $0 \%$ & $0 \%$ & $50 \%$ & 2 \\
\hline Douglas-fir & $60 \%$ & N/A & $33 \%$ & 2 \\
\hline \multirow{2}{*}{$\begin{array}{l}\text { Monterey pine } \\
\text { Knobcone pine }\end{array}$} & $60 \%$ & N/A & $33 \%$ & 2 \\
\hline & $60 \%$ & N/A & $33 \%$ & 2 \\
\hline
\end{tabular}

As an example, evaluating live oak in Table 5, the tree was coded dead if:

- $\quad$ PCR = 0\%;

- $\quad$ and a PCS = 0\%;

- $\quad$ and a PRSM > 66\%;

- $\quad$ and $\mathrm{CQDF}>3$.

It is important to acknowledge that these MA model estimates involve a degree of subjectivity. Therefore if there was a doubt as to what the estimates of any of the MA model variables were, then the greater number was used. For example, if the crew was deciding whether there were two or three quadrants of cambium dead they would always choose three. The result should be an overestimation, to some degree, of mortality.

\section{Testing the Mortality Assessment Model Using the Continuous Forest Inventory System}

The Swanton Pacific Ranch (SPR) Continuous Forest Inventory (CFI) was previously measured in 2003 and 2008. Pre-fire CFI data was collected in late 2008 from 
the Little Creek drainage and in 2003 for the remainder of the NTMP area spanning Little Creek, Winter Creek, and Archibald Creek watersheds. Diameter at Breast Height (DBH) measurements in the Winter Creek and Archibald Creek watersheds from 2003 CFI data were projected to 2008 , utilizing a growth rate of $2 \%$. The purpose of this analysis was to project DBH growth from 2003 to the approximate time of the Lockheed Fire. DBH growth projections from 2003 to 2008 were confirmed by comparing actual growth in Little Creek from 1997 to 2008 to insure relative accuracy.

To begin the analysis, field crews located the plot center for each one-fifth acre fixed plot. Each tree within the plot was numbered consecutively and evaluated in detail, moving clockwise with tree number one located at due north. Crew members then assessed the Percent Canopy Remaining (PCR), Percent Canopy Sprouting (PCS), Percent of Root System Missing (PRSM), and Cambium Quadrants Destroyed by Fire (CQDF). Based on the application of the MA model each tree was coded dead (D) or live (L). Figure 11 shows a photo of a CFI plot taken about three to four months following the Lockheed Fire.

The Mortality Assessment model was completed in 2009, three to four months following the Lockheed Fire. In 2010, several areas in the North Fork of Little Creek and Winter Creek watersheds were salvage logged. The South Fork of Little Creek was harvested under the NTMP in 2011. The original sample size of the 2009 MA was approximately 4,000 trees. A number of these trees were removed or considered collateral damage due to harvesting activities, and therefore were not available for further re-evaluation. There are still 2,877 trees associated with 82 CFI plots that remain under ongoing study to assess the accuracy of the MA (Table 6). The CFI provided information 


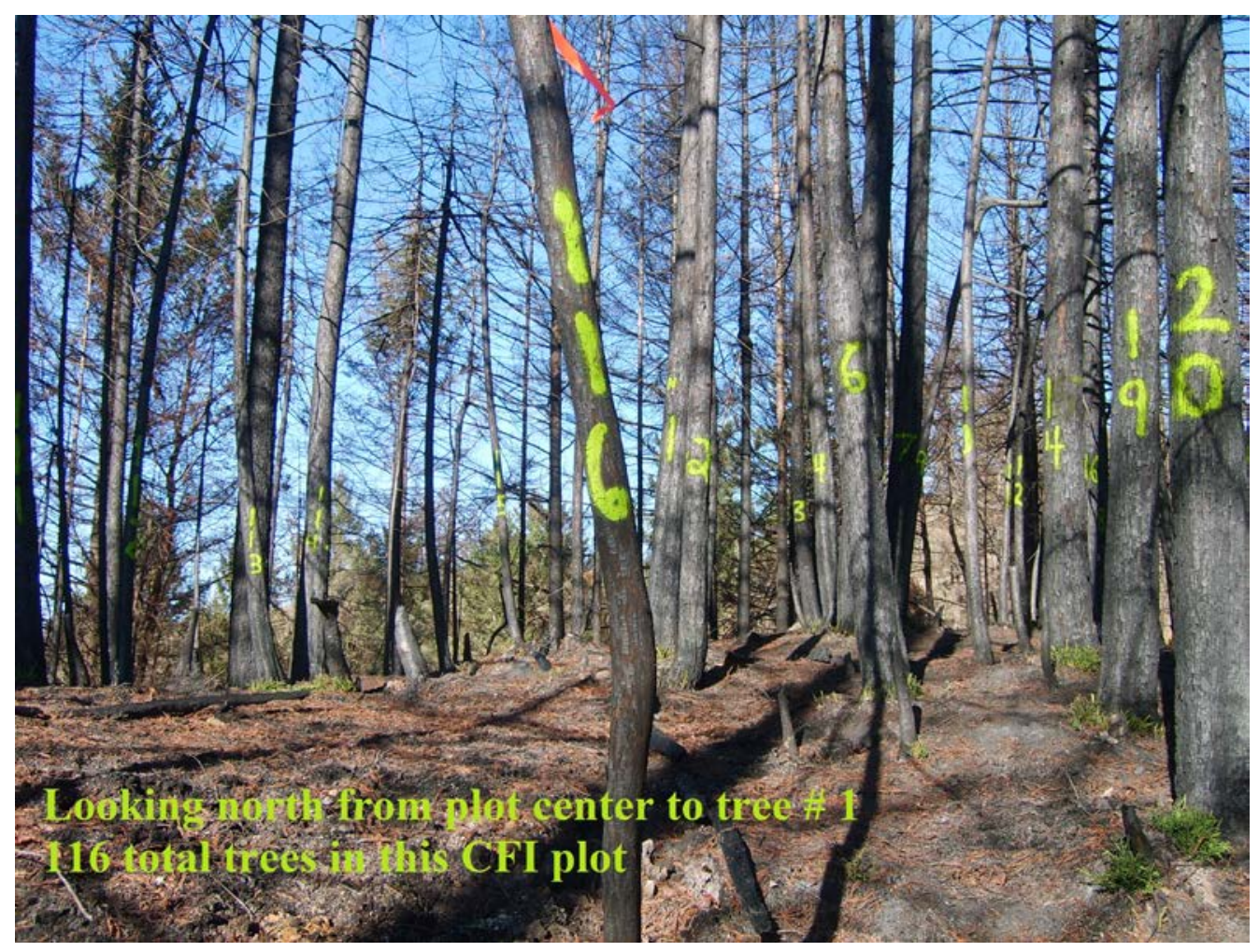

Fig. 11. Picture of Re-measured CFI Plot Post-fire.

Table 6. Sample Size by Tree Species Based on Diameter at Breast Height (DBH)

\begin{tabular}{|l|c|c|c|}
\hline Tree Spe cies & $\mathbf{1}$ - 8" DBH & 9 - 16" DBH & $>\mathbf{1 7}$ " DBH \\
\hline Redwood & 470 & 223 & 271 \\
\cline { 2 - 4 } California nutmeg & 12 & 5 & 3 \\
\cline { 2 - 4 } Live oak & 207 & 150 & 74 \\
\cline { 2 - 4 } Tanoak & 302 & 181 & 66 \\
\cline { 2 - 4 } $\begin{array}{l}\text { Red alder } \\
\text { California bay } \\
\text { Pacific madrone }\end{array}$ & 8 & 0 & 7 \\
\cline { 2 - 4 } $\begin{array}{l}\text { Big leaf maple } \\
\text { Douglas-fir } \\
\text { Monterey pine }\end{array}$ & 119 & 50 & 9 \\
\cline { 2 - 4 } Knobcone pine & 61 & 15 & 6 \\
\cline { 2 - 4 } & 2 & 0 & 0 \\
\cline { 2 - 4 } & 290 & 122 & 180 \\
\hline \multirow{2}{*}{ Total n=2877 } & 17 & 19 & 2 \\
\hline
\end{tabular}


on the condition of each tree from $1-6$ years prior to the Lockheed Fire making it an effective system to test the Mortality Assessment model.

\section{Accuracy of the Mortality Assessment Model}

The Mortality Assessment (MA) model was re-evaluated from May to June of 2010, and July to August of 2011 to determine the MA model accuracy. Each of the 2,877 trees within the 82 CFI plots were re-visited by the field crews to check if the 2009 MA model predictions of dead (d) or live (l) were correct or not.

See Table 7 below for a summary table excerpt of redwood comparing the outcomes between the MA 2009, and the MA re-evaluations between 2010 and 2011. Index row \#284 in Table 7, shows a 14.2” DBH redwood that was considered dead (d) by the MA in 2009. It was still living (l), however, after the MA re-evaluation periods in 2010 and 2011. This scenario demonstrates how the outcome of the MA can drive the Sustainability Analysis (SA) to underestimate the actual forest volume. If the same redwood was considered live (l) by the MA in 2009 but dead (d) after the MA reevaluation periods in 2010 and 2011, the SA would be overestimating the actual forest volume. More details on this relationship are found in Chapter 4 Results and Discussion, “Living Errors and Dead Errors”.

\section{Sustainability Analysis and Setting Mortality Assessment Model Thresholds}

The Mortality Assessment (MA) model was created to determine whether a tree would likely live or die following a wildfire. Creating a long-term forecast for forest growth based on a post-fire evaluation that suggests a tree will live when, in fact, it ultimately dies, could have far-reaching effects on long-term Sustainability Analysis (SA) 
Table 7. Summary Table Excerpt for Redwood Displaying 3 Years of MA Evaluation ( $\mathrm{d}=$ dead, $\mathrm{l}=$ live $)$

\begin{tabular}{|c|c|c|c|c|c|c|c|c|c|c|c|}
\hline Index & tree \# & species & DBH & MA & MA - Re-ev. & MA - Re-ev. & MA Eval & veg type & plot \# & Northing & Easting \\
\hline & & & & 2009 & 2010 & 2011 & Cor? & & & & \\
\hline 142 & 13 & rw & 18.8 & 1 & 1 & 1 & yes & DFHW & 150 & 7000 & 12500 \\
\hline 269 & 2 & $\mathrm{mw}$ & 30.5 & I & 1 & 1 & yes & DF & 139 & 8000 & 12500 \\
\hline 281 & 1 & rw & 26.2 & 1 & 1 & 1 & yes & RWIV & 140 & 8000 & 13000 \\
\hline 282 & 2 & $\mathrm{rw}$ & 9.2 & d & d & d & yes & RWIV & 140 & 8000 & 13000 \\
\hline 283 & 3 & $\mathrm{mw}$ & 4.2 & d & d & d & yes & RWIV & 140 & 8000 & 13000 \\
\hline 284 & 4 & $\mathrm{rw}$ & 14.2 & d & 1 & 1 & no & RWIV & 140 & 8000 & 13000 \\
\hline 297 & 17 & rw & 18.1 & 1 & 1 & 1 & yes & RWIV & 140 & 8000 & 13000 \\
\hline 298 & 18 & $\mathrm{rw}$ & 4.6 & d & d & d & yes & RWIV & 140 & 8000 & 13000 \\
\hline 299 & 19 & $\mathrm{rw}$ & 1.7 & d & d & d & yes & RWIV & 140 & 8000 & 13000 \\
\hline 301 & 21 & $\mathrm{rw}$ & 15.9 & 1 & 1 & 1 & yes & RWIV & 140 & 8000 & 13000 \\
\hline 303 & 23 & $\mathrm{rw}$ & 9.7 & d & $d$ & $d$ & yes & RWIV & 140 & 8000 & 13000 \\
\hline 309 & 29 & $\mathrm{rw}$ & 4.9 & d & d & d & yes & RWIV & 140 & 8000 & 13000 \\
\hline 312 & 32 & $\mathrm{rw}$ & 1.3 & d & d & d & yes & RWIV & 140 & 8000 & 13000 \\
\hline 317 & 37 & $\mathrm{rw}$ & 4.4 & d & d & d & yes & RWIV & 140 & 8000 & 13000 \\
\hline 318 & 38 & rw & 13.7 & 1 & 1 & 1 & yes & RWIV & 140 & 8000 & 13000 \\
\hline 322 & 42 & nw & 13.8 & 1 & 1 & 1 & yes & RWIV & 140 & 8000 & 13000 \\
\hline 324 & 44 & rw & 13.5 & 1 & 1 & 1 & yes & RWIV & 140 & 8000 & 13000 \\
\hline 326 & 46 & $\mathrm{rw}$ & 15.5 & 1 & 1 & 1 & yes & RWIV & 140 & 8000 & 13000 \\
\hline
\end{tabular}

predictions. Underestimating the mortality prediction would jeopardize the sustained yield prediction. In such a case, harvest rate would be predicted to be greater than can be sustained in reality. The State of California Forest Practices Act also requires that a SA be accurate within a certain statistical tolerance. As mentioned earlier the model was applied in a conservative manner for this purpose. In essence, when the MA suggests a tree is going to die, there is still a slight chance that it could live, and vice versa. The MA model was designed and applied in a manner to make underestimating mortality less likely, i.e., slightly overestimating mortality.

A redwood that has a $\mathrm{DBH}$ of at least 17" is expected to die based on the MA model having the following characteristics: $(\mathrm{PCR}=0 \%)$ and $(\mathrm{PCS}=0 \%)$ and $(\mathrm{PRSM}>$ $66 \%)$ and (CQDF>3). The chance for survival still exists, however slight, because the assessment is clearly subject to error. As a result, subsequent SA predictions will have a 
somewhat, but unknown, lower probability of overestimating live forest inventory. Understanding this relationship between the MA and SA is very important when the financial and regulatory implications of forest management are considered. For example, a forestry consultant tells a client that they have 500,000 board feet (BF) to harvest, but in reality there is only $250,000 \mathrm{BF}$. That lower available volume for harvest may ultimately make the harvest uneconomical and the Sustainability Analysis (SA) inaccurate. The forester could potentially be deemed negligent by the review agencies, resulting in possible legal action against the forester's license. 


\section{CHAPTER 4}

Results and Discussion

\section{General Results and Discussion for the Mortality Assessment Model}

Tables 8, 9 and 10 display the general results on the accuracy of the Mortality Assessment (MA) model, first implemented in Fall 2009. The MA was re-evaluated in Spring 2010 and 2011, and was confirmed 89.3\% accurate overall for all tree species across all diameter classes. The accuracy for specific diameter classes can be further broken down to the following weighted averages:

- $88.7 \%$ for all species in the $1-8$ inch DBH Class (1.0”-8.9”)

- $88.1 \%$ for all species in the $9-16$ inch DBH Class (9.0”-16.9”)

- $92.4 \%$ for all species in the $>17$ inch DBH Class (>17.0”)

\section{Living Errors and Dead Errors}

The Problem Description is reiterated here to provide background information for discussing "living errors” and “dead errors":

“The Non-Industrial Timber Management Plan (NTMP) and Sustainability Analysis (SA) were based upon the Continuous Forest Inventory (CFI) data prior to the Lockheed Fire of 2009. The NTMP will be invalidated by the State if the NTMP and SA are not amended to reflect the changes in forest inventory due to the Lockheed Fire. The CFI plots in the burn area needed to be re-evaluated immediately post-fire to determine what trees would live or die. Scheduled 
Table 8. Percent Accuracy of the Mortality Assessment Model: $1.0-8.9$ inch DBH

\begin{tabular}{|l|c|c|}
\hline Tree Species & Percent Accuracy & Sample Size \\
\hline Redwood & $90.4 \%$ & 470 \\
\cline { 2 - 3 } California nutmeg & $58.3 \%$ & 12 \\
\cline { 2 - 3 } Live oak & $85.9 \%$ & 207 \\
\cline { 2 - 3 } Tanoak & $88.0 \%$ & 302 \\
\cline { 2 - 3 } Red alder & $62.5 \%$ & 8 \\
\cline { 2 - 3 } California bay & $84.0 \%$ & 119 \\
\cline { 2 - 3 } $\begin{array}{l}\text { Pacific madrone } \\
\text { Big leaf maple } \\
\text { Douglas-fir }\end{array}$ & $77.0 \%$ & 61 \\
\cline { 2 - 3 } Monterey pine & $0.0 \%$ & 2 \\
\cline { 2 - 3 } Knobcone pine & $96.2 \%$ & 17 \\
\cline { 2 - 3 } & $82.3 \%$ & 1488 \\
\hline Weighted ave rage & $\mathbf{8 8 . 0} \%$ & 290 \\
\hline
\end{tabular}

Table 9. Percent Accuracy of the Mortality Assessment Model: $9.0-16.9$ inch DBH

\begin{tabular}{|l|c|c|}
\hline Tree Species & Percent accuracy & Sample size \\
\hline Redwood & $93.2 \%$ & 223 \\
\cline { 2 - 3 } California nutmeg & $80.0 \%$ & 5 \\
\cline { 2 - 3 } Live oak & $88.0 \%$ & 150 \\
\cline { 2 - 3 } Tanoak & $83.9 \%$ & 181 \\
\cline { 2 - 3 } Red alder & $0.0 \%$ & 0 \\
\cline { 2 - 3 } $\begin{array}{l}\text { California bay } \\
\text { Pacific madrone }\end{array}$ & $66.0 \%$ & 50 \\
\cline { 2 - 3 } Big leaf maple & $73.0 \%$ & 15 \\
\cline { 2 - 3 } Douglas-fir & $0.0 \%$ & 0 \\
\cline { 2 - 3 } Monterey pine & $97.5 \%$ & 122 \\
\cline { 2 - 3 } Knobcone pine & $78.9 \%$ & 19 \\
\hline Weighted ave rage & $\mathbf{8 8 . 1 \%}$ & 768 \\
\hline
\end{tabular}


Table 10. Percent Accuracy of the Mortality Assessment Model: $>17.0$ inch DBH

\begin{tabular}{|l|c|c|}
\hline Tree Species & Percent accuracy & Sample size \\
\hline Redwood & $97.7 \%$ & 271 \\
\cline { 2 - 3 } California nutmeg & $66.0 \%$ & 3 \\
\cline { 2 - 3 } Live oak & $89.1 \%$ & 74 \\
\cline { 2 - 3 } Tanoak & $95.4 \%$ & 66 \\
\cline { 2 - 3 } Red alder & $28.6 \%$ & 7 \\
\cline { 2 - 3 } California bay \\
\cline { 2 - 3 } $\begin{array}{l}\text { Pacific madrone } \\
\text { Big leaf maple }\end{array}$ & $55.0 \%$ & 9 \\
\cline { 2 - 3 } Douglas-fir & $50.0 \%$ & 6 \\
\cline { 2 - 3 } Monterey pine & $0.0 \%$ & 0 \\
\cline { 2 - 3 } Knobcone pine & $90.5 \%$ & 180 \\
\cline { 2 - 3 } & $100.0 \%$ & 2 \\
\hline Weighted ave rage & $100.0 \%$ & 3 \\
\hline
\end{tabular}

long-term forest management plans depended on that information. A quick and reliable field technique to determine tree mortality is required. This is also the case with any other forestland owner who is faced with predicting the effects of a fire, especially those with regulatory agreements in place."

The CFI system utilized for the Swanton NTMP Sustainability Analysis consists of a systematic grid of 82 one-fifth acre fixed area plots. Volumes from one-fifth acre plots were calculated by totaling the amount of volume based on the amount of trees per plot and multiplying by 5 to obtain forest volume per acre (one-fifth ac. of trees x $5=1$ ac. of trees estimated from the one-fifth acre plot). Larger trees in each plot have significantly more volume than smaller trees. For example, the volume of a 32” diameter tree (approximately 1,000 board feet (BF) x $5=5,000$ BF) can create much more significant error per acre than the volume of a 10" diameter tree (approximately 60 board feet $(\mathrm{BF})$ x $5=300 \mathrm{BF})$. If errors in the MA were occurring more often in larger 
diameter classes, as opposed to smaller diameter classes, the errors in the SA would have much greater reverberations in future forest inventory projections. Larger diameter trees represent a proportionally greater amount of possible error when calculating total forest volumes. Understanding the relationship between the volume of the tree in BF is critical to weighing the significance of a living or dead error.

A "living error" resulted when the Mortality Assessment (MA) model predicted that a tree would die and in fact it lived. This is similar to making a Type II error in statistics where the hypothesis is accepted when it is actually false. The implication to the Sustainability Analysis (SA) of "living errors", if they are not in excessive amounts, is likely to be a conservative estimate of current and predicted forest volume. Underestimating forest volume is almost always better and less detrimental to the SA than overestimating forest volume. One exception to this statement would be that if the volume was so underestimated that it caused harvesting to take more time than expected, inconvenient and expensive delays could occur. Another consideration for underestimating forest volume on the SA, is that future volume projections would be heavily impacted. These compounded errors, due to continual underestimation of forest volume, would not allow the full potential of the forest to be realized from a management standpoint.

A “dead error” resulted when the Mortality Assessment (MA) model predicted that a tree would live, and in fact it died. Dead errors result in underestimating mortality in a manner similar to a Type I error in statistics where one rejects the hypothesis when it is actually true. The implications to the SA in this case are of much greater concern. Consider that larger trees in each plot have significantly more volume than smaller trees. 
For example, the volume of a 32” diameter tree (approximately1,000 board feet (BF) x 5 $=5,000 \mathrm{BF}$ ) can create much more significant error per acre than the volume of a 10" diameter tree (approximately 60 board feet $(\mathrm{BF}) \mathrm{x} 5=300 \mathrm{BF}$ ). If errors in the MA are occurring more often in larger diameter classes, as opposed to smaller diameter classes, the errors in the SA will have much greater reverberations in future forest projections due to a more significant overestimation of forest volume with larger diameter trees.

Overestimating forest volume, due to multiple dead errors in the SA, could result in unintentionally harvesting more volume than the forest can sustain. This can have several adverse impacts for the land and negatively reflect on the decisions made by the "forester of plan". The sustainable harvest levels, as well as associated forest attributes of the land, could be jeopardized for years to come due to overestimating projected long term forest volumes. Legal action by Cal Fire, the lead agency regulating timber harvesting for private lands in California, could be taken against the RPF of plan for negligence based on such incorrect assumptions. Of equal concern is that the error may affect financial returns to the landowner due to miscalculations of forest volume available from the harvest.

To date, the MA model has delivered strong results with close to $90 \%$ accuracy for all species and diameters. The majority of the errors in the MA are Type I, or dead errors. These errors are mostly in lower diameter classes implying that the SA results would slightly overestimate forest volume. Based on the number of these smaller trees and their corresponding volumes, it is expected that these Type I errors would have an insignificant effect on the sustainability analysis. See the Conclusions and Recommendations section for adjustments to the MA model to reduce Type I errors. 


\section{Results of Mortality Assessment Model by Species}

The Mortality Assessment (MA) model was statistically significant for redwood, live oak, tanoak, and Douglas-fir in all diameter classes with two-tailed p values $<0.0001$. The MA was also statistically significant in some diameter classes for California bay (1 8” DBH class), Pacific madrone (1 - 8” DBH class), and Monterey Pine (1 - 8” and 9 16.9” DBH class). The MA was not statistically significant, mostly due to small sample size, for California nutmeg, California bay ( $9-16.9$ ” and $>17.0$ ” DBH class), red alder, Pacific madrone (9 - 16.9” and >17.0” DBH class), big leaf maple, Monterey Pine (>17.0” DBH class) and knobcone pine.

Standard deviation, z-statistic, and p-value are provided where sample size was sufficient to infer a normal distribution. The z-statistic is based on the null hypothesis of a 50\% probability for a tree either living or dying. A summary of the MA model results and statistics by species follow (see Tables $11-28$ ).

\section{Redwood}

Table 11. Redwood Results Following 2 Years of Re-evaluation of the Mortality Assessment Model

\begin{tabular}{|c|c|c|c|c|c|c|c|c|c|}
\hline DBH (in) & $\begin{array}{c}\text { Tree } \\
\text { Species }\end{array}$ & \begin{tabular}{|c|} 
Percent \\
Canopy \\
Remaining \\
PCR
\end{tabular} & $\begin{array}{c}\text { Percent } \\
\text { Canopy } \\
\text { Sprouting } \\
\text { PCS }\end{array}$ & $\begin{array}{c}\text { Percent of } \\
\text { Root } \\
\text { System } \\
\text { Missing } \\
\text { PRSM }\end{array}$ & $\begin{array}{c}\text { Cambium } \\
\text { Quadrants } \\
\text { Destroyed } \\
\text { by Fire } \\
\text { CQDF }\end{array}$ & $\begin{array}{l}\text { Percent } \\
\text { Accuracy }\end{array}$ & $\begin{array}{c}\text { Sample } \\
\text { Size }\end{array}$ & $\begin{array}{c}\text { \# of Trees } \\
\text { Predicted } \\
\text { to Die that } \\
\text { are Still } \\
\text { Living }\end{array}$ & $\begin{array}{c}\text { \# of Trees } \\
\text { Predicted } \\
\text { to Live that } \\
\text { are Dead }\end{array}$ \\
\hline $1.0-8.9$ & Redwood & $0 \%$ & $10 \%$ & $33 \%$ & 1 & $90.4 \%$ & 470 & 12 & 33 \\
\hline $9.0-16.9$ & Redwood & $0 \%$ & $5 \%$ & $66 \%$ & 2 & $93.2 \%$ & 223 & 9 & 6 \\
\hline$>17.0$ & Redwood & $0 \%$ & $0 \%$ & $66 \%$ & 3 & $97.7 \%$ & 271 & 2 & 4 \\
\hline
\end{tabular}


A total of 964 redwood trees were evaluated utilizing the MA. Weighted average for percent accuracy across all diameter classes for redwood was approximately $93 \%$. A total of 66 errors occurred out of 964 MA predictions.

Table 12. Redwood Statistics

\begin{tabular}{|c|c|c|c|c|c|c|c|c|c|}
\hline & Tree & Eval. & Eval. & Standard & \multicolumn{4}{|c|}{ Normal Approximation o.k.? } & Two-tailed \\
\cline { 7 - 9 } DBH" & Species & Correct & Incorrect & Deviation & $\mathbf{n}^{*} \mathbf{p}$ & $\mathbf{n}(\mathbf{1}-\mathbf{p}) \geq \mathbf{5}$ & $\mathbf{n}^{*} \mathbf{p} \geq \mathbf{5}$ ? & $\mathbf{z}$ & P value \\
\hline $1.0-8.9$ & Redwood & 437 & 45 & 0.0230633 & 235 & 235 & yes & -17.5281 & $<0.0001$ \\
\hline $9.0-16.9$ & Redwood & 217 & 15 & 0.0334825 & 111.5 & 111.5 & yes & -12.9242 & $<0.0001$ \\
\hline$>17.0$ & Redwood & 267 & 6 & 0.0303728 & 135.5 & 135.5 & yes & -15.7331 & $<0.0001$ \\
\hline
\end{tabular}

Table 12 provides statistical information supporting the outcome of the percent accuracy for redwood as having very high statistical significance with p values $<0.0001$.

\section{California Nutmeg}

Table 13. California Nutmeg Results Following 2 Years of Re-evaluation of the Mortality Assessment Model

\begin{tabular}{|c|c|c|c|c|c|c|c|c|c|}
\hline & Tree & $\begin{array}{c}\text { Percent } \\
\text { Canopy } \\
\text { Remaining } \\
\text { PCR }\end{array}$ & $\begin{array}{c}\text { Percent } \\
\text { Canopy } \\
\text { Sprouting } \\
\text { PCS }\end{array}$ & $\begin{array}{c}\text { Percent of } \\
\text { Root } \\
\text { System } \\
\text { Missing } \\
\text { PRSM }\end{array}$ & $\begin{array}{c}\text { Cambium } \\
\text { Quadrants } \\
\text { Destroyed } \\
\text { by Fire } \\
\text { CQDF }\end{array}$ & $\begin{array}{c}\text { Percent } \\
\text { Accuracy }\end{array}$ & $\begin{array}{c}\text { Sample } \\
\text { Size }\end{array}$ & $\begin{array}{c}\text { Predicted } \\
\text { to Die that } \\
\text { are Still } \\
\text { Living }\end{array}$ & $\begin{array}{c}\text { \# of Trees } \\
\text { Predicted } \\
\text { to Live that } \\
\text { are Dead }\end{array}$ \\
\hline $1.0-8.9$ & California nutmeg & $0 \%$ & $10 \%$ & $33 \%$ & 1 & $58.3 \%$ & 12 & & 5 \\
\hline $9.0-16.9$ & California nutmeg & $0 \%$ & $5 \%$ & $50 \%$ & 2 & $80.0 \%$ & 5 & & 1 \\
\hline$>17.0$ & California nutmeg & $0 \%$ & $0 \%$ & $50 \%$ & 2 & $66.0 \%$ & 3 & & 1 \\
\hline
\end{tabular}


A total of 20 California nutmeg trees were evaluated utilizing the MA. Weighted average for percent accuracy across all diameter classes for California nutmeg was approximately 65\%. A total of 7 errors occurred out of 20 MA predictions.

Statistical evaluation for California nutmeg is not provided because the sample size was too small and failed the test for normal approximation.

\section{Live Oak}

Table 14. Live Oak Results Following 2 Years of Re-evaluation of the Mortality Assessment Model

\begin{tabular}{|c|c|c|c|c|c|c|c|c|c|}
\hline DBH (in) & $\begin{array}{c}\text { Tree } \\
\text { Species } \\
\end{array}$ & $\begin{array}{c}\text { Percent } \\
\text { Canopy } \\
\text { Remaining } \\
\text { PCR } \\
\end{array}$ & $\begin{array}{c}\text { Percent } \\
\text { Canopy } \\
\text { Sprouting } \\
\text { PCS } \\
\end{array}$ & $\begin{array}{c}\text { Percent of } \\
\text { Root } \\
\text { System } \\
\text { Missing } \\
\text { PRSM } \\
\end{array}$ & $\begin{array}{c}\text { Cambium } \\
\text { Quadrants } \\
\text { Destroyed } \\
\text { by Fire } \\
\text { CQDF } \\
\end{array}$ & $\begin{array}{c}\text { Percent } \\
\text { Accuracy }\end{array}$ & $\begin{array}{c}\text { Sample } \\
\text { Size } \\
\end{array}$ & \begin{tabular}{|c|} 
\# of Trees \\
Predicted \\
to Die that \\
are Still \\
Living \\
\end{tabular} & $\begin{array}{l}\text { \# of Trees } \\
\text { Predicted } \\
\text { to Live that } \\
\text { are Dead }\end{array}$ \\
\hline $1.0-8.9$ & Live oak & $0 \%$ & $10 \%$ & $33 \%$ & 1 & $85.9 \%$ & 207 & 11 & 18 \\
\hline $9.0-16.9$ & Live oak & $0 \%$ & $5 \%$ & $66 \%$ & 2 & $88.0 \%$ & 150 & 4 & 14 \\
\hline$>17.0$ & Live oak & $0 \%$ & $0 \%$ & $66 \%$ & 3 & $89.1 \%$ & 74 & 1 & 7 \\
\hline
\end{tabular}

A total of 431 live oak trees were evaluated utilizing the MA. Weighted average for percent accuracy across all diameter classes for live oak was approximately $87 \%$. A total of 55 errors occurred out of 431 MA predictions. 
Table 15. Live Oak Statistics

\begin{tabular}{|c|c|c|c|c|c|c|c|c|c|}
\hline \multirow[b]{2}{*}{ DBH" } & \multirow{2}{*}{$\begin{array}{c}\text { Tree } \\
\text { Species }\end{array}$} & \multirow{2}{*}{$\begin{array}{c}\text { Eval. } \\
\text { Correct }\end{array}$} & \multirow{2}{*}{$\begin{array}{c}\text { Eval. } \\
\text { Incorrect }\end{array}$} & \multirow{2}{*}{$\begin{array}{l}\text { Standard } \\
\text { Deviation }\end{array}$} & \multicolumn{4}{|c|}{ Normal Approximation o.k.? } & \multirow{2}{*}{$\begin{array}{c}\text { Two-tailed } \\
\text { P value }\end{array}$} \\
\hline & & & & & $\mathbf{n}^{*} \mathbf{p}$ & $n(1-p) \geq 5$ & $n^{*} p \geq 5 ?$ & $\bar{z}$ & \\
\hline $1.0-8.9$ & Live oak & 189 & 29 & 0.0347524 & 103.5 & 103.5 & yes & -10.3562 & $<0.0001$ \\
\hline $9.0-16.9$ & Live oak & 136 & 18 & 0.0408248 & 75 & 75 & yes & -9.30806 & $<0.0001$ \\
\hline$>17.0$ & Live oak & 67 & 8 & 0.0581238 & 37 & 37 & yes & -6.74236 & $<0.0001$ \\
\hline
\end{tabular}

Table 15 provides statistical information supporting the outcome of the Percent Accuracy for live oak as having very high statistical significance with $\mathrm{p}$ values $<0.0001$.

\section{Tanoak}

Table 16. Tanoak Results Following 2 Years of Re-evaluation of the Mortality Assessment Model

\begin{tabular}{|c|c|c|c|c|c|c|c|c|c|}
\hline DBH (in) & $\begin{array}{c}\text { Tree } \\
\text { Species }\end{array}$ & $\begin{array}{c}\text { Percent } \\
\text { Canopy } \\
\text { Remaining } \\
\text { PCR }\end{array}$ & $\begin{array}{c}\text { Percent } \\
\text { Canopy } \\
\text { Sprouting } \\
\text { PCS }\end{array}$ & $\begin{array}{c}\text { Percent of } \\
\text { Root } \\
\text { System } \\
\text { Missing } \\
\text { PRSM }\end{array}$ & $\begin{array}{c}\text { Cambium } \\
\text { Quadrants } \\
\text { Destroyed } \\
\text { by Fire } \\
\text { CQDF }\end{array}$ & $\begin{array}{l}\text { Percent } \\
\text { Accuracy }\end{array}$ & $\begin{array}{c}\text { Sample } \\
\text { Size }\end{array}$ & \begin{tabular}{|c|} 
\# of Trees \\
Predicted \\
to Die that \\
are Still \\
Living
\end{tabular} & $\begin{array}{l}\text { \# of Trees } \\
\text { Predicted } \\
\text { to Live that } \\
\text { are Dead }\end{array}$ \\
\hline $1.0-8.9$ & Tanoak & $0 \%$ & $10 \%$ & $33 \%$ & 1 & $88.0 \%$ & 302 & 7 & 20 \\
\hline $9.0-16.9$ & Tanoak & $0 \%$ & $5 \%$ & $66 \%$ & 2 & $83.9 \%$ & 181 & 9 & 20 \\
\hline$>17.0$ & Tanoak & $0 \%$ & $0 \%$ & $66 \%$ & 3 & $95.4 \%$ & 66 & & 3 \\
\hline
\end{tabular}

A total of 549 tanoak trees were evaluated utilizing the MA. Weighted average for percent accuracy across all diameter classes for tanoak was approximately $88 \%$. A total of 59 errors occurred out of 549 MA predictions. 
Table 17. Tanoak Statistics

\begin{tabular}{|c|c|c|c|c|c|c|c|c|c|}
\hline \multirow[b]{2}{*}{ DBH" } & \multirow{2}{*}{$\begin{array}{c}\text { Tree } \\
\text { Species }\end{array}$} & \multirow{2}{*}{$\begin{array}{c}\text { Eval. } \\
\text { Correct }\end{array}$} & \multirow{2}{*}{$\begin{array}{c}\text { Eval. } \\
\text { Incorrect }\end{array}$} & \multirow{2}{*}{$\begin{array}{l}\text { Standard } \\
\text { Deviation }\end{array}$} & \multicolumn{4}{|c|}{ Normal Approximation o.k.? } & \multirow{2}{*}{$\begin{array}{c}\text { Two-tailed } \\
\text { P value }\end{array}$} \\
\hline & & & & & $\mathbf{n}^{*} \mathbf{p}$ & $n(1-p) \geq 5$ & $n^{*} p \geq 5 ?$ & $\mathbf{z}$ & \\
\hline $1.0-8.9$ & Tanoak & 282 & 27 & 0.0287718 & 151 & 151 & yes & -14.2708 & $<0.0001$ \\
\hline $9.0-16.9$ & Tanoak & 161 & 29 & 0.0371647 & 90.5 & 90.5 & yes & -9.14252 & $<0.0001$ \\
\hline$>17.0$ & Tanoak & 63 & 3 & 0.0615457 & 33 & 33 & yes & -7.38549 & $<0.0001$ \\
\hline
\end{tabular}

Table 17 provides statistical information supporting the outcome of the Percent Accuracy for Tanoak as having very high statistical significance with p values $<0.0001$.

\section{Red Alder}

Table 18. Red Alder Results Following 2 Years of Re-evaluation of the Mortality Assessment Model

\begin{tabular}{|c|c|c|c|c|c|c|c|c|c|}
\hline DBH (in) & $\begin{array}{c}\text { Tree } \\
\text { Species } \\
\end{array}$ & \begin{tabular}{|c} 
Percent \\
Canopy \\
Remaining \\
PCR \\
\end{tabular} & $\begin{array}{c}\text { Percent } \\
\text { Canopy } \\
\text { Sprouting } \\
\text { PCS } \\
\end{array}$ & $\begin{array}{l}\text { Percent of } \\
\text { Root } \\
\text { System } \\
\text { Missing } \\
\text { PRSM } \\
\end{array}$ & $\begin{array}{c}\text { Cambium } \\
\text { Quadrants } \\
\text { Destroyed } \\
\text { by Fire } \\
\text { CQDF } \\
\end{array}$ & $\begin{array}{c}\text { Percent } \\
\text { Accuracy } \\
\end{array}$ & $\begin{array}{c}\text { Sample } \\
\text { Size } \\
\end{array}$ & \begin{tabular}{|c|} 
\# of Trees \\
Predicted \\
to Die that \\
are Still \\
Living \\
\end{tabular} & $\begin{array}{l}\text { \# of Trees } \\
\text { Predicted } \\
\text { to Live that } \\
\text { are Dead }\end{array}$ \\
\hline $1.0-8.9$ & Red alder & $0 \%$ & $10 \%$ & $33 \%$ & 1 & $62.5 \%$ & 8 & & 3 \\
\hline $9.0-16.9$ & Red alder & $0 \%$ & $5 \%$ & $50 \%$ & 2 & $0.0 \%$ & 0 & & \\
\hline$>17.0$ & Red alder & $0 \%$ & $0 \%$ & $50 \%$ & 2 & $28.6 \%$ & 7 & & 5 \\
\hline
\end{tabular}

A total of 15 red alder trees were evaluated utilizing the MA. Weighted average for percent accuracy across all diameter classes for red alder was approximately $46 \%$. A total of eight errors occurred out of 15 MA predictions. 
Statistical evaluation for red alder was not provided because the sample size was too small and failed the test for normal approximation.

\section{California Bay}

Table 19. California Bay Results Following 2 Years of Re-evaluation of the Mortality Assessment Model

\begin{tabular}{|c|c|c|c|c|c|c|c|c|c|}
\hline & Tree & $\begin{array}{c}\text { Percent } \\
\text { Canopy } \\
\text { Remaining } \\
\text { PCR }\end{array}$ & $\begin{array}{c}\text { Percent } \\
\text { Canopy } \\
\text { Sprouting } \\
\text { PCS }\end{array}$ & $\begin{array}{c}\text { Percent of } \\
\text { Root } \\
\text { System } \\
\text { Missing } \\
\text { PRSM }\end{array}$ & $\begin{array}{c}\text { Cambium } \\
\text { Quadrants } \\
\text { Destroyed } \\
\text { by Fire } \\
\text { CQDF }\end{array}$ & $\begin{array}{c}\text { Percent } \\
\text { Accuracy }\end{array}$ & $\begin{array}{c}\text { Sample } \\
\text { Size }\end{array}$ & $\begin{array}{c}\text { Predicted } \\
\text { to Die that } \\
\text { are Still } \\
\text { Living }\end{array}$ & $\begin{array}{c}\text { \# of Trees } \\
\text { Predicted } \\
\text { to Live that } \\
\text { are Dead }\end{array}$ \\
\hline $1.0-8.9$ & California bay & $0 \%$ & $10 \%$ & $33 \%$ & 1 & $84.0 \%$ & 119 & 1 & 18 \\
\hline $9.0-16.9$ & California bay & $0 \%$ & $5 \%$ & $50 \%$ & 2 & $66.0 \%$ & 50 & 2 & 15 \\
\hline$>17.0$ & California bay & $0 \%$ & $0 \%$ & $50 \%$ & 2 & $55.0 \%$ & 9 & 3 & 1 \\
\hline
\end{tabular}

A total of 178 California bay trees were evaluated utilizing the MA. Weighted average for percent accuracy across all diameter classes for California bay was approximately $77 \%$. A total of 40 errors occurred out of 178 MA predictions.

Table 20. California Bay Statistics

\begin{tabular}{|c|c|c|c|c|c|c|c|c|c|}
\hline & Tree & Eval. & Eval. & Standard & \multicolumn{3}{|c|}{ Normal Approximation o.k.? } & Two-tailed \\
DBH" & Species & Correct & Incorrect & Deviation & n*p & $\mathbf{n}(\mathbf{1}-\mathbf{p}) \geq \mathbf{5}$ & $\mathbf{n}^{*} \mathbf{p} \geq \mathbf{5}$ ? & $\mathbf{z}$ & P value \\
\hline $1.0-8.9$ & California bay & 101 & 19 & 0.0458349 & 59.5 & 59.5 & yes & -7.42526 & $<0.0001$ \\
\hline $9.0-16.9$ & California bay & 35 & 17 & 0.0707107 & 25 & 25 & yes & -2.26274 & $<0.0237$ \\
\hline
\end{tabular}


Table 20 provides statistical information supporting the outcome of the Percent Accuracy for California bay as having very high statistical significance with p values $<0.0001$ for $1.0-8.9$ ” DBH. Also shown in Table 20 is that the 9.0-16.9” DBH class was statistically significant with a p value of $<0.0237$. The $>17.0$ " DBH class did not have a large enough sample size to pass the test for normal approximation.

\section{Pacific Madrone}

Table 21. Pacific Madrone Results Following 2 Years of Re-evaluation of the Mortality Assessment Model

\begin{tabular}{|c|c|c|c|c|c|c|c|c|c|}
\hline DBH (in) & $\begin{array}{c}\text { Tree } \\
\text { Species }\end{array}$ & $\begin{array}{c}\text { Percent } \\
\text { Canopy } \\
\text { Remaining } \\
\text { PCR } \\
\end{array}$ & $\begin{array}{c}\text { Percent } \\
\text { Canopy } \\
\text { Sprouting } \\
\text { PCS } \\
\end{array}$ & $\begin{array}{c}\text { Percent of } \\
\text { Root } \\
\text { System } \\
\text { Missing } \\
\text { PRSM } \\
\end{array}$ & $\begin{array}{c}\text { Cambium } \\
\text { Quadrants } \\
\text { Destroyed } \\
\text { by Fire } \\
\text { CQDF } \\
\end{array}$ & $\begin{array}{c}\text { Percent } \\
\text { Accuracy } \\
\end{array}$ & $\begin{array}{c}\text { Sample } \\
\text { Size } \\
\end{array}$ & \begin{tabular}{|c|} 
\# of Trees \\
Predicted \\
to Die that \\
are Still \\
Living \\
\end{tabular} & $\begin{array}{c}\text { \# of Trees } \\
\text { Predicted } \\
\text { to Live that } \\
\text { are Dead }\end{array}$ \\
\hline $1.0-8.9$ & Pacific madrone & $0 \%$ & $10 \%$ & $33 \%$ & 1 & $77.0 \%$ & 61 & & 12 \\
\hline $9.0-16.9$ & Pacific madrone & $0 \%$ & $5 \%$ & $50 \%$ & 2 & $73.0 \%$ & 15 & & 4 \\
\hline$>17.0$ & Pacific madrone & $0 \%$ & $0 \%$ & $50 \%$ & 2 & $50.0 \%$ & 6 & 2 & 3 \\
\hline
\end{tabular}

A total of 82 Pacific Madrone trees were evaluated utilizing the MA. Weighted average for percent accuracy across all diameter classes for Pacific madrone was approximately 74\%. A total of 21 errors occurred out of 82 MA predictions.

Table 22. Pacific Madrone Statistics

\begin{tabular}{|c|c|c|c|c|c|c|c|c|c|}
\hline & Tree & Eval. & Eval. & Standard & \multicolumn{3}{|c|}{ Normal Approximation o.k.? } & Two-tailed \\
\cline { 6 - 8 } DBH" & Species & Correct & Incorrect & Deviation & $\mathbf{n} \mathbf{n}$ & $\mathbf{n}(\mathbf{1}-\mathbf{p}) \geq \mathbf{5}$ & $\mathbf{n}$ * $\mathbf{p} \geq \mathbf{5}$ ? & $\mathbf{z}$ & P value \\
\hline $1.0-8.9$ & Pacific madrone & 49 & 12 & 0.0640184 & 30.5 & 30.5 & yes & -4.73736 & $<0.0001$ \\
\hline
\end{tabular}


Table 22 provides statistical information supporting the outcome of the Percent Accuracy for Pacific Madrone as having very high statistical significance with p values $<0.0001$ for $1.0-8.9$ DBH. DBH classes $9.0-16.9$ ” and $>17.0$ " did not have a large enough sample size to pass the test for normal approximation.

\section{Big Leaf Maple}

Table 23. Big Leaf Maple Results Following 2 Years of Re-evaluation of the Mortality Assessment Model

\begin{tabular}{|c|c|c|c|c|c|c|c|c|c|}
\hline DBH (in) & $\begin{array}{c}\text { Tree } \\
\text { Species }\end{array}$ & $\begin{array}{c}\text { Percent } \\
\text { Canopy } \\
\text { Remaining } \\
\text { PCR } \\
\end{array}$ & $\begin{array}{c}\text { Percent } \\
\text { Canopy } \\
\text { Sprouting } \\
\text { PCS }\end{array}$ & $\begin{array}{l}\text { Percent of } \\
\text { Root } \\
\text { System } \\
\text { Missing } \\
\text { PRSM } \\
\end{array}$ & $\begin{array}{c}\text { Cambium } \\
\text { Quadrants } \\
\text { Destroyed } \\
\text { by Fire } \\
\text { CQDF }\end{array}$ & $\begin{array}{c}\text { Percent } \\
\text { Accuracy }\end{array}$ & $\begin{array}{c}\text { Sample } \\
\text { Size } \\
\end{array}$ & \begin{tabular}{|c|} 
\# of Trees \\
Predicted \\
to Die that \\
are Still \\
Living \\
\end{tabular} & $\begin{array}{l}\text { \# of Trees } \\
\text { Predicted } \\
\text { to Live that } \\
\text { are Dead }\end{array}$ \\
\hline $1.0-8.9$ & Big leaf maple & $0 \%$ & $10 \%$ & $33 \%$ & 1 & $0.0 \%$ & 2 & 1 & 1 \\
\hline $9.0-16.9$ & Big leaf maple & $0 \%$ & $5 \%$ & $50 \%$ & 2 & $0.0 \%$ & 0 & & \\
\hline$>17.0$ & Big leaf maple & $0 \%$ & $0 \%$ & $50 \%$ & 2 & $0.0 \%$ & 0 & & \\
\hline
\end{tabular}

A total of two big leaf maple trees were evaluated utilizing the MA. Weighted average for percent accuracy across all diameter classes for big leaf maple was approximately $0 \%$. A total of two errors occurred out of two MA predictions.

Statistical evaluation for big leaf maple was not provided because the sample size was too small and failed the test for normal approximation. 


\section{Douglas-fir}

Table 24. Douglas-fir Results Following 2 Years of Re-evaluation of the Mortality Assessment Model

\begin{tabular}{|c|c|c|c|c|c|c|c|c|c|}
\hline DBH (in) & $\begin{array}{c}\text { Tree } \\
\text { Species }\end{array}$ & $\begin{array}{c}\text { Percent } \\
\text { Canopy } \\
\text { Remaining } \\
\text { PCR } \\
\end{array}$ & $\begin{array}{c}\text { Percent } \\
\text { Canopy } \\
\text { Sprouting } \\
\text { PCS }\end{array}$ & $\begin{array}{l}\text { Percent of } \\
\text { Root } \\
\text { System } \\
\text { Missing } \\
\text { PRSM } \\
\end{array}$ & $\begin{array}{c}\text { Cambium } \\
\text { Quadrants } \\
\text { Destroyed } \\
\text { by Fire } \\
\text { CQDF } \\
\end{array}$ & $\begin{array}{l}\text { Percent } \\
\text { Accuracy }\end{array}$ & $\begin{array}{c}\text { Sample } \\
\text { Size } \\
\end{array}$ & $\begin{array}{c}\text { \# of Trees } \\
\text { Predicted } \\
\text { to Die that } \\
\text { are Still } \\
\text { Living } \\
\end{array}$ & $\begin{array}{c}\text { \# of Trees } \\
\text { Predicted } \\
\text { to Live that } \\
\text { are Dead }\end{array}$ \\
\hline $1.0-8.9$ & Douglas-fir & $70 \%$ & & $33 \%$ & 1 & & 290 & 8 & 3 \\
\hline $9.0-16.9$ & Douglas-fir & $60 \%$ & N/A & $33 \%$ & 1 & $97.5 \%$ & 122 & 2 & 1 \\
\hline$>17.0$ & Douglas-fir & $60 \%$ & N/A & $33 \%$ & 2 & $90.5 \%$ & 180 & 12 & 5 \\
\hline
\end{tabular}

A total of 592 Douglas-fir trees were evaluated utilizing the MA. Weighted average for percent accuracy across all diameter classes for Douglas-fir was approximately 95\%. A total of 31 errors occurred out of 592 MA predictions.

Table 25. Douglas-fir Statistics

\begin{tabular}{|c|c|c|c|c|c|c|c|c|c|}
\hline & Tree & Eval. & Eval. & Standard & \multicolumn{3}{|c|}{ Normal Approximation o.k.? } & Two-tailed \\
DBH" & Species & Correct & Incorrect & Deviation & $\mathbf{n} \mathbf{n}$ & $\mathbf{n}(\mathbf{1}-\mathbf{p}) \geq \mathbf{5}$ & $\mathbf{n}^{*} \mathbf{p} \geq \mathbf{5}$ ? & $\mathbf{z}$ & P value \\
\hline $1.0-8.9$ & Douglas-fir & 287 & 11 & 0.029361 & 145 & 145 & yes & -15.7375 & $<0.0001$ \\
\hline $9.0-16.9$ & Douglas-fir & 121 & 3 & 0.0452679 & 61 & 61 & yes & -10.5021 & $<0.0001$ \\
\hline$>17.0$ & Douglas-fir & 175 & 17 & 0.0372678 & 90 & 90 & yes & -10.8822 & $<0.0001$ \\
\hline
\end{tabular}


Table 25 provides statistical information supporting the outcome of the Percent Accuracy for Douglas-fir as having very high statistical significance with p values $<0.0001$.

\section{Monterey Pine}

Table 26. Monterey Pine Results Following 2 Years of Re-evaluation of the Mortality Assessment Model

\begin{tabular}{|c|c|c|c|c|c|c|c|c|c|}
\hline DBH (in) & $\begin{array}{c}\text { Tree } \\
\text { Species }\end{array}$ & $\begin{array}{c}\text { Percent } \\
\text { Canopy } \\
\text { Remaining } \\
\text { PCR } \\
\end{array}$ & $\begin{array}{c}\text { Percent } \\
\text { Canopy } \\
\text { Sprouting } \\
\text { PCS }\end{array}$ & $\begin{array}{c}\text { Percent of } \\
\text { Root } \\
\text { System } \\
\text { Missing } \\
\text { PRSM }\end{array}$ & $\begin{array}{c}\text { Cambium } \\
\text { Quadrants } \\
\text { Destroyed } \\
\text { by Fire } \\
\text { CQDF }\end{array}$ & $\begin{array}{l}\text { Percent } \\
\text { Accuracy }\end{array}$ & $\begin{array}{c}\text { Sample } \\
\text { Size }\end{array}$ & \begin{tabular}{|c|} 
\# of Trees \\
Predicted \\
to Die that \\
are Still \\
Living \\
\end{tabular} & $\begin{array}{l}\text { \# of Trees } \\
\text { Predicted } \\
\text { to Live that } \\
\text { are Dead }\end{array}$ \\
\hline $1.0-8.9$ & Monterey pine & $70 \%$ & N/A & $33 \%$ & 1 & $82.3 \%$ & 17 & 3 & \\
\hline $9.0-16.9$ & Monterey pine & $60 \%$ & N/A & $33 \%$ & 1 & $78.9 \%$ & 19 & 4 & \\
\hline$>17.0$ & Monterey pine & $60 \%$ & N/A & $33 \%$ & 2 & $100.0 \%$ & 2 & & \\
\hline
\end{tabular}

A total of 38 Monterey pine trees were evaluated utilizing the MA. Weighted average for percent accuracy across all diameter classes for Monterey pine was approximately $81 \%$. A total of seven errors occurred out of 38 MA predictions.

Table 27. Monterey Pine Statistics

\begin{tabular}{|c|c|c|c|c|c|c|c|c|c|}
\hline \multirow[b]{2}{*}{ DBH" } & \multirow{2}{*}{$\begin{array}{c}\text { Tree } \\
\text { Species }\end{array}$} & \multirow{2}{*}{$\begin{array}{c}\text { Eval. } \\
\text { Correct }\end{array}$} & \multirow{2}{*}{\begin{tabular}{c|} 
Eval. \\
Incorrect
\end{tabular}} & \multirow{2}{*}{$\begin{array}{l}\text { Standard } \\
\text { Deviation }\end{array}$} & \multicolumn{4}{|c|}{ Normal Approximation o.k.? } & \multirow{2}{*}{$\begin{array}{c}\text { Two-tailed } \\
\text { P value }\end{array}$} \\
\hline & & & & & $\mathbf{n}^{*} \mathbf{p}$ & $n(1-p) \geq 5$ & $n^{*} p \geq 5 ?$ & $\mathbf{z}$ & \\
\hline $1.0-8.9$ & Monterey pine & 17 & 3 & & 8.5 & & yes & -2.66789 & $<0.0076$ \\
\hline $9.0-16.9$ & Monterey pine & 19 & 4 & 0.1147079 & 9.5 & 9.5 & yes & -2.52357 & $<0.0116$ \\
\hline
\end{tabular}


Table 27 provides statistical information supporting the outcome of the Percent Accuracy for Monterey pine as very statistically significant with $\mathrm{p}$ values $<0.0076$ for 1.0-8.9 DBH. Also shown in Table 18 is that the $9.0-16.9$ ” DBH class was statistically significant with p values $<0.0116$. The $>17.0$ " DBH class did not have a large enough sample size to pass the test for normal approximation.

\section{Knobcone Pine}

Table 28. Knobcone Pine Results Following 2 Years of Re-evaluation of the Mortality Assessment Model

\begin{tabular}{|c|c|c|c|c|c|c|c|c|c|}
\hline DBH (in) & $\begin{array}{c}\text { Tree } \\
\text { Species }\end{array}$ & \begin{tabular}{|c} 
Percent \\
Canopy \\
Remaining \\
PCR
\end{tabular} & $\begin{array}{c}\text { Percent } \\
\text { Canopy } \\
\text { Sprouting } \\
\text { PCS }\end{array}$ & $\begin{array}{l}\text { Percent of } \\
\text { Root } \\
\text { System } \\
\text { Missing } \\
\text { PRSM }\end{array}$ & $\begin{array}{c}\text { Cambium } \\
\text { Quadrants } \\
\text { Destroyed } \\
\text { by Fire } \\
\text { CQDF }\end{array}$ & $\begin{array}{l}\text { Percent } \\
\text { Accuracy }\end{array}$ & $\begin{array}{c}\text { Sample } \\
\text { Size }\end{array}$ & $\begin{array}{c}\text { \# of Trees } \\
\text { Predicted } \\
\text { to Die that } \\
\text { are Still } \\
\text { Living }\end{array}$ & $\begin{array}{c}\text { \# of Trees } \\
\text { Predicted } \\
\text { to Live that } \\
\text { are Dead }\end{array}$ \\
\hline $1.0-8.9$ & Knobcone pine & $70 \%$ & $\mathrm{~N} / \mathrm{A}$ & $33 \%$ & 1 & $0.0 \%$ & 0 & & \\
\hline $9.0-16.9$ & Knobcone pine & $60 \%$ & $\mathrm{~N} / \mathrm{A}$ & $33 \%$ & ( & $100.0 \%$ & 3 & & \\
\hline$>17.0$ & Knobcone pine & $60 \%$ & N/A & $33 \%$ & 2 & $100.0 \%$ & 3 & & \\
\hline
\end{tabular}

Knobcone pine had an extremely small sample size of 6 trees making it difficult to draw any significant conclusions. It should be noted that the burn severity on these six trees was extremely high. Percent accuracy across all diameter classes for knobcone pine was approximately $100 \%$. A total of zero errors occurred out of six MA predictions.

Statistical evaluation for knobcone pine was not provided because the sample size was too small and failed the test for normal approximation. 


\section{CHAPTER 5}

Conclusions and Recommendations

\section{$\underline{\text { Conclusions }}$}

In the aftermath of the Lockheed Fire of 2009, Swanton Pacific Ranch needed to make critical decisions for forest recovery on lands within the burn area. Landowners and foresters needed a reliable method to predict tree mortality resulting from wildfire for the redwood region. To date, there was only one publication, Finney (1993), that provided a type of logistic regression model to evaluate tree mortality in the redwood region following a prescribed burn (Woolley, 2012). Certain model variables were derived from Finney (1993) and incorporated into the MA model. The Mortality Assessment (MA) model was a significant step in the right direction with the overall accuracy across all species and diameters at $89.3 \%(n=2877$ trees $)$. The MA model has provided promising results but needs to be replicated in other areas of the redwood region beyond the Santa Cruz Mountains.

It should be recognized again that the design of the MA model should result in a slight overestimation of mortality. The purpose of this is to ensure that the information utilized for a Sustainability Analysis (SA) does not overestimate the amount of timber surviving the fire. The optimum result is a conservative estimate for forest volume and forest projection. The inverse of this is that the MA should not be used to evaluate mortality for the purpose of salvage harvesting dead trees. Under that scenario, the MA 
model could deem a tree dead, when in fact it may live. The cutting prescription for a salvage harvest, which normally identifies the removal of all dead trees, could allow potentially live trees to be removed based on the MA model predictions.

Preliminary results for the 2012 MA model re-evaluation suggest that the MA model is still slightly overestimating mortality in sprouting species. Overall accuracy dropped from $89.3 \%$ to $87.9 \%$, a total drop of $1.4 \%$, for this third year re-evaluation period. The majority of accuracy issues continue to exist in the lower and middle DBH classes (trees that represent low volume per tree amounts). It is expected that the resulting calculation and extrapolation errors will remain insignificant for overall volume predictions in the SA due to the errors occurring in the smaller diameter, thus low volume, trees.

Of interest, in the third year re-evaluation period in 2012, Douglas-fir transitioned to slightly overestimating mortality over all DBH size classes which is, of course, the intended outcome of the MA model. It is suspected that the increased PCR threshold initially applied in the MA model, $10 \%$ greater than literature suggested, was excessive. If this is true, it adds additional support to the adjusted MA model, which returned PCR to the approximate thresholds recommended in the literature.

The intent of the Mortality Assessment model is to act as a starting point for research on logistic regression models for tree mortality following wildfire in the redwood region. The MA model is the culmination of many different opinions from foresters with significant experience in wildfire in the redwood region. Similarly, Wagener's work from 1961 was the beginning of logistic regression models for tree mortality following wildfire in the Sierras. Many years after Wagener's work, new 
research models for the Sierras have been implemented, examined and validated. With additional research in the redwood region, the contribution that each variable makes to the prediction of tree mortality could be understood. Considering the financial, social, educational and inspirational values that redwood trees and other sprouting species in the redwood region offer, understanding their mortality resulting from wildfire is extremely important to understand if we intend to maintain these values.

\section{Recommendations for Replication of the MA Model}

The purpose of the MA model, initially, was to serve as a measurement protocol for mortality in support of a new Sustainability Analysis (SA) submitted to Cal Fire on behalf of Cal Poly SPR. It was not until Swanton Pacific Ranch staff realized how little scientific guidance existed on fire-induced tree mortality in the redwood region that consideration was given to the MA model as a thesis or publication. The following is a series of recommendations for future replication of the MA model.

The MA model does not consider volume adjustments for defect which can be expected following a wildfire. It is recommended that an additional calculation be prepared to adjust the final volume in the stock tables to account for defect. This should be calculated upon completion of a SA analysis using the MA model. Alternatively, defect could be calculated through available historic data if available.

Values for the variables in the MA model (PCR, PCS, PRSM, and CQDF) were not successfully recorded. Essentially, each time a tree was evaluated with the MA model in 2009, values for PCR, PCS, PRSM, and CQDF were assessed but not written down when measuring the model variables against the species' mortality thresholds. The study had potential to be very robust in determining which variables influence the MA 
model explanatory power, but the data was lacking. Researchers should ensure that information is recorded in detail for these model variables.

The findings from four years of field observations in 2009 to 2012, suggest that more percent canopy remaining (PCR), percent canopy sprouting (PCS), and a reduction in cambium quadrants destroyed by fire (CQDF) for some small and medium diameter classes were likely needed to offset dead errors (Type 1 errors) reported in the Results section. The intent of altering the thresholds for PCR, PCS, and CQDF was to slightly overestimate the amount of dead errors to living errors (Type II errors). Adjusted MA models are provided in Tables 29, 30, and 31 to reflect the recommended changes based on 4 years of field observations.

Table 29. Adjusted Mortality Assessment Model for 1.0 - 8.9 inch DBH Classes

\begin{tabular}{|l|c|c|c|c|}
\hline \multicolumn{1}{|c|}{$\begin{array}{c}\text { Tree } \\
\text { Species }\end{array}$} & $\begin{array}{c}\text { Percent Canopy } \\
\text { Remaining } \\
\text { PCR }\end{array}$ & $\begin{array}{c}\text { Percent Canopy } \\
\text { Sprouting } \\
\text { PCS }\end{array}$ & $\begin{array}{c}\text { Percent of Root } \\
\text { System Missing } \\
\text { PRSM }\end{array}$ & $\begin{array}{c}\text { Cambium Quadrants } \\
\text { Destroyed by Fire } \\
\text { CQDF }\end{array}$ \\
\hline \multirow{2}{*}{$\begin{array}{l}\text { Redwood } \\
\text { California nutmeg } \\
\text { Live oak }\end{array}$} & $33 \%$ & $20 \%$ & $33 \%$ & 1 \\
\cline { 2 - 5 } $\begin{array}{l}\text { Tanoak } \\
\text { Red alder }\end{array}$ & $33 \%$ & $33 \%$ & $33 \%$ & 1 \\
\cline { 2 - 5 } \begin{tabular}{l} 
California bay \\
Pacific madrone \\
Big leaf maple \\
Douglas-fir \\
Monterey pine \\
\cline { 2 - 5 } Knobcone pine
\end{tabular} & $20 \%$ & $20 \%$ & $33 \%$ & 1 \\
\cline { 2 - 5 } & $20 \%$ & $20 \%$ & $33 \%$ & 1 \\
\cline { 2 - 5 } & $40 \%$ & $10 \%$ & $33 \%$ & 1 \\
\cline { 2 - 5 } & $33 \%$ & $10 \%$ & $33 \%$ & 1 \\
\hline & $60 \%$ & $10 \%$ & $33 \%$ & 1 \\
\cline { 2 - 5 } & $60 \%$ & $10 \%$ & $33 \%$ & 1 \\
\hline
\end{tabular}


Table 30. Adjusted Mortality Assessment Model for 9.0 - 16.9 inch DBH Classes

\begin{tabular}{|l|c|c|c|c|}
\hline \multicolumn{1}{|c}{$\begin{array}{c}\text { Tree } \\
\text { Species }\end{array}$} & $\begin{array}{c}\text { Percent Canopy } \\
\text { Remaining } \\
\text { PCR }\end{array}$ & $\begin{array}{c}\text { Percent Canopy } \\
\text { Sprouting } \\
\text { PCS }\end{array}$ & $\begin{array}{c}\text { Percent of Root } \\
\text { System Missing } \\
\text { PRSM }\end{array}$ & $\begin{array}{c}\text { Cambium Quadrants } \\
\text { Destroyed by Fire } \\
\text { CQDF }\end{array}$ \\
\hline \multirow{2}{*}{$\begin{array}{l}\text { Redwood } \\
\text { California nutmeg } \\
\text { Live oak } \\
\text { Tanoak } \\
\text { Red alder } \\
\text { California bay } \\
\text { Pacific madrone } \\
\text { Big leaf maple } \\
\text { Douglas-fir } \\
\text { Monterey pine } \\
\text { Knobcone pine }\end{array}$} & $0 \%$ & $5 \%$ & $66 \%$ & 2 \\
\cline { 2 - 5 } & $25 \%$ & $25 \%$ & $50 \%$ & 1 \\
\cline { 2 - 5 } & $20 \%$ & $20 \%$ & $66 \%$ & 2 \\
\cline { 2 - 5 } & $20 \%$ & $20 \%$ & $66 \%$ & 1 \\
\cline { 2 - 5 } & $40 \%$ & $5 \%$ & $50 \%$ & 1 \\
\cline { 2 - 5 } & $33 \%$ & $10 \%$ & $50 \%$ & 1 \\
\cline { 2 - 5 } & $50 \%$ & $10 \%$ & $50 \%$ & 1 \\
\hline
\end{tabular}

Table 31. Adjusted Mortality Assessment Model for $>17.0$ inch DBH Classes

\begin{tabular}{|c|c|c|c|c|}
\hline $\begin{array}{c}\text { Tree } \\
\text { Species }\end{array}$ & \begin{tabular}{|c|} 
Percent Canopy \\
Remaining \\
PCR
\end{tabular} & $\begin{array}{l}\text { Percent Canopy } \\
\text { Sprouting } \\
\text { PCS } \\
\end{array}$ & \begin{tabular}{|c|} 
Percent of Root \\
System Missing \\
PRSM
\end{tabular} & $\begin{array}{c}\text { Cambium Quadrants } \\
\text { Destroyed by Fire } \\
\text { CQDF }\end{array}$ \\
\hline \multirow{11}{*}{$\begin{array}{l}\text { Redwood } \\
\text { California nutmeg } \\
\text { Live oak } \\
\text { Tanoak } \\
\text { Red alder } \\
\text { California bay } \\
\text { Pacific madrone } \\
\text { Big leaf maple } \\
\text { Douglas-fir } \\
\text { Monterey pine } \\
\text { Knobcone pine }\end{array}$} & $0 \%$ & $0 \%$ & $66 \%$ & 3 \\
\hline & $25 \%$ & $25 \%$ & $50 \%$ & 2 \\
\hline & $10 \%$ & $10 \%$ & $66 \%$ & 3 \\
\hline & $0 \%$ & $0 \%$ & $66 \%$ & 3 \\
\hline & $33 \%$ & $0 \%$ & $50 \%$ & 2 \\
\hline & $33 \%$ & $0 \%$ & $50 \%$ & 2 \\
\hline & $25 \%$ & $10 \%$ & $50 \%$ & 2 \\
\hline & $33 \%$ & $0 \%$ & $50 \%$ & 2 \\
\hline & $50 \%$ & N/A & $33 \%$ & 2 \\
\hline & $50 \%$ & N/A & $33 \%$ & 2 \\
\hline & $50 \%$ & N/A & $33 \%$ & 2 \\
\hline
\end{tabular}

More detailed information on the relationship between sprouting axillary buds, roots, and carbohydrate storage in sprouting species could also advance the MA model. A future research objective could be to dissect a sample of redwood trees, or other 
sprouting tree species, that burned with varying levels of severity to answer some of the following questions:

- What is the condition of the cambium near the point of axillary buds that sprout months and even years after the fire?

- How much root re-growth has occurred on sprouting species, and more specifically redwood groves, since the fire?

- How much carbohydrate storage is accumulated in limbs, stem, bole, roots, and stumps by species based on tree size?

- After calculating the amount of carbohydrate storage, how much "survival time" does this provide the coppice sprouting tree to recover from the severity of fire?

- What relationship to survival could axillary buds, roots, and carbohydrates for sprouting tree species offer to adjust the MA model?

- How did salvage harvesting affect the survival of sprouting species that shared root systems with other trees that were salvage harvested?

Finally, the MA model can be applied to other timber inventory methods that do not employ a Continuous Forest Inventory (CFI) system. Like other timber cruises, one can establish a basal area factor for a variable plot sample and implement the measurement methodology for the six different variables on “in trees": species, DBH, PCR, PCS, PRSM, and CQDF. A nested regeneration plot can be established to evaluate the status of regeneration. The information can then be processed to create stand and stock tables following normal timber cruising protocols. In large scale situations where LiDAR and infrared are being used to evaluate tree mortality, the MA model with GPS plot locations can be used to ground truth aerial predictions. 


\section{LITERATURE CITED}

Burns, Russell M., and Honkala, Barbara H. 1990. Silvics of North America Volumes 1 and 2. USDA. Handbook 654.

Auten, Steve R., and Hamey, Nadia. 2011. Damage and mortality assessment of redwood and mixed conifer forest types in Santa Cruz County following wildfire. 2011 Proc. of the Redwood Science Symposium held at Univ. of CA Santa Cruz. USDA. PSW-GTR-238. Part II, 347-355.

Finney, M.A., and Martin, R.E. 1993. Modeling effects of prescribed fire on younggrowth coast redwood trees. Canadian Journal of Forest Research. 23:1125-1135.

Fowler, James F. and Sieg, Carolyn H. 2004. Postfire mortality of ponderosa pine and Douglas-fir. USDA. RMRS-GTR-132.

Fritz, Emanuel. 1932. The role of fire in the redwood region. Journal of Forestry. Pg. 939-950.

Hood, Sharon M., Smith, Sheri L., and Cluck, Daniel R. 2007. Delayed conifer mortality following fire in California. USDA. RMRS-GTR-203.

Hood, Sharon M., Cluck, Daniel R., Smith, Sheri L., and Ryan, Kevin C. 2008. Using bark char codes to predict post-fire cambium mortality. Fire Ecology, Vol. 4, No. 1.

Loomis, Robert M. 1973. Estimating fire-caused mortality and injury in oak-hickory forests. USDA. Research Paper NC-94.

Parts of a Tree (internet), Raleigh, North Carolina. North Carolina Forestry Association; 2012 (cited 2012 Nov. 18 ${ }^{\text {th }}$ ). Available from: http://www.ncforestry.org/ WEBPAGES/CLASSROOM\%20ACTIVITIES/Trees/PartsOfTree/parts.htm\#Crown.

Perkins, D, White, R. 2009. Lockheed Fire Burn Severity Map. Created for and housed at Cal Poly Swanton Pacific Ranch.

Peterson, D.L. 1984. Predicting fire-caused mortality in four northern rocky mountain conifers. In: Proceedings of the 1983 Convention of the Society of American Foresters, New Forests for Changing World; 1983 October 16-20, Portland OR. Society of American Foresters, Bethesda, MD: 276-280. 
Peterson, D.L. 1985. Crown scorch volume and scorch height: estimates of postfire tree condition. Canadian Journal of Forest Research. 15:596-598.

Peterson, D.L. and Arbaugh, M.J. 1986. Postfire survival in Douglas-fir and lodgepole pine: comparing the effects of crown and bole damage. Canadian Journal of Forest Resources. 19:1175-1179.

Peterson, D.L. and Arbaugh, M.J. 1989. Estimating postfire survival of Douglas-fir in the Cascade Range. Canadian Journal of Forest Research. 19:530-533.

Regelbrugge, Jon C., Conrad, Susan G. 1993. Modeling tree mortality following wildfire in pinus ponderosa forests in the central Sierra Nevada of California. Int. J. Wildland Fire. 3(3):139-148.

Ryan, K.C. 1982. Techniques for assessing fire damage to trees. In: J. Lotan, Ed., Fire, its field effects: proceedings of the symposium, a symposium sponsored jointly by the Intermountain Fire Council and the Rocky Mountain Fire Council; 1982 October 19-21; Jackson, Wyoming. Intermountain Fire Council. Pg. 1-11.

Ryan, K.C. and Reinhardt, E.D. 1988. Modeling long-term fire-caused mortality of seven western conifers. Canadian Journal of Forest Research. 18(10):1291-1297.

Smith, Sheri L., Cluck, Daniel R. 2009. Marking guidelines for fire-injured trees in California. USDA. Report \# R0-09-01.

Wagener, W.W. 1961. Guidelines for estimating the survival of fire-damaged trees in California. Miscellaneous paper-60, Pacific Southwest Forest and Ranch Experiment Station, Berkeley, CA. 11 p.

Weatherspoon, Phillip C. 1987. Evaluating fire damage to trees. Proceedings $9^{\text {th }}$ Annual Forest Vegetative Management Conference. Redding, CA. Pg. 106-110.

Woolley, Travis, Shaw, David C., Ganio, Lisa M., Fitzgerald, Stephen. 2012. A review of logistic regression models used to predict post-fire tree mortality of western North American conifers. International Journal of Wildland Fire. 21:1-35. 
Appendix A

\title{
Damage and mortality assessment of redwood and mixed conifer forest types in Santa Cruz County following wildfire
}

\author{
Steve R. Auten ${ }^{1}$ and Nadia Hamey ${ }^{1}$
}

\begin{abstract}
On August 12, 2009, the Lockheed Fire ignited the west slope of the Santa Cruz Mountains burning approximately 7,819 acres. A mixture of vegetation types were in the path of the fire, including approximately 2,420 acres of redwood forest and 1,951 acres of mixed conifer forest types representative of the Santa Cruz Mountains. Foresters and land managers were left with tough decisions on how to treat tree damage and mortality compounded by the Pine Mountain Fire which occurred in the same area in 1948. Big Creek Lumber Company (BCL), Cal Poly’s Swanton Pacific Ranch (SPR) and other professionals familiar with this region of redwood teamed up to develop a method for evaluating damage and mortality. Qualitative criteria for evaluating stand damage focused on historic defect, cambial death, root damage, and associated fire intensity. Quantitative damage criteria was used to contrive three mortality assessment tables, broken up by diameter class (1-8, 9-16, 17+), for all tree species and tested against 83, one-fifth acre fixed plots from SPR's Continuous Forest Inventory. Since the initial mortality evaluation using the new tables in Fall of 2009, each of the 2877 trees have been re-evaluated in Spring 2010 and Spring 2011. Accuracy against the initial evaluation is 89.3 percent.
\end{abstract}

Keywords: damage, hardwood, mortality, redwood

\section{Introduction}

What should be harvested to encourage regeneration of selectively-managed forestland in the Southern Subdistrict of the Coast Forest District following wildfire? What determines tree mortality for the purpose of amending the sustainability analysis of (SA) a Non-industrial Timber Management Plan (NTMP) following wildfire? Charged with managing and maintaining the health and vigor of the forest ecosystem, foresters and land managers need an accurate way of field-evaluating damage and mortality in conifers and hardwoods immediately following wildfire. These questions and many others not related to forest health, loomed for the local forestry community following the Lockheed Fire. This paper is a case study to provide other foresters and land managers with information and knowledge gained through our experiences following the 
Lockheed Fire to help make decisions about damage and mortality in conifers and hardwoods as a result of wildfire, which others may experience sometime in their careers.

\section{Seasonal Context}

The time of year and prevailing wind direction during the Lockheed Fire was very similar to conditions during the Pine Mountain Fire, which is the last recorded and mapped fire perimeter within the Lockheed Fire area. The Pine Mountain Fire burned in September 1948, 61 years ago, and consumed 15,899 acres. The Lockheed Fire also took place in late summer, a season when historically lightning strikes have caused fires in the Santa Cruz Mountains; although the Lockheed Fire was human-caused. Other large historic fires are known to have occurred in the vicinity of the Lockheed Fire near the turn of the 19th century associated with logging and power generation projects in the Scotts Creek watershed.

\section{Damage Assessment}

The land management goals of the large Timber Production zoned parcels are for timber production and protection of associated resources such as wildlife, fisheries, and watershed. The mission of the landowners affected by this fire was to determine the level of defect and remove some of the most damaged wood to bring defect down to an acceptable level for future management.

Consider the accounting for a timber harvest conducted a few years ago in an area heavily hit by the Pine Mountain Fire, where the defect was 23\%, about 11\% higher than "average" for the Santa Cruz Mountains. The loss of net return to the landowner was about \$71,500 for approximately 1 million board feet harvested.

\section{Fire intensity}

In order to understand burn intensity patterns, fire behavior was estimated for the day the fire started under the prevailing weather and fuel conditions. Five different fuel models, representing five vegetation types, were used in the BehavePlus computer simulation to estimate fire behavior. The BehavePlus fire modeling system is a collection of models that describe fire behavior, fire effects and the fire environment.

Burn severity analysis was conducted initially by a Risk Assessment Team put together by Cal-Fire. The team used a Burned Area Reflectance Classification (BARC) satellite-derived map of post-vegetation condition made by comparing satellite near and mid infrared reflectance values. This data was evaluated in several ways. Some team members flew over the fire area on the first clear day and photographed post-fire conditions. Other team members made groundbased observations over the fire area while assisting with suppression and suppression repair efforts. Burn severity across the entire burn area was estimated to be $14 \%$ very high, $37 \%$ high, $43 \%$ moderate, and $6 \%$ low.

\section{Research}

Foresters working in the burned area began researching what to expect from the various levels of burn damage. Little research or literature is available relative to wildfire impacts on redwood defect and mortality, especially in this region. Several papers about fire damage and anticipated mortality from prescribed burns in mixed-conifer forests were helpful. One paper 
emerged with practical insights on tree mortality and wildfire from Willis W. Wagener in 1961, called "Guidelines for Estimating the Survival of Fire Damaged Trees in California."

Following a literature review, many conversations occurred with other foresters and land managers throughout the state to learn from their experiences. Contacts included:

- Mike Jani and John Anderson from Mendocino Redwood Company, with experience the year prior conducting salvage operations on the Lightning Complex Fire.

- Lathrop Leonard from California State Parks with experience in prescribed burning.

- Rich Casale, District Conservationist, USDA Natural Resources Conservation Service.

- David Van Lennep and Mike Duffy from Redwood Empire Sawmills. We toured the Summit Fire area that has been salvage logged by them the year prior.

- Dale Holderman, Chief Forester emeritus for Big Creek Lumber Company, with significant experience in defect levels in the Santa Cruz Mountains.

Repeatedly other land managers stated that the salvage operations undertaken in burned areas did not remove enough of the damaged timber. Significant loss of future commercial value is expected as a result of the persistent fire-scar defect.

\section{Cambium death, root damage and crown scorch}

Determining the level of internal defect from the external visual indicators on the tree immediately post-fire was very difficult. The methodology evolved over the course of months investigating the extent of the burn and initiating salvage operations in the most severely burned areas, and is still ongoing. Foresters started out chipping into the bark of trees with a hatchet to see what type of bark characteristics are indicative of damage to the cambium layer. Immediately after the fire as the cambium was dying, that layer appeared very dry compared to live cambium which oozed resin. Dying cambium also sometimes appeared grey versus red or pink for live cambium. A particularly useful tool turned out to be delivering a sound kick to the tree. A hollow sound would indicate that the cambium had died and the wood separated from the bark.

On some trees bark burned completely through exposing the wood underneath. Other trees had cracks in the bark showing the wood indicating that the cambium had been burned. Other trees had hollowed-out bases where large quantities of roots had been burned. Reduced root mass affects the tree's growth rate and if the damage is substantial, it can affect the trees stability and slow the rate of recovery. Many scorched trees that experienced crown fire lost all of their needles during the first winter, which provided a good carpet of mulch on the ground.

Trees with cambium damage in multiple quadrants were considered to be substantially damaged, especially when occurring in conjunction with previous scars. Although redwood compartmentalizes rot as it grows over it, the dead cambium will rot wood interior to it. The effects of dead cambium introducing defect are immediate. As the water transport cells break down, the sapwood dries out and is therefore susceptible to dry rot and termite attacks.

As the trees began to grow, the cracks in the bark where cambium had burned began to separate. Now, two years after the fire, the bark plates have separated where cambium died and you can see the cambium growing over the dead wood layer and re-sealing the perimeter of the tree. Badly burned trees developed a variety of fungus and lichen on the scorched bark, giving clues about the extent of internal damage.

There was increased burn damage in certain environmental settings such as: where ladder fuels were present, next to a more flammable vegetation type, on ridges, in topographic chimneys, in dense stands of un-thinned trees and where there was a heavy duff layer, legacy stumps, or lots of downed wood. Canopy damage ranged from an un-phased crown to all but the biggest limbs completely consumed in a crown fire. Severely burned trees did not re-sprout from 
the limbs, but only from the bole, like a bottle-brush. Where new limbs or tops are formed, the dead wood will be subsumed in the new growth, creating a weak spot in the wood.

Most second growth redwood trees that have experienced an intense wildfire in the past have an interior cylinder of rot. Using the Department of Agriculture, Forest Service Log Scaling and Grading Rules, that defect is "squared out" in order to account for waste when manufacturing dimensional lumber. The quality of the wood going into the mill is very important for the end result of producing sound building materials. Compounded defect from multiple fires would severely impact the manufacturing of high grade lumber. Experience dictates that defect levels elevated above $20 \%$ have dramatic consequences for the net return of a timber harvest for the landowner.

\section{Adaptive management}

During the first fall after the fire, a small area (4 acres) was salvage logged with ground based equipment to see the extent of the burn damage. Initiating the salvage effort offered an opportunity for foresters to verify the external indicators used to determine defect. Once the trees were cut, the dead cambium sections were discernible in the cross-section because the usually fuzzy, fibrous inner bark becomes smooth and sometimes separated from the wood when it is dead.

The rot from the fresh fire scars had already started. Landowners wishing to grow sound trees for sustainable harvest had to react. More damage was sustained to the timber resource than was recouped in the salvage. Trees left with fire scaring and dead wood are more vulnerable to fire and insect attack going into the future. Due to the practice of leaving the healthiest residual trees to retain structure for wildlife and maintain microsite characteristics, many trees were left. It was not inexpensive to log, nor did it produce windfall profits. Compounding the loss, the low profitability in Douglas-fir markets necessitated that many thousands of dead Douglas-fir trees be left standing. Redwood seedlings were under-planted in some of these areas.

\section{Helicopter salvage harvest}

Multiple land managers elected to proceed with a salvage harvest by helicopter. Helicopter harvesting is extremely expensive, but avoids the ground disturbance of conventional harvest methods, that can occur with tractor logging. The salvage operation was a long-term land management decision to "cut our losses" and establish better wood quality in the future. Helicopter harvesting affects the bottom line, but weighing all decision-making factors, it made sense for the initial salvage effort due to the resource protection it affords as a result of the minimal ground impact. Other factors affecting the decision to fly included the relative inaccessibility of the ground, seasonal restrictions for sensitive species, the helicopters availability, and the desire to recover the damaged wood quickly.

\section{Mortality assessment}

The SPR NTMP was approved in June of 2008. Encompassed in this document is the sustainability analysis (SA) required by the Forest Practice Rules to demonstrate movement toward a fully regulated state of harvest over time. In essence, this means a "cut what you grow" type system focused on the long term sustained yield of forest products. Once the Lockheed Fire burned over the majority of the SPR NTMP area the SA had to be re-evaluated. What determines tree mortality for the purpose of amending the NTMP's sustainability analysis following wildfire? 


\section{Mortality assessment method}

SPR's Continuous Forest Inventory (CFI) samples approximately two to three percent of the forested area, probably considered by most to be a lower sample for most forest inventories. Where the SPR CFI system excels is in sampling intensity within the plot, measuring all trees in the plot down to one inch Diameter at Breast Height (DBH). Each tree is numbered and has a distance and bearing recorded to plot center so it can be tracked over time. Last re-measurement of the 83 CFI plots in the burn area was 2008 and 2003. This means an excellent record of tree condition prior to the fire now exists.

The purpose of the mortality assessment was to test a set of guidelines based on professional opinion and available scientific literature for the forester or land manager to utilize to evaluate conifer and hardwood mortality levels immediately following wildfire.

The mortality assessment began with an initial evaluation in fall of 2009. The data listed below was gathered on each tree in the plot and applied to Tables $1-3$ (provided below) to evaluate tree mortality:

1. Percent of crown remaining on each tree to one inch DBH

2. Percent of crown sprouting on each tree to one inch $\mathrm{DBH}$

3. Basal sprouting? Y/N

4. Percent of root system and cambium quadrants (4 possible) destroyed by fire (not recorded, but evaluated)

5. Will the tree live or die? $\mathrm{Y} / \mathrm{N}$

6. $10^{\text {th }}$ acre plot regeneration less than one inch $\mathrm{DBH}$

7. Plot photos in cardinal directions

The tables below state the characteristics that were assessed on each tree to determine whether the tree would live or die. For example, look at Table 2, Tanoak:

- zero percent canopy remaining

- less than five percent canopy sprouting

- missing more than $66 \%$ of its root system

- Two quadrants of cambium destroyed by fire

- The tree was considered dead. 
Table 1 - Thresholds for determining tree mortality: 1 - 8 inch DBH classes (1.0” - 8.9”)

\begin{tabular}{|l|c|c|c|c|}
\hline Tree Species & $\begin{array}{l}\text { Percent canopy } \\
\text { remaining }\end{array}$ & $\begin{array}{l}\text { Percent canopy } \\
\text { sprouting }\end{array}$ & $\begin{array}{l}\text { Percent of root } \\
\text { system missing }\end{array}$ & $\begin{array}{l}\text { Cambium quadrants } \\
\text { destroyed by fire }\end{array}$ \\
\hline Redwood (RW) & $0 \%$ & $10 \%$ & $33 \%$ & 1 \\
\cline { 2 - 5 } $\begin{array}{l}\text { California nutmeg (CN) } \\
\text { Live oak (LO) }\end{array}$ Tanoak (TO) & $0 \%$ & $10 \%$ & $33 \%$ & 1 \\
\cline { 2 - 5 } Red alder (RA) & $0 \%$ & $10 \%$ & $33 \%$ & 1 \\
\cline { 2 - 5 } California bay laurel (CL) & $0 \%$ & $10 \%$ & $33 \%$ & 1 \\
\cline { 2 - 5 } Pacific madrone (PM) & $0 \%$ & $10 \%$ & $33 \%$ & 1 \\
\cline { 2 - 5 } Big leaf maple (BM) & $0 \%$ & $10 \%$ & $33 \%$ & 1 \\
\cline { 2 - 5 } $\begin{array}{l}\text { Douglas-fir (DF) } \\
\text { Monterey pine (MP) } \\
\text { Knobcone pine (KP) }\end{array}$ & $0 \%$ & $10 \%$ & $33 \%$ & 1 \\
\cline { 2 - 5 } & $0 \%$ & $10 \%$ & $33 \%$ & 1 \\
\cline { 2 - 5 } & $70 \%$ & N/A & $33 \%$ & 1 \\
\hline
\end{tabular}

Table 2 - Thresholds for determining tree mortality: 9 - 16 inch DBH (9.0” - 16.9”)

\begin{tabular}{|l|c|c|c|c|}
\hline Tree Species & $\begin{array}{l}\text { Percent canopy } \\
\text { remaining }\end{array}$ & $\begin{array}{l}\text { Percent canopy } \\
\text { sprouting }\end{array}$ & $\begin{array}{l}\text { Percent of root } \\
\text { system missing }\end{array}$ & $\begin{array}{l}\text { Cambium quadrants } \\
\text { destroyed by fire }\end{array}$ \\
\hline Redwood (RW) & $0 \%$ & $5 \%$ & $66 \%$ & 2 \\
\cline { 2 - 5 } $\begin{array}{l}\text { California nutmeg (CN) } \\
\text { Live oak (LO) } \\
\text { Tanoak (TO) }\end{array}$ Red alder (RA) & $0 \%$ & $5 \%$ & $50 \%$ & 2 \\
\cline { 2 - 5 } California bay laurel (CL) & $0 \%$ & $5 \%$ & $66 \%$ & 2 \\
\cline { 2 - 5 } Pacific madrone (PM) & $0 \%$ & $5 \%$ & $66 \%$ & 2 \\
\cline { 2 - 5 } Big leaf maple (BM) & $0 \%$ & $5 \%$ & $50 \%$ & 2 \\
\cline { 2 - 5 } $\begin{array}{l}\text { Douglas-fir (DF) } \\
\text { Monterey pine (MP) } \\
\text { Knobcone pine (KP) }\end{array}$ & $0 \%$ & $5 \%$ & $50 \%$ & 2 \\
\cline { 2 - 5 } & $0 \%$ & $5 \%$ & $50 \%$ & 1 \\
\cline { 2 - 5 } & $60 \%$ & N/A & $33 \%$ & 1 \\
\hline
\end{tabular}

Table 3 - Thresholds for determining tree mortality: 17.0+ inch DBH classes (17.0”+)

\begin{tabular}{|l|c|c|c|c|}
\hline Tree Species & $\begin{array}{l}\text { Percent canopy } \\
\text { remaining }\end{array}$ & $\begin{array}{l}\text { Percent canopy } \\
\text { sprouting }\end{array}$ & $\begin{array}{l}\text { Percent of root } \\
\text { system missing }\end{array}$ & $\begin{array}{l}\text { Cambium quadrants } \\
\text { destroyed by fire }\end{array}$ \\
\hline \multirow{2}{*}{$\begin{array}{l}\text { Redwood (RW) } \\
\text { California nutmeg (CN) }\end{array}$} & $0 \%$ & $0 \%$ & $66 \%$ & 3 \\
\cline { 2 - 5 } Live oak (LO) & $0 \%$ & $0 \%$ & $50 \%$ & 2 \\
\cline { 2 - 5 } $\begin{array}{l}\text { Tanoak (TO) } \\
\text { Red alder (RA) }\end{array}$ California bay laurel (CL) & $0 \%$ & $0 \%$ & $66 \%$ & 3 \\
\cline { 2 - 5 } $\begin{array}{l}\text { Pacific madrone (PM) } \\
\text { Big leaf maple (BM) }\end{array}$ & $0 \%$ & $0 \%$ & $66 \%$ & 2 \\
\cline { 2 - 5 } $\begin{array}{l}\text { Douglas-fir (DF) } \\
\text { Monterey pine (MP) } \\
\text { Knobcone pine (KP) }\end{array}$ & $0 \%$ & $0 \%$ & $50 \%$ & 2 \\
\cline { 2 - 5 } & $0 \%$ & $0 \%$ & $50 \%$ & 2 \\
\cline { 2 - 5 } & $0 \%$ & $0 \%$ & $33 \%$ & 2 \\
\hline
\end{tabular}

Each tree was evaluated, qualitatively, around these guidelines, but if the tree met all of the thresholds by DBH category it was considered dead. 


\section{Mortality assessment results}

The mortality assessment began with an initial evaluation in fall of 2009 These same 83 plots (2877 trees) were re-evaluated in spring of 2010 and spring of 2011 to determine whether the initial mortality assessment in fall of 2009 was correct. Overall weighted average for percent accuracy to date is 89.3 percent. See Tables $4-6$ below for more detailed information on species, diameter class, percent accuracy and sample size.

Table 4 - Accuracy of tree mortality assessment: 1 - 8 inch DBH

\begin{tabular}{|l|r|r|}
\hline Tree Species & Percent accuracy & Sample size \\
\hline Redwood (RW) & $90.4 \%$ & 470 \\
\cline { 2 - 3 } California nutmeg (CN) & $58.3 \%$ & 12 \\
\cline { 2 - 3 } Live oak (LO) & $85.9 \%$ & 207 \\
\cline { 2 - 3 } Tanoak (TO) & $88.0 \%$ & 302 \\
\cline { 2 - 3 } Red alder (RA) & $62.5 \%$ & 8 \\
California bay laurel (CL) & $84.0 \%$ & 119 \\
\cline { 2 - 3 } Pacific madrone (PM) & $77.0 \%$ & 61 \\
\cline { 2 - 3 } Big leaf maple (BM) & $0.0 \%$ & 290 \\
\cline { 2 - 3 } Douglas-fir (DF) & $96.2 \%$ & 17 \\
Monterey pine (MP) & $82.3 \%$ & 1488 \\
\cline { 2 - 3 } Knobcone pine (KP) & $0.0 \%$ & $\mathbf{8 8 . 7 \%}$ \\
\hline Weighted average & & \\
\cline { 2 - 3 }
\end{tabular}

Table 5 - Accuracy of tree mortality assessment: 9-16 DBH

\begin{tabular}{|l|r|r|}
\hline Tree Species & Percent accuracy & Sample size \\
\hline Redwood (RW) & $93.2 \%$ & 223 \\
\cline { 2 - 3 } California nutmeg (CN) & $80.0 \%$ & 5 \\
\cline { 2 - 3 } Live oak (LO) & $88.0 \%$ & 150 \\
\cline { 2 - 3 } Tanoak (TO) & $83.9 \%$ & 181 \\
\cline { 2 - 3 } Red alder (RA) & $0.0 \%$ & 0 \\
\cline { 2 - 3 } California bay laurel (CL) & $66.0 \%$ & 50 \\
\cline { 2 - 3 } Pacific madrone (PM) & $73.0 \%$ & 15 \\
\cline { 2 - 3 } Big leaf maple (BM) & $0.0 \%$ & 0 \\
\cline { 2 - 3 } Mouglas-fir (DF) & $97.5 \%$ & 122 \\
\cline { 2 - 3 } Konterey pine (MP) & $78.9 \%$ & 19 \\
\cline { 2 - 3 } Knobcone pine (KP) & $100.0 \%$ & 768 \\
\hline Weighted average & $\mathbf{8 8 . 1 \%}$ & \\
\hline
\end{tabular}


Table 6 - Accuracy of tree mortality assessment: 17.0+ inch DBH

\begin{tabular}{|l|r|r|}
\hline Tree Species & Percent accuracy & Sample size \\
\hline Redwood (RW) & $97.7 \%$ & 271 \\
\cline { 2 - 3 } California nutmeg (CN) & $66.0 \%$ & 3 \\
\cline { 2 - 3 } Live oak (LO) & $89.1 \%$ & 74 \\
\cline { 2 - 3 } Tanoak (TO) & $95.4 \%$ & 66 \\
\cline { 2 - 3 } Red alder (RA) & $28.6 \%$ & 7 \\
\cline { 2 - 3 } California bay laurel (CL) & $55.0 \%$ & 9 \\
\cline { 2 - 3 } Pacific madrone (PM) & $50.0 \%$ & 6 \\
\cline { 2 - 3 } Big leaf maple (BM) & $0.0 \%$ & 0 \\
Douglas-fir (DF) & $90.5 \%$ & 180 \\
\cline { 2 - 3 } Monterey pine (MP) & $100.0 \%$ & 3 \\
\cline { 2 - 3 } Knobcone pine (KP) & $100.0 \%$ & 621 \\
\hline Weighted average & $\mathbf{9 2 . 4 \%}$ & \\
\hline
\end{tabular}

\section{Mortality assessment discussion}

The mortality assessment was led in the field by the same SPR forestry technicians, for all three evaluation periods maintaining continuity in an assessment that had a manageable level of subjectivity.

Following the initial evaluation of the 83 plots in Fall 2009 portions of the burn area were salvaged harvested in 2010 and harvested under the SPR NTMP in 2011. Forestry technicians were very systematic at determining if trees evaluated in 2009 were affected by harvesting activities. If so, those trees were removed from the sample for the purposes of this test.

Accuracy for the mortality assessment tables in the first two evaluation periods (Spring 2010 and Spring 2011) following the initial evaluation in Fall 2009 at 89.3 percent was strong, but the mortality assessment table faltered a little in the thinner bark species; California nutmeg, red alder, California bay laurel, Pacific madrone, and big leaf maple in the mid (9" - 16” DBH) and upper (17.0+" DBH) diameter classes. Based on the data set, reducing the "Cambium quadrants destroyed by fire" to "one" in both the mid and upper diameter classes would increase accuracy. These trees did not withstand as much cambial damage as expected.

The mortality assessment showed very strong results in redwood, tanoak, live oak, Douglas-fir, Monterey pine, and Knobcone pine to date. Adjustments to increase accuracy for these species would likely require additional data on other burn characteristics such as scorch height and bark thickness.

\section{Conclusion}

A combination of factors affected the decision making process in regards to what trees are harvested that will encourage regeneration of managed forestland following wildfire. One or more of the following criteria affecting an individual tree may be reason to suspect that the tree is substantially damaged and will sustain negative impacts from the fire: cambium damage on multiple sides of the tree, extensive root damage with voids under the tree, extensive crown consumption or scorching that kills limbs, and significant prior defect combined with damage. This is an ongoing learning experience that will be refined as time passes and managed forestland continues to burn and be harvested.

The process of damage evaluation provided significant direction to determine an applied set of quantitative criteria to develop the mortality assessment. It is clear that more years need to pass to understand the full effects that the Lockheed Fire, compounded by the Pine Mountain Fire, had on the forested area in the Scotts Creek watershed. Follow-up surveys will continue visiting the 2877 trees each spring to see if the mortality assessment table continues to hold its 
accuracy. There is also movement from Cal Poly San Luis Obispo to begin sampling scorch height and bark thickness in addition to the mortality assessment in an attempt to create a local wildfire mortality equation.

\section{Literature cited}

Wagener, W.W. 1961. Guidelines for estimating the survival of fire-damaged trees in California.

Miscellaneous paper-60, Pacific Southwest Forest and Ranch Experiment Station, Berkeley, CA. 11 p. 


\section{Appendix B}

Power Point Presentation from the 2011 Redwood Symposium

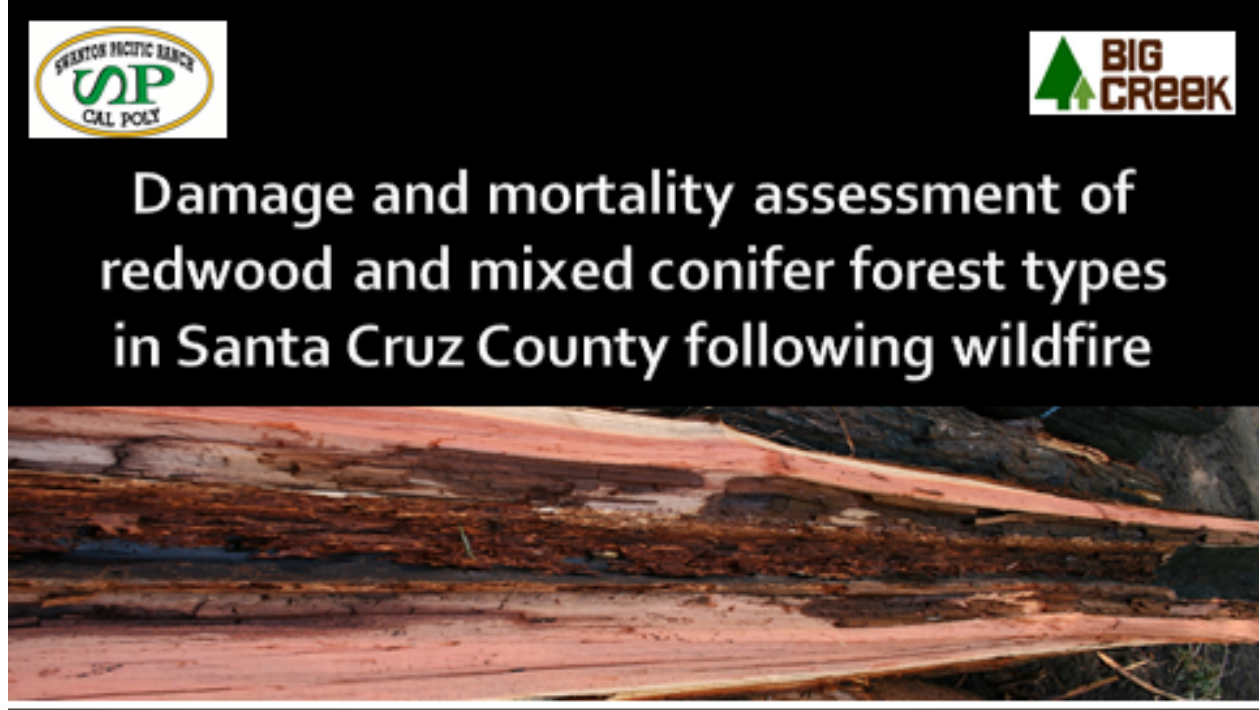

Steve Auten, Resource Manager, Cal Poly, Swanton Pacific Ranch, RPF \# 2734

Nadia Hamey, Forester, Big Creek Lumber Company, RPF \# 2788

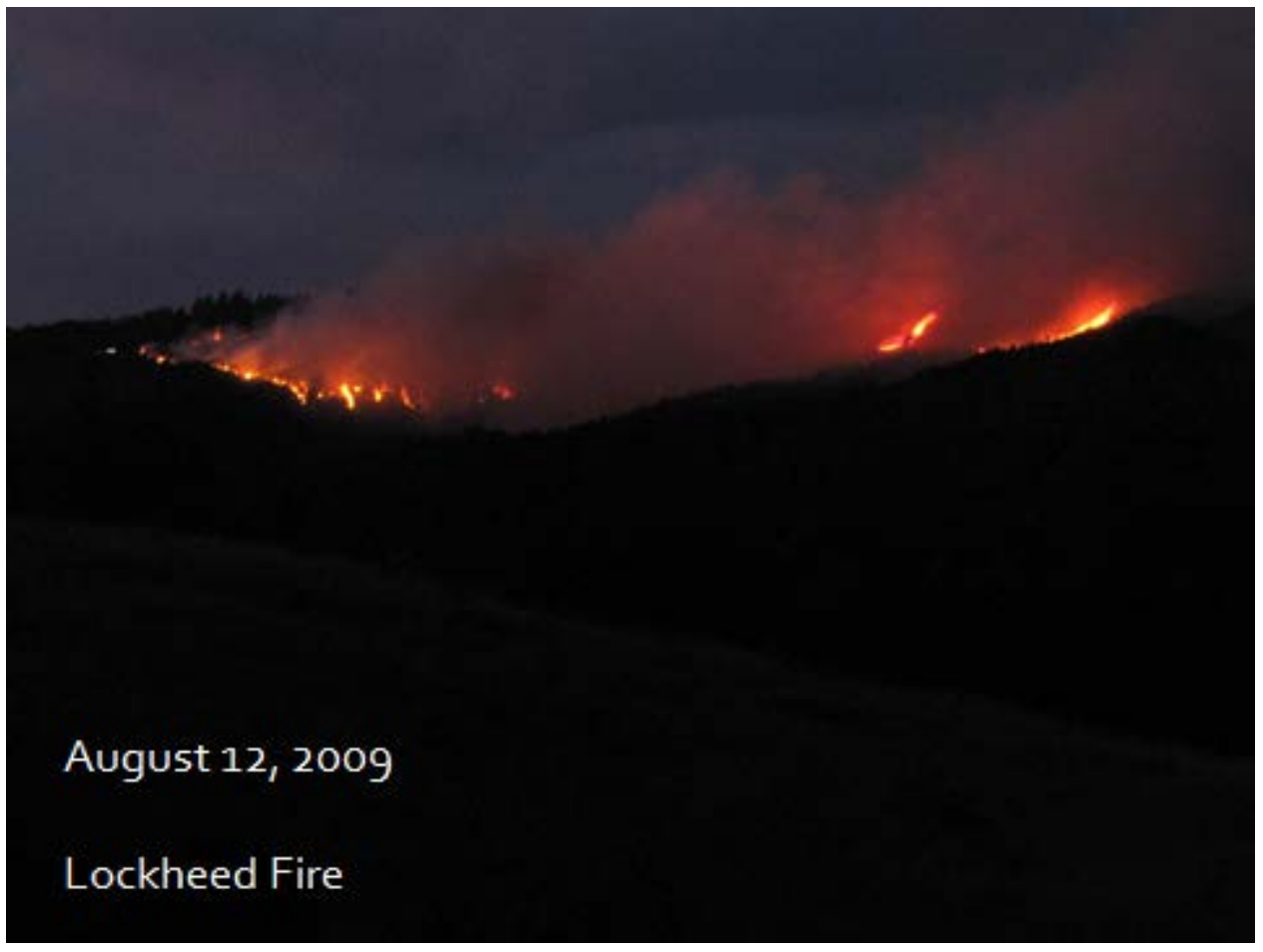



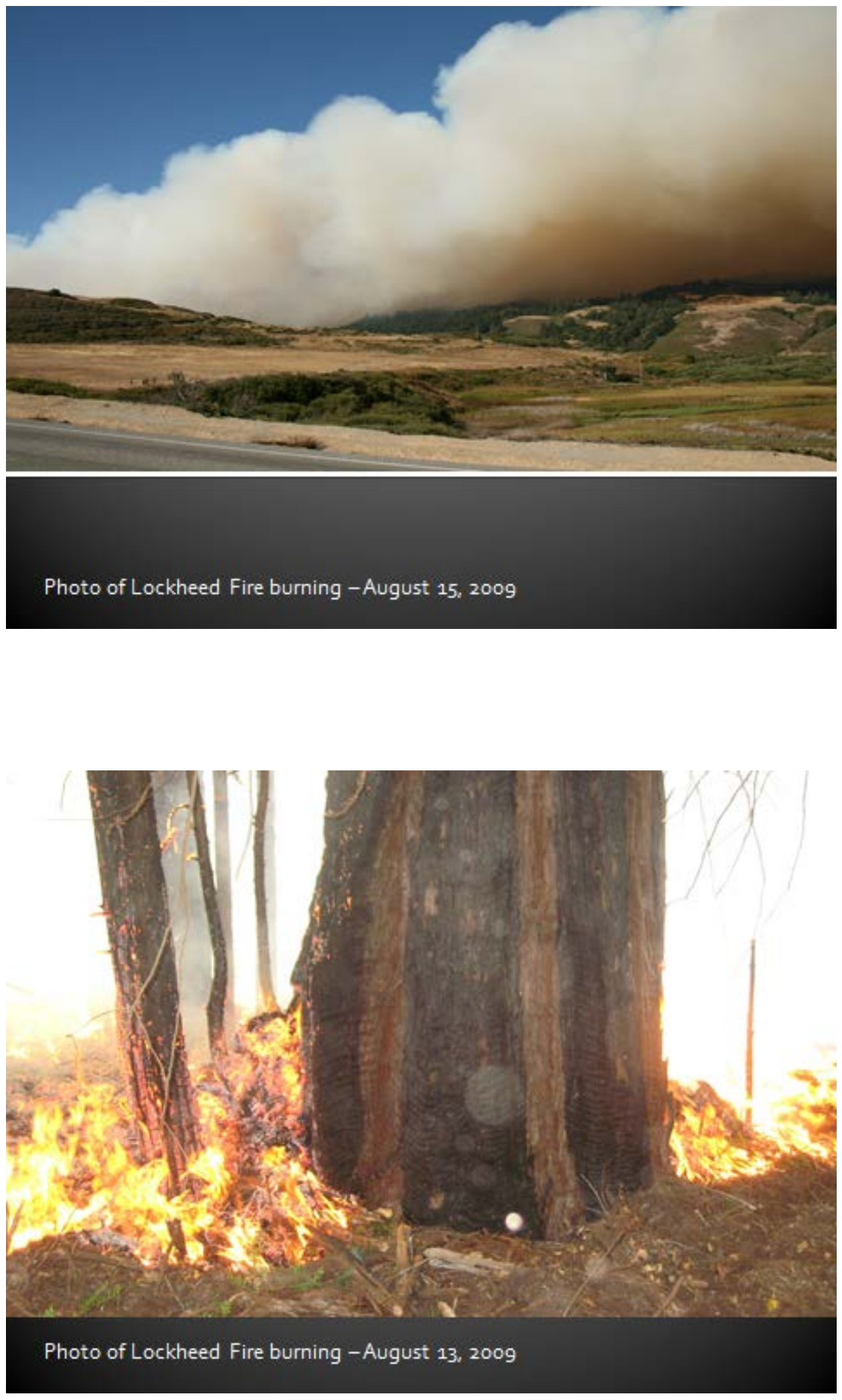

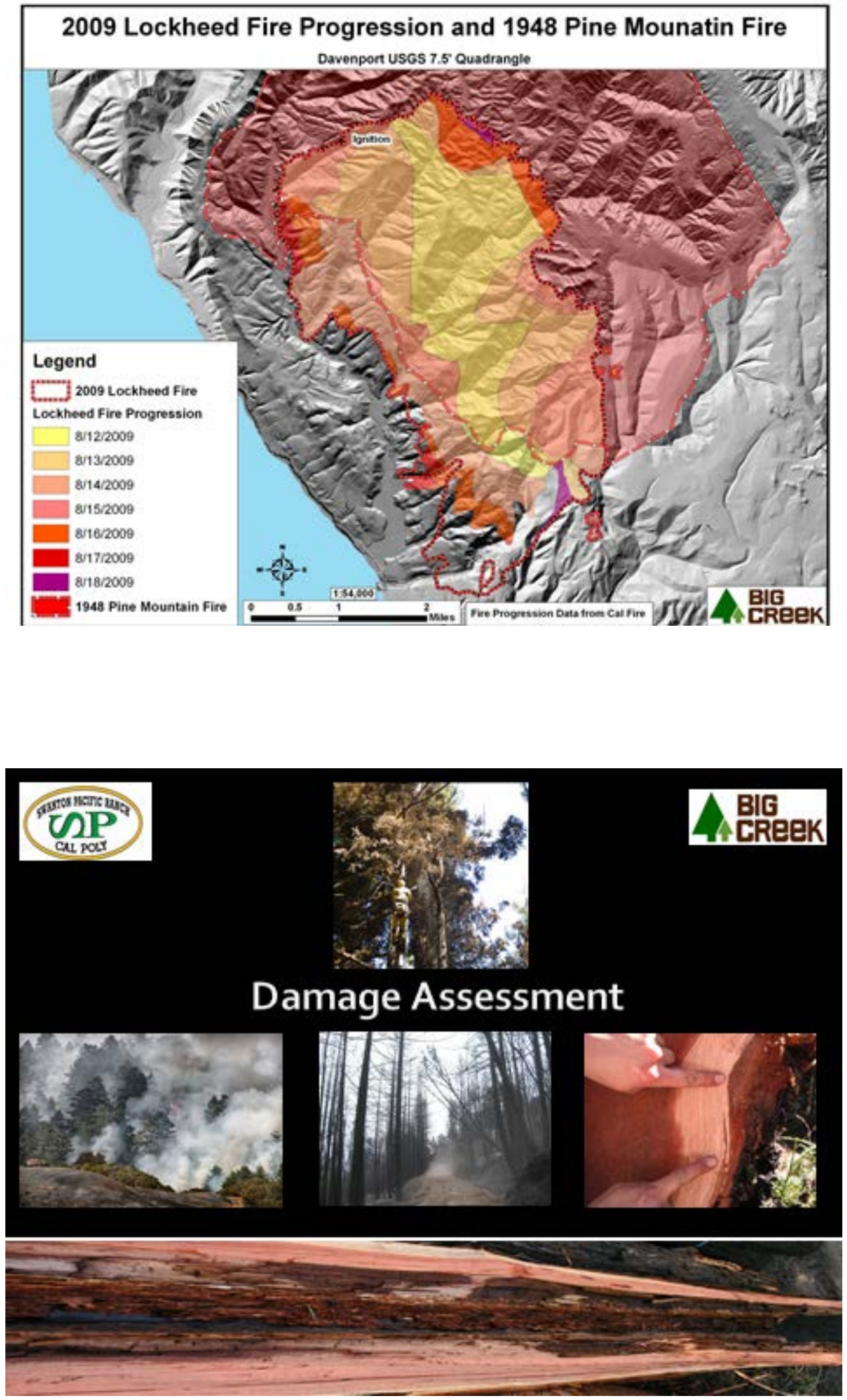

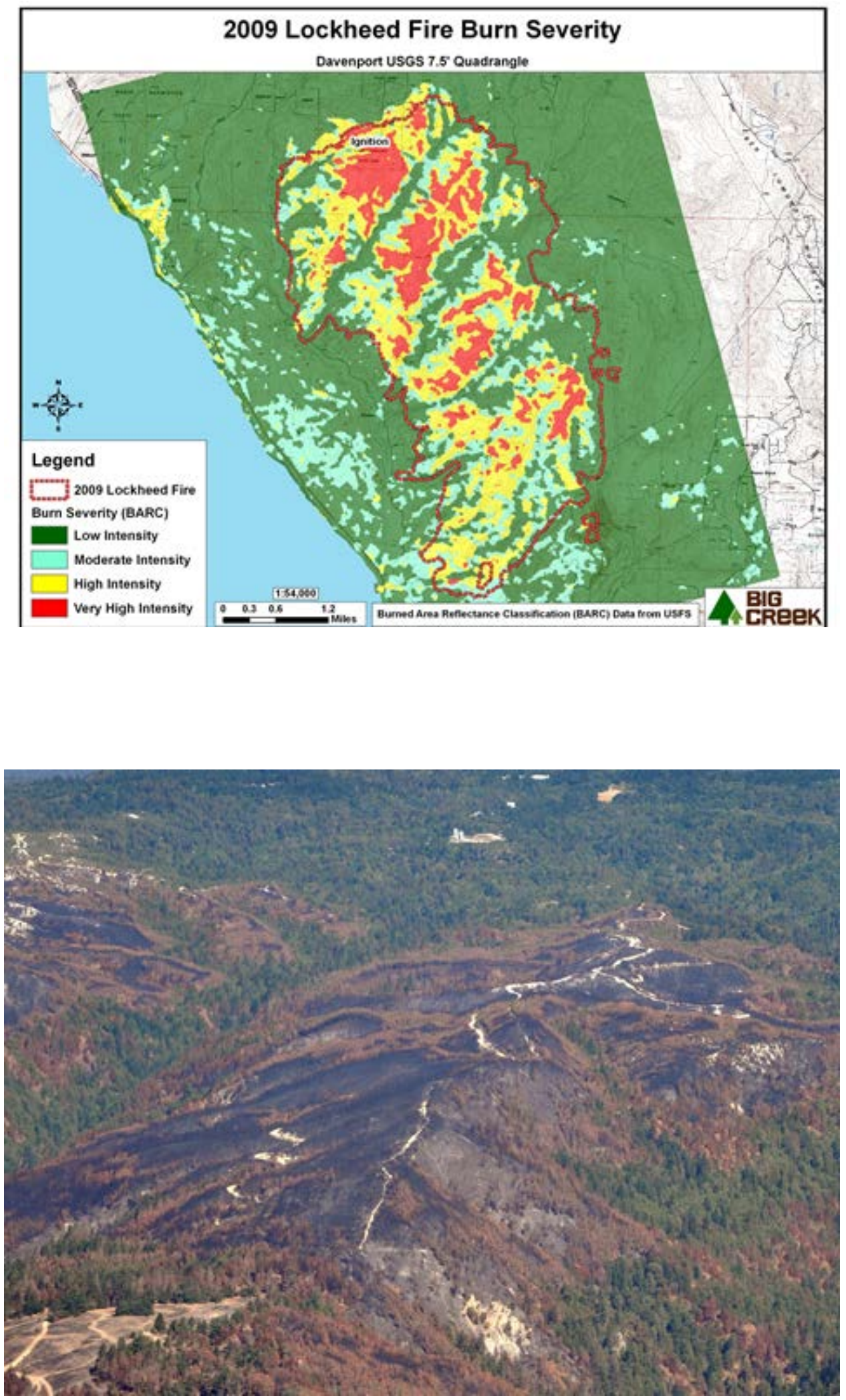

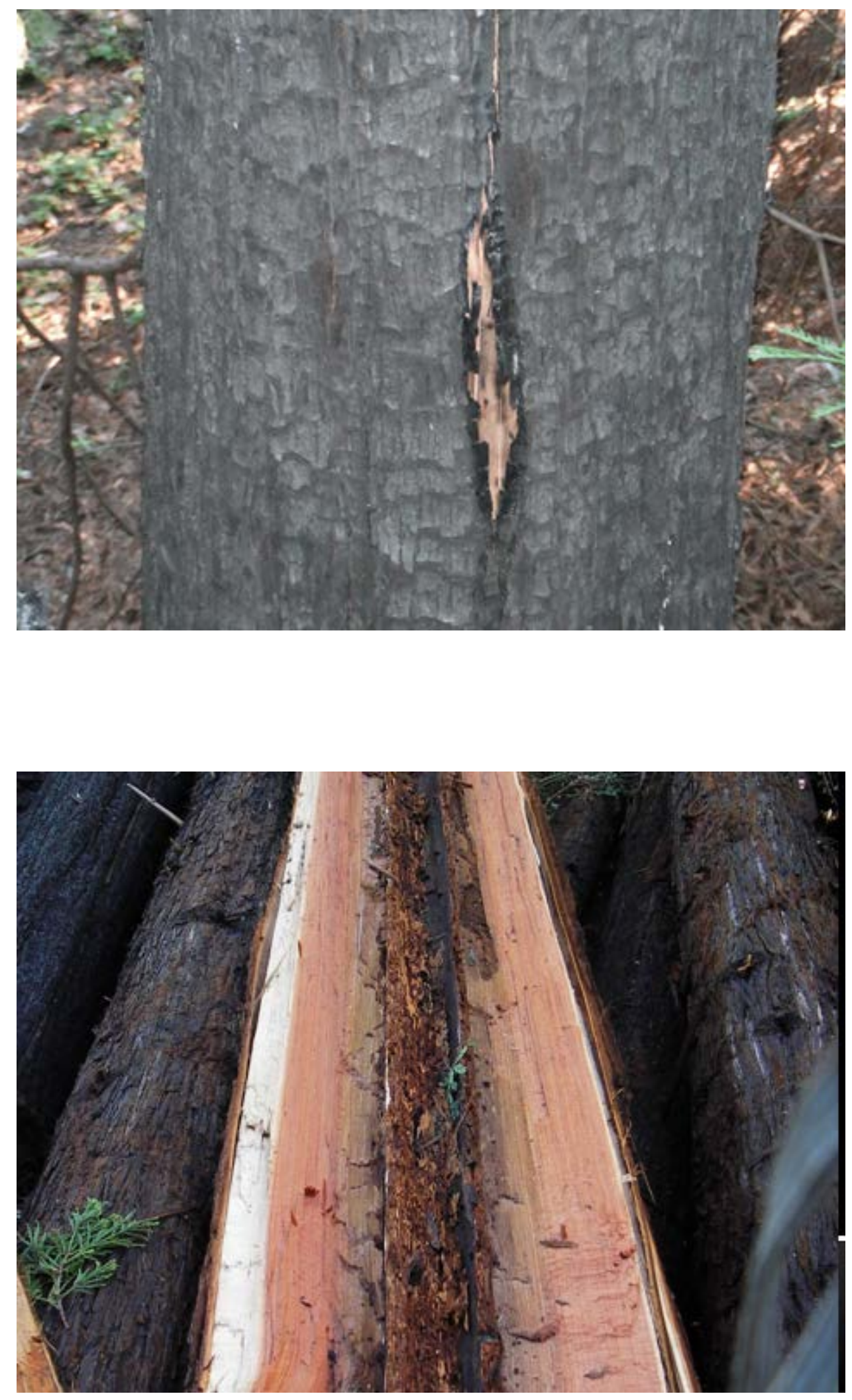


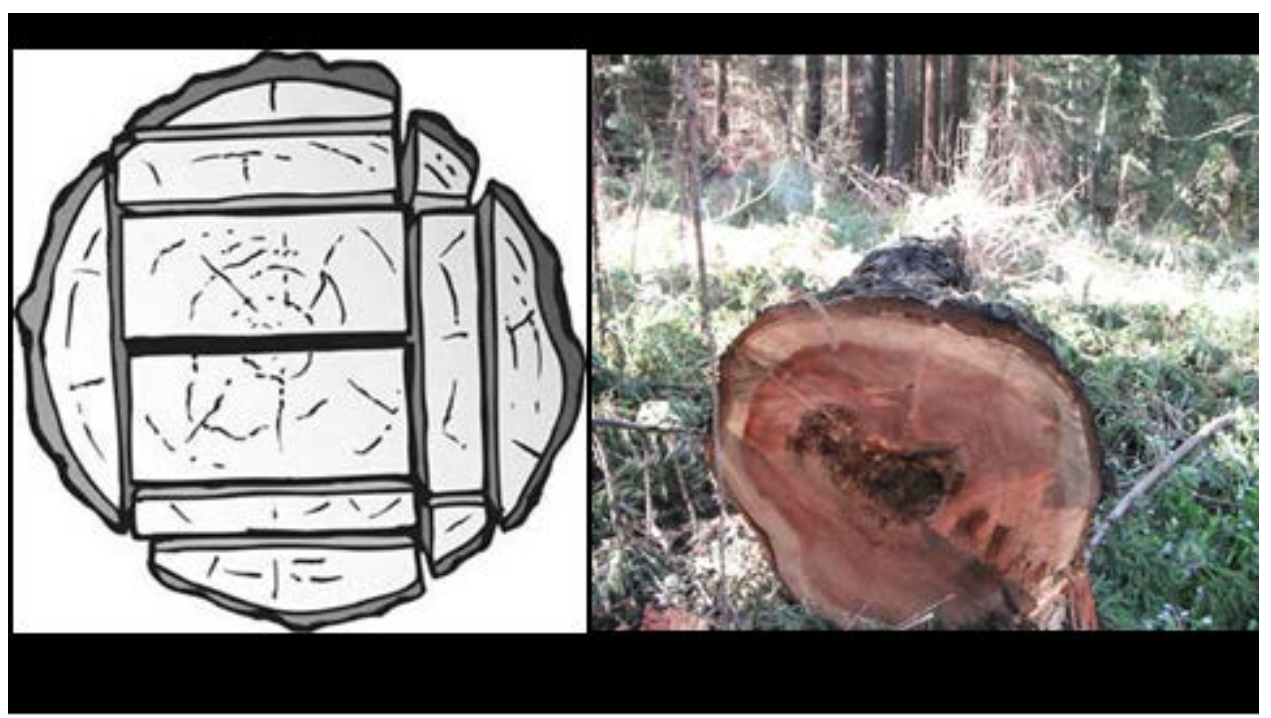

Diagram showing number of 1 inch boards that can be cut from a specific log

Interior defect from a fire is "squared out" and reduces net volume significantly.

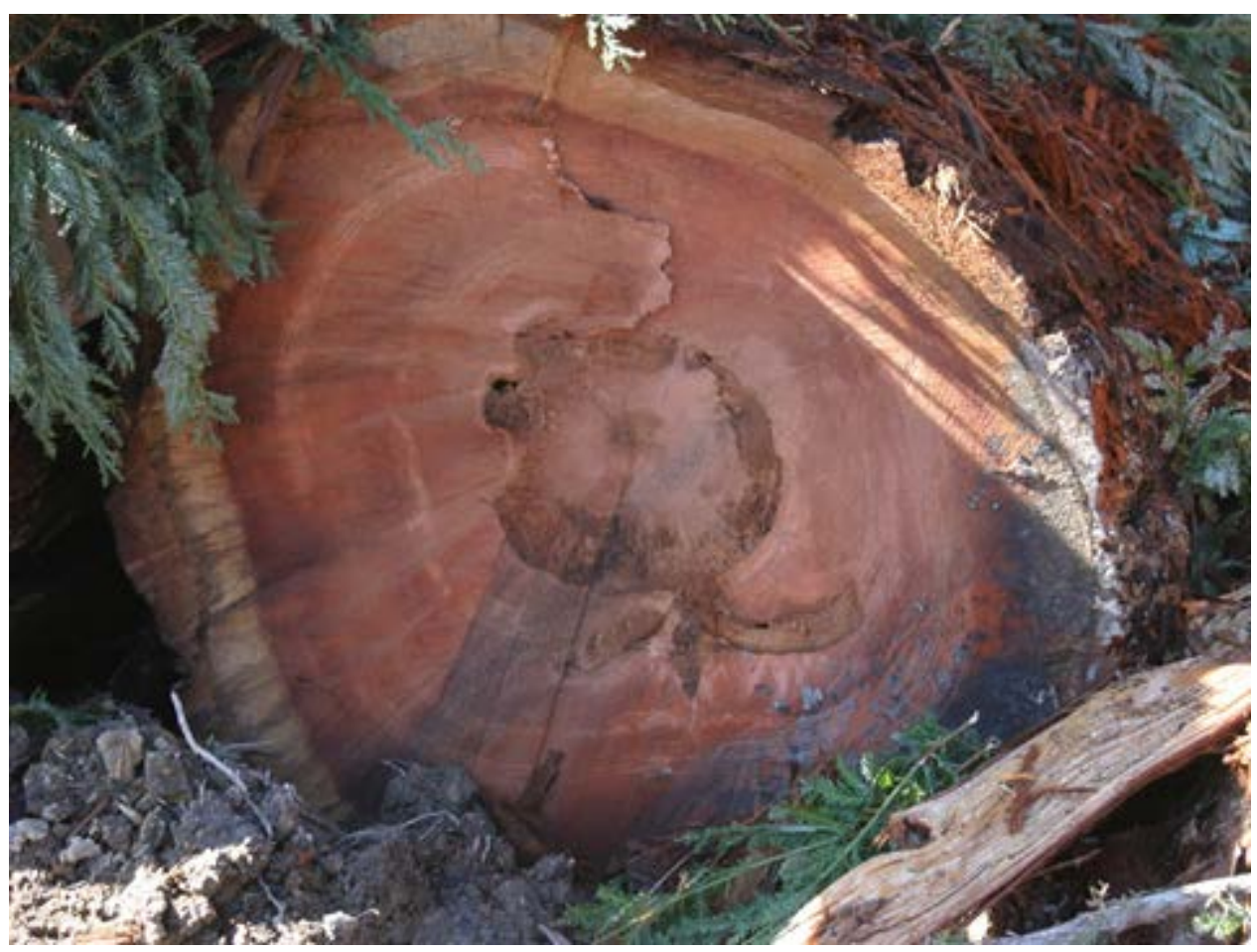



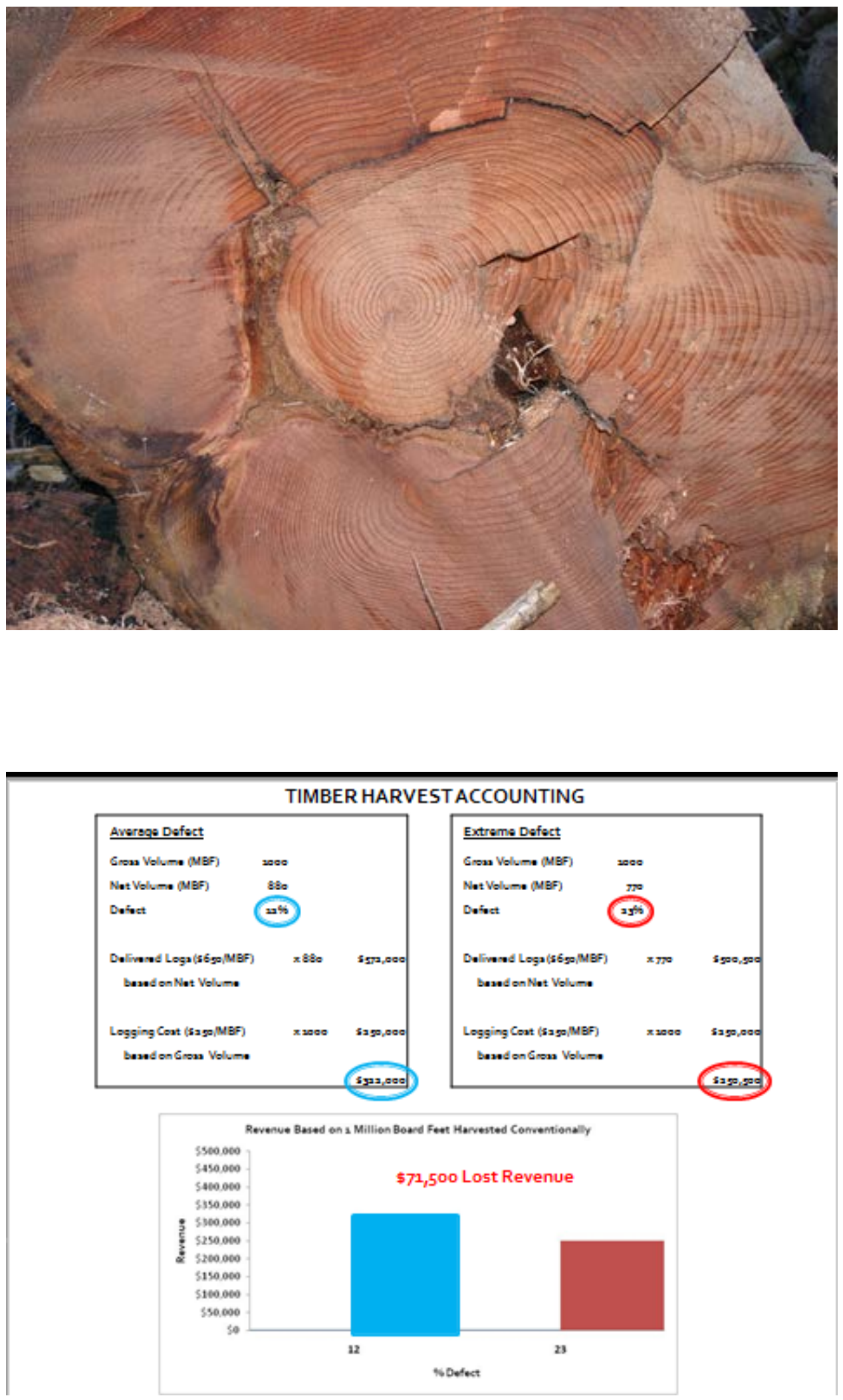

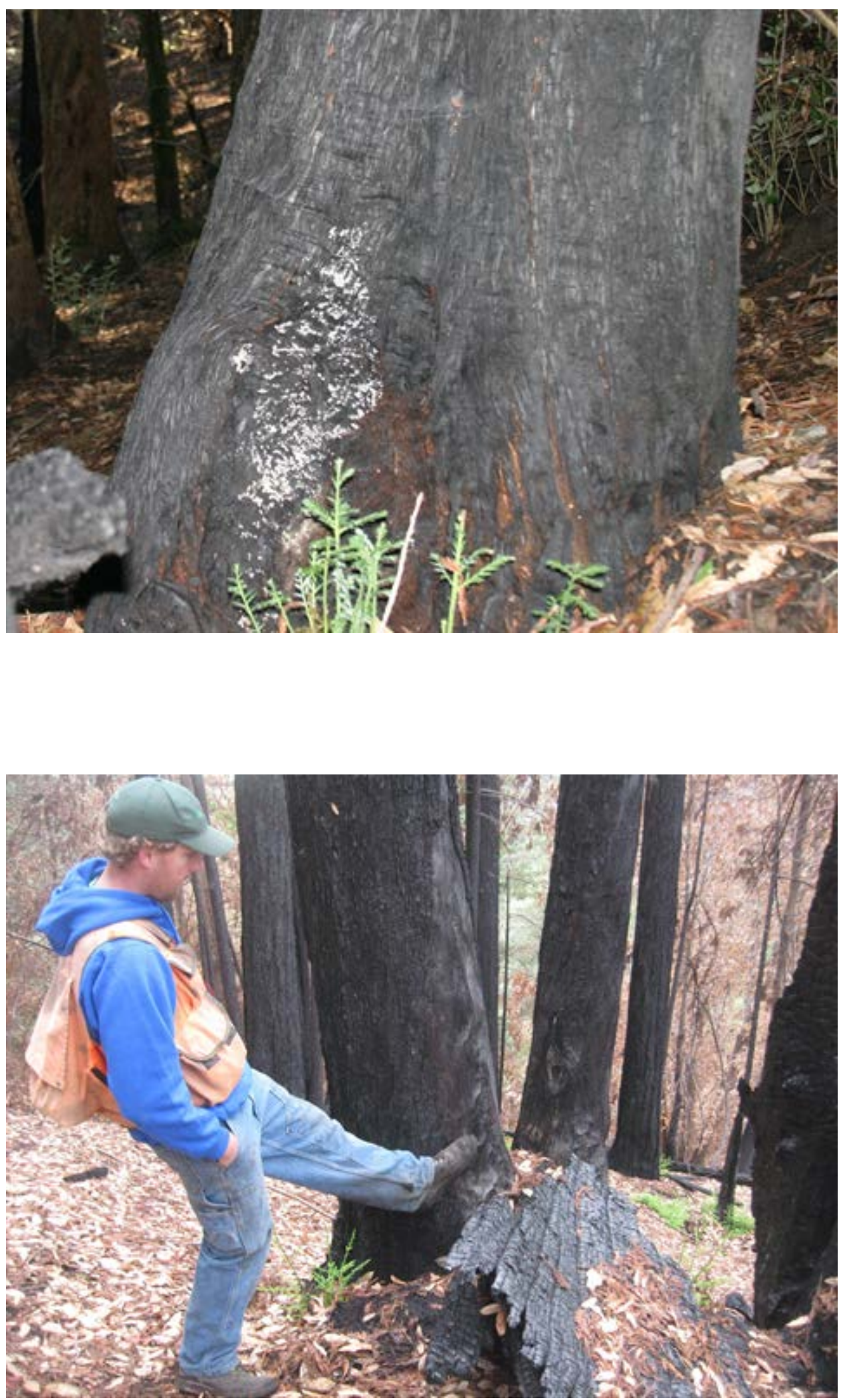

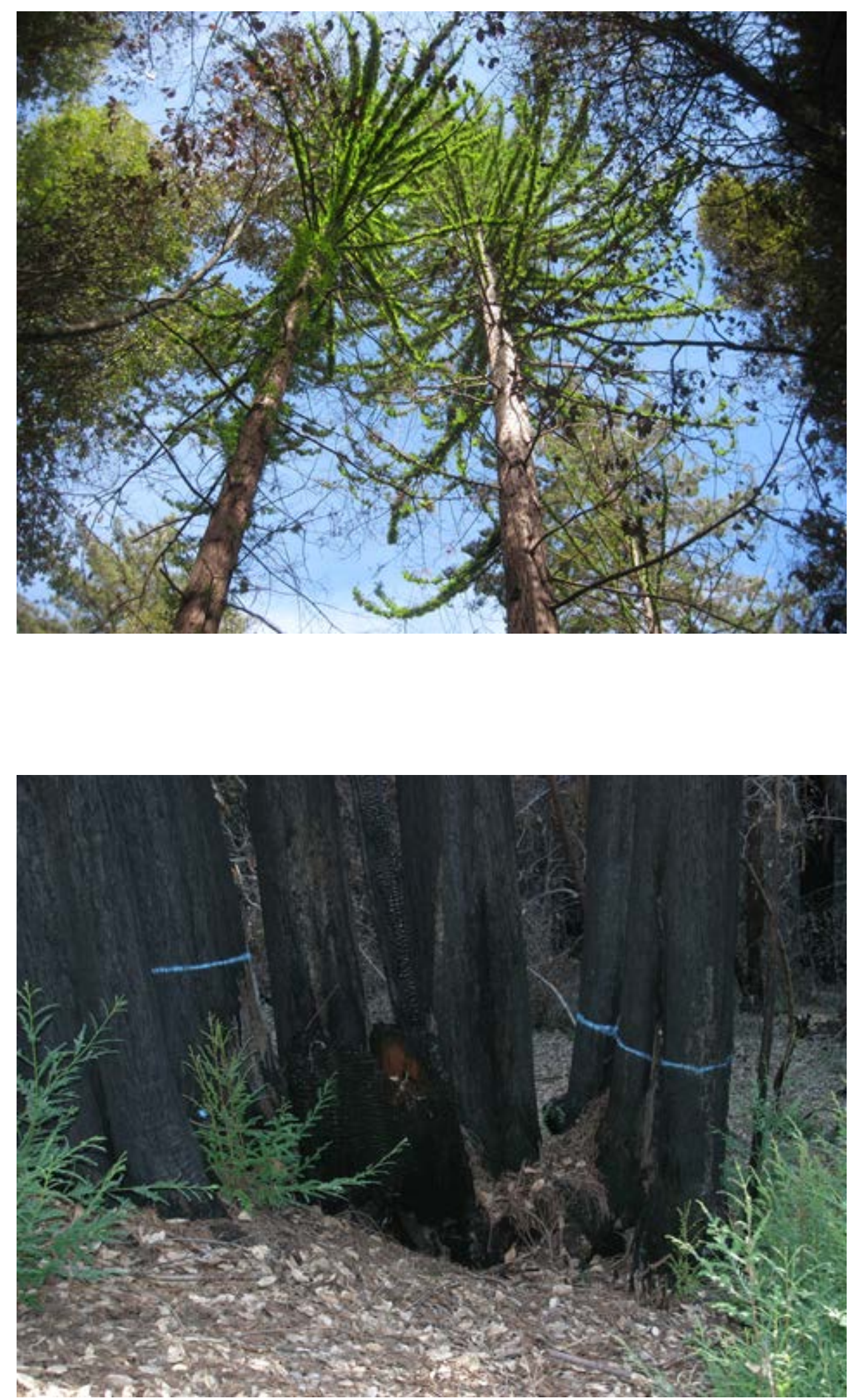

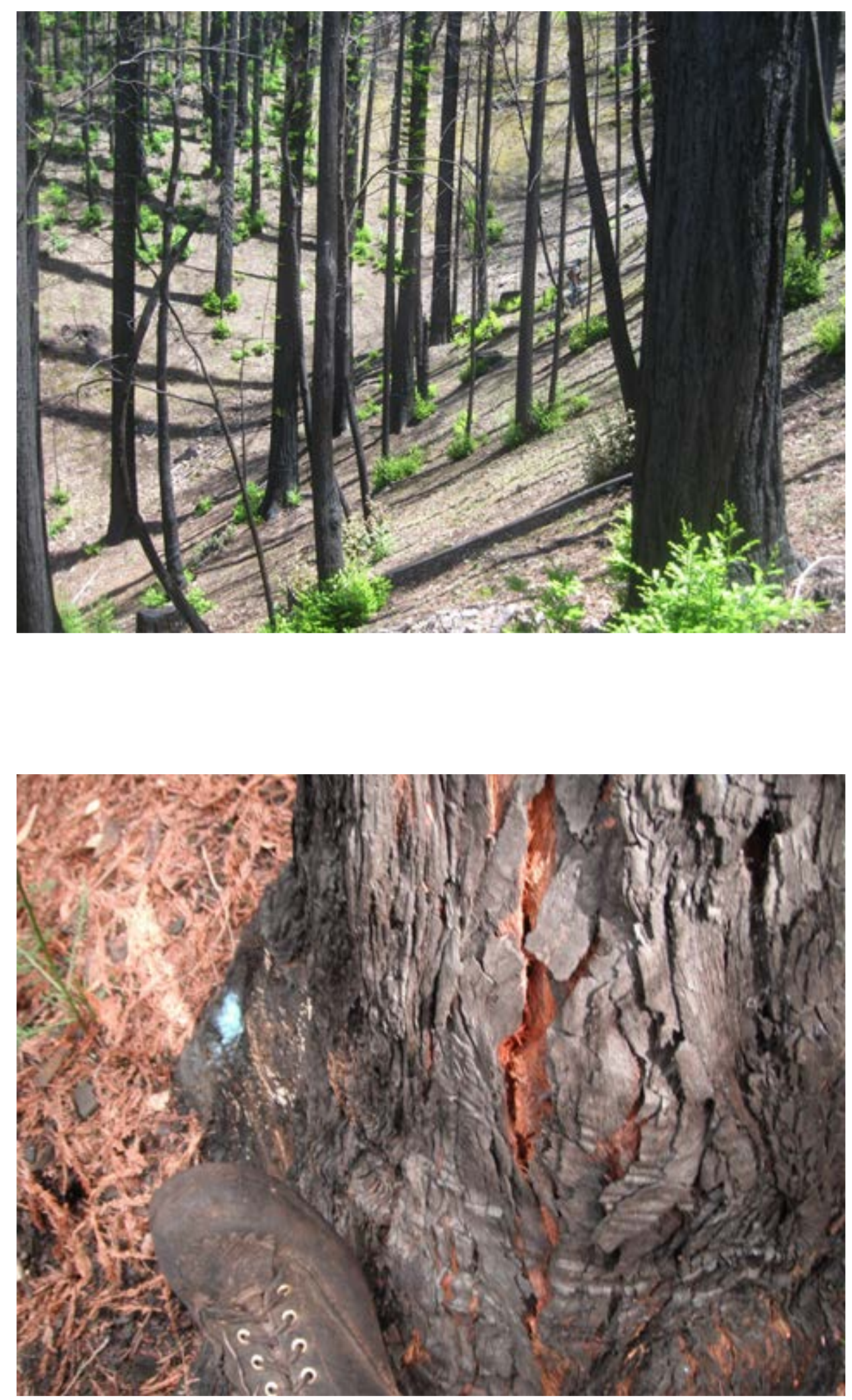

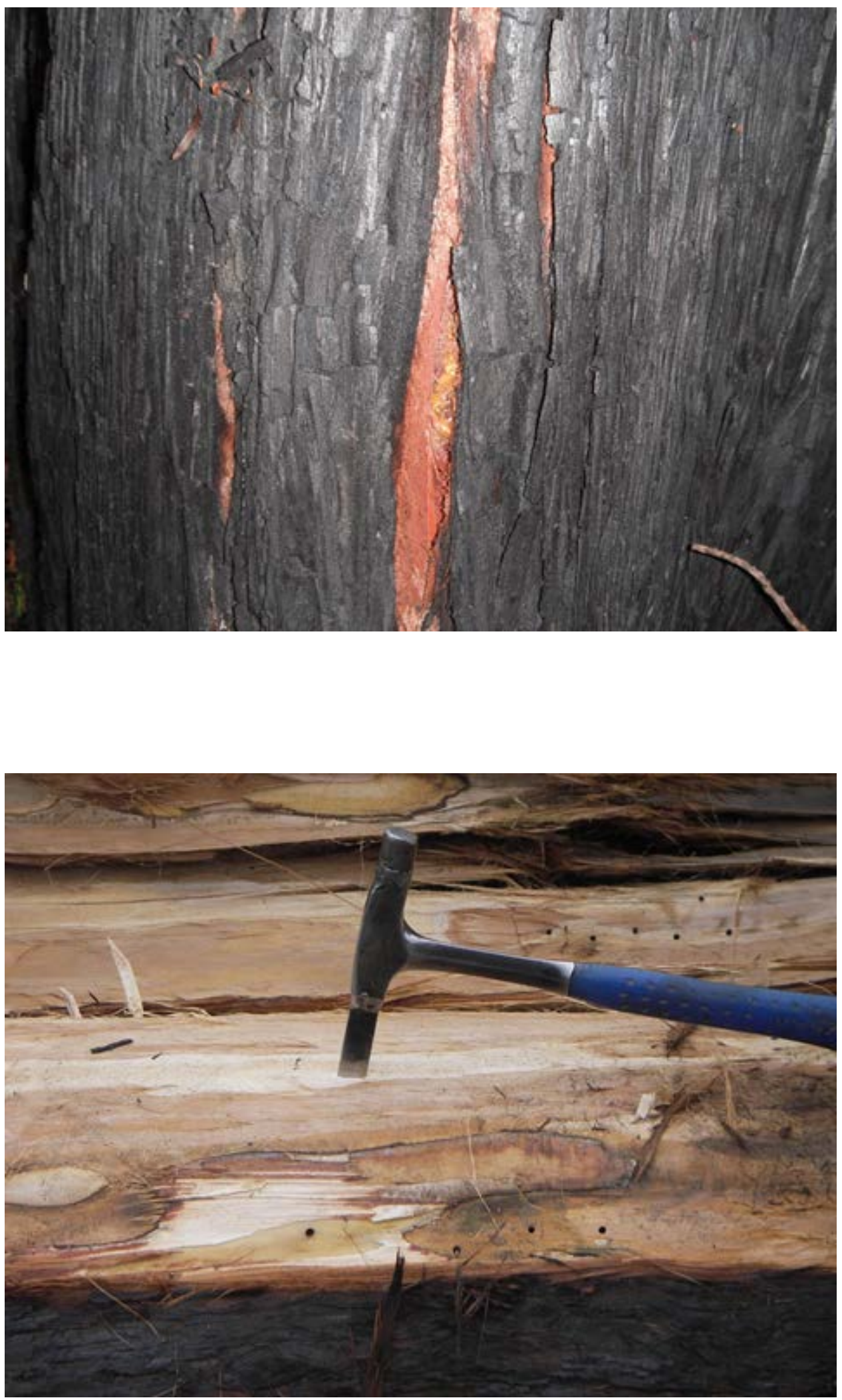

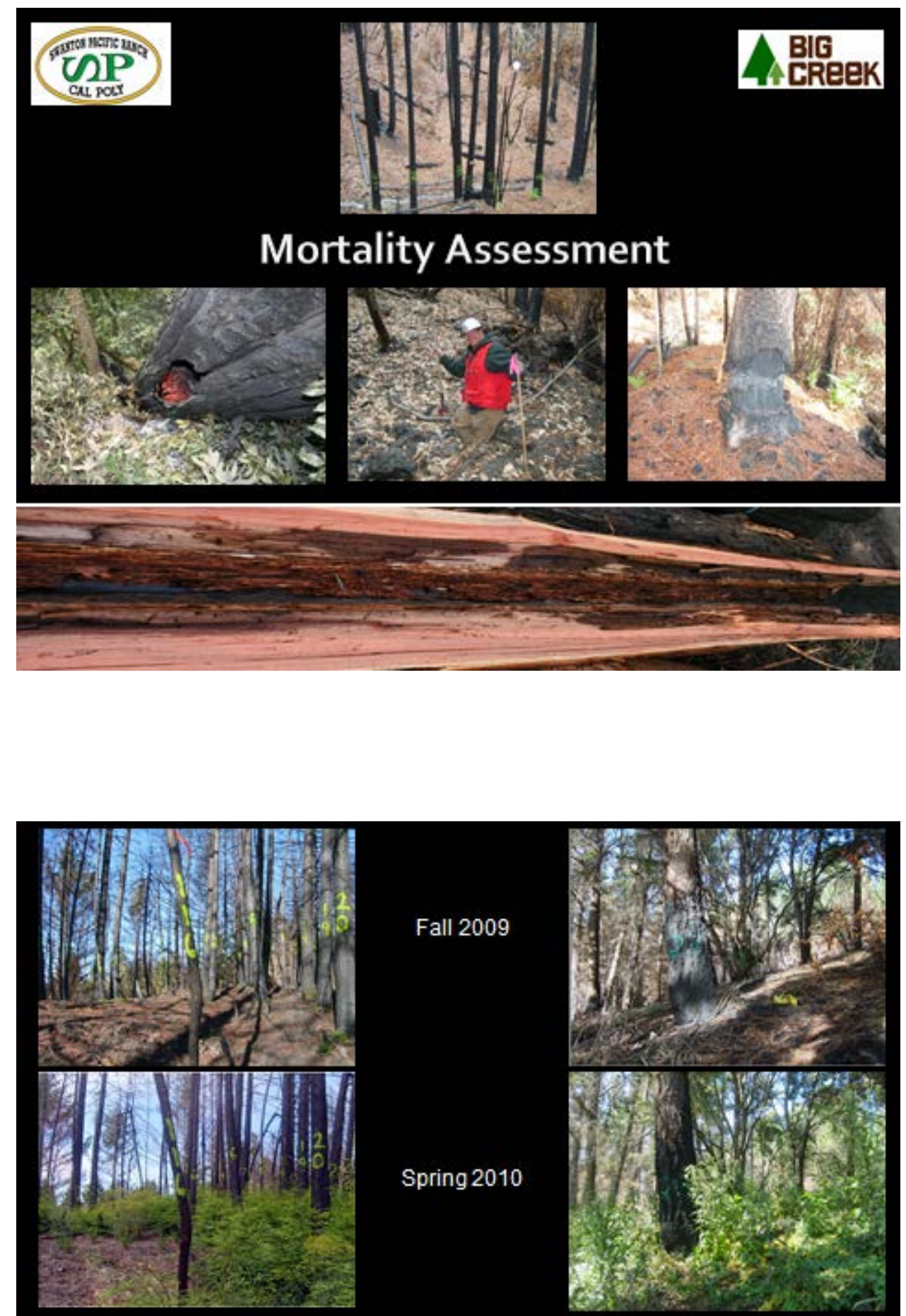

Continuous Forest Inventory utilized for Mortality Assessment

- Systematic random sampling system

$-1 / 5^{\text {th }}$ acre fixed plots

- Percent crown remaining

- Percent crown sprouting

- Basal sprouting Y/N

- Percent root system burned

- Cambium quadrants burned (4 possible)

- Live or die? Y/N

- Plot photos in cardinal direction 

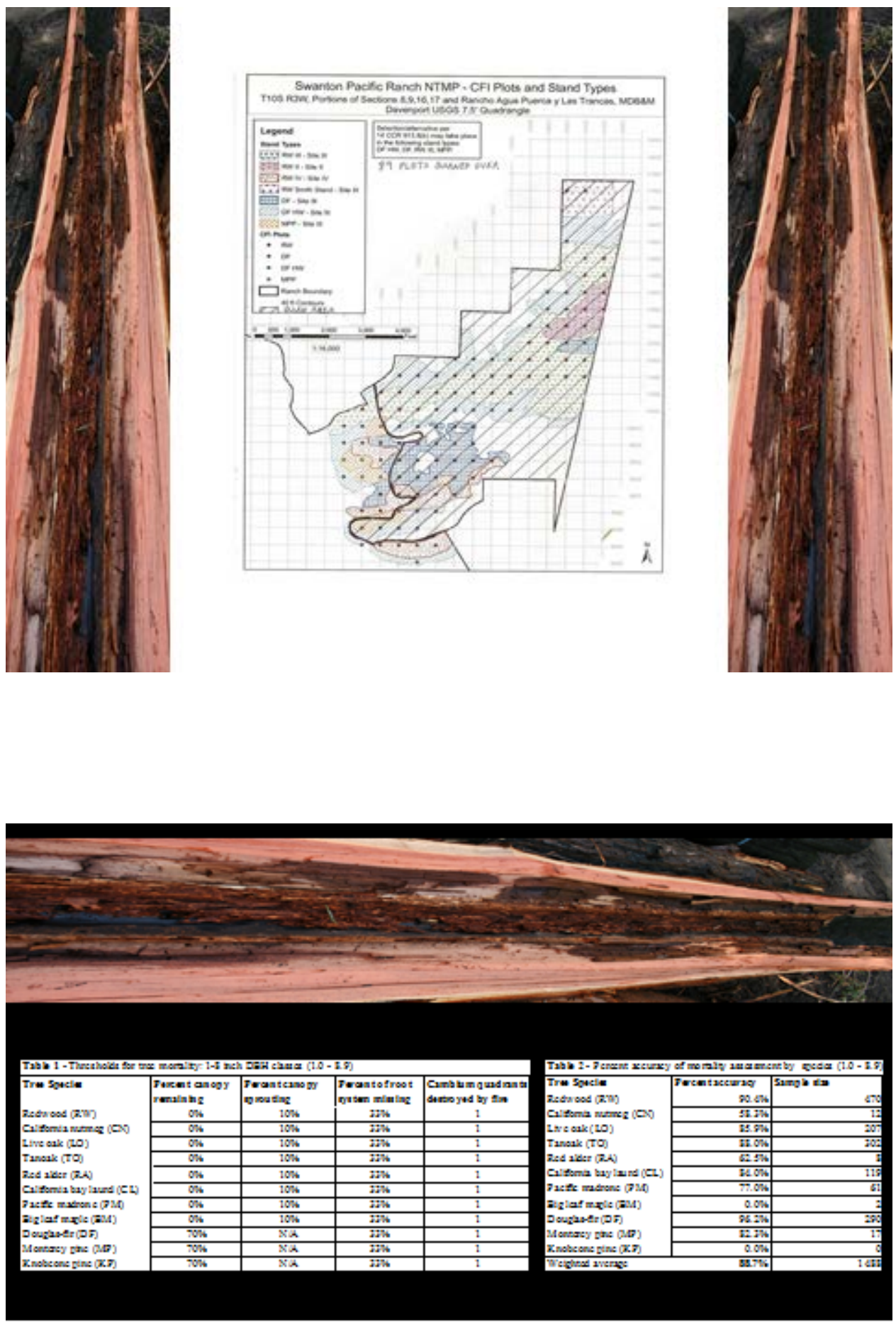

Mortality Assessment Table $1-8^{\prime \prime} \mathrm{DBH}$ and percent accuracy by species 


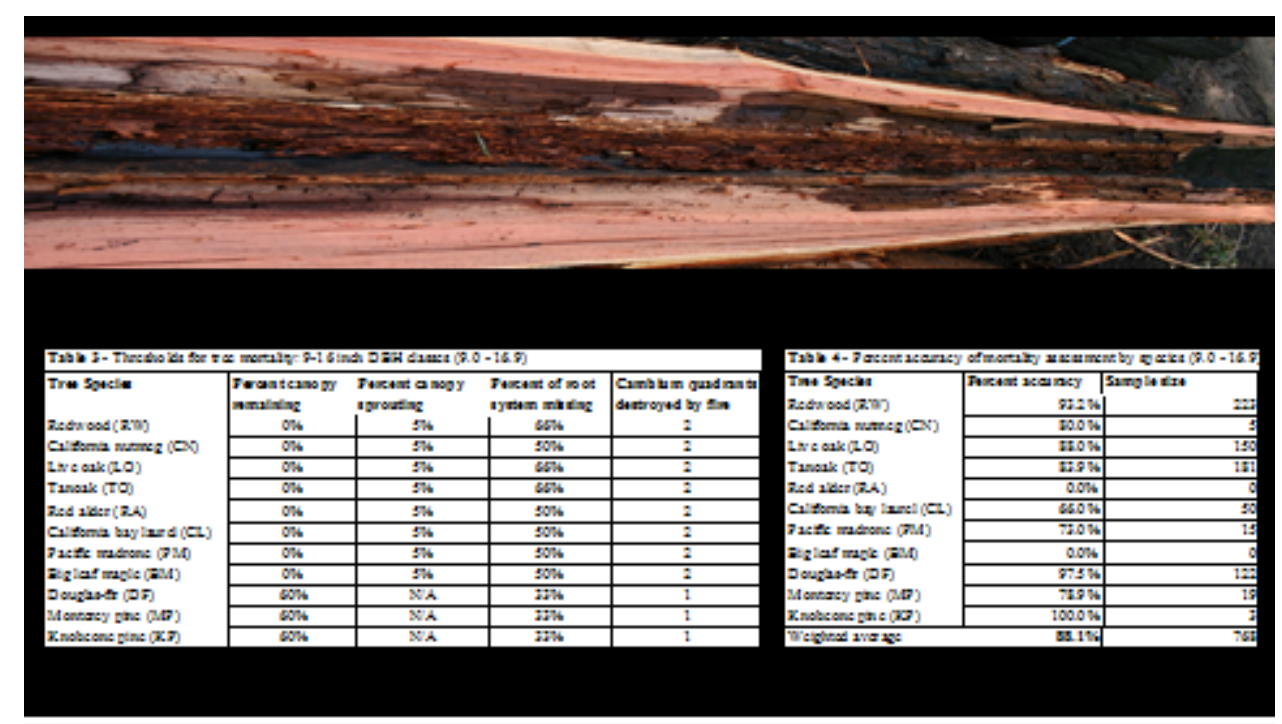

Mortality Assessment Table 9-16" DBH percent accuracy by species

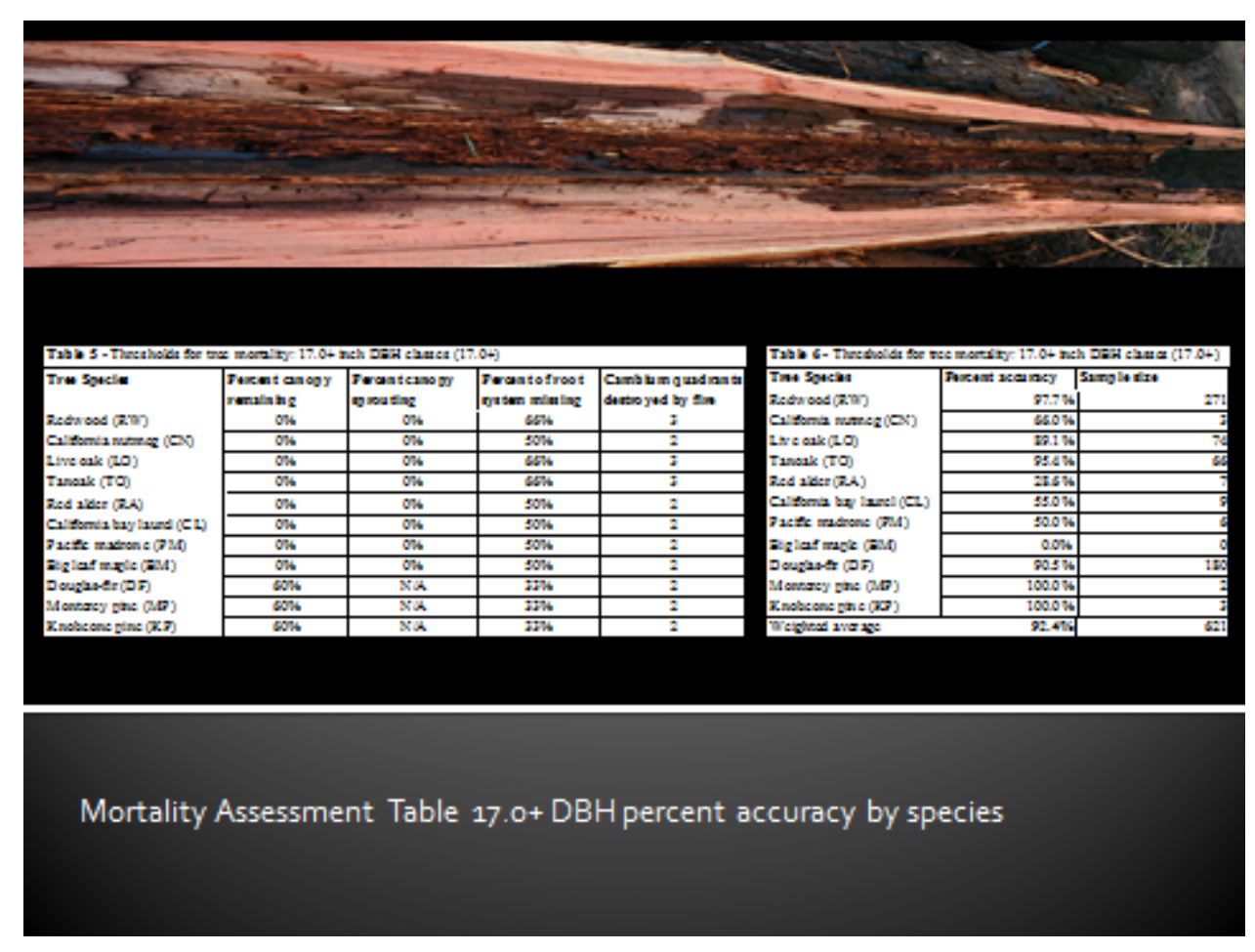


- 2877 samples with an overall weighted accuracy of $89.3 \%$

- Mortality assessment tables faltered on California nutmeg, Red Alder, California bay, Pacific madrone, and Big leaf maple in the medium (9-16) and large (17.0+)

-These trees did not withstand as much cambial damage as we initially specified in the mortality assessment

- Postedvery strong results for Redwood, Tanoak, Live oak, Douglas-fir, Monterey pine, and Knobcone pine to date

- Accuracy would likely be increased with additional information on scorch height and bark thickness

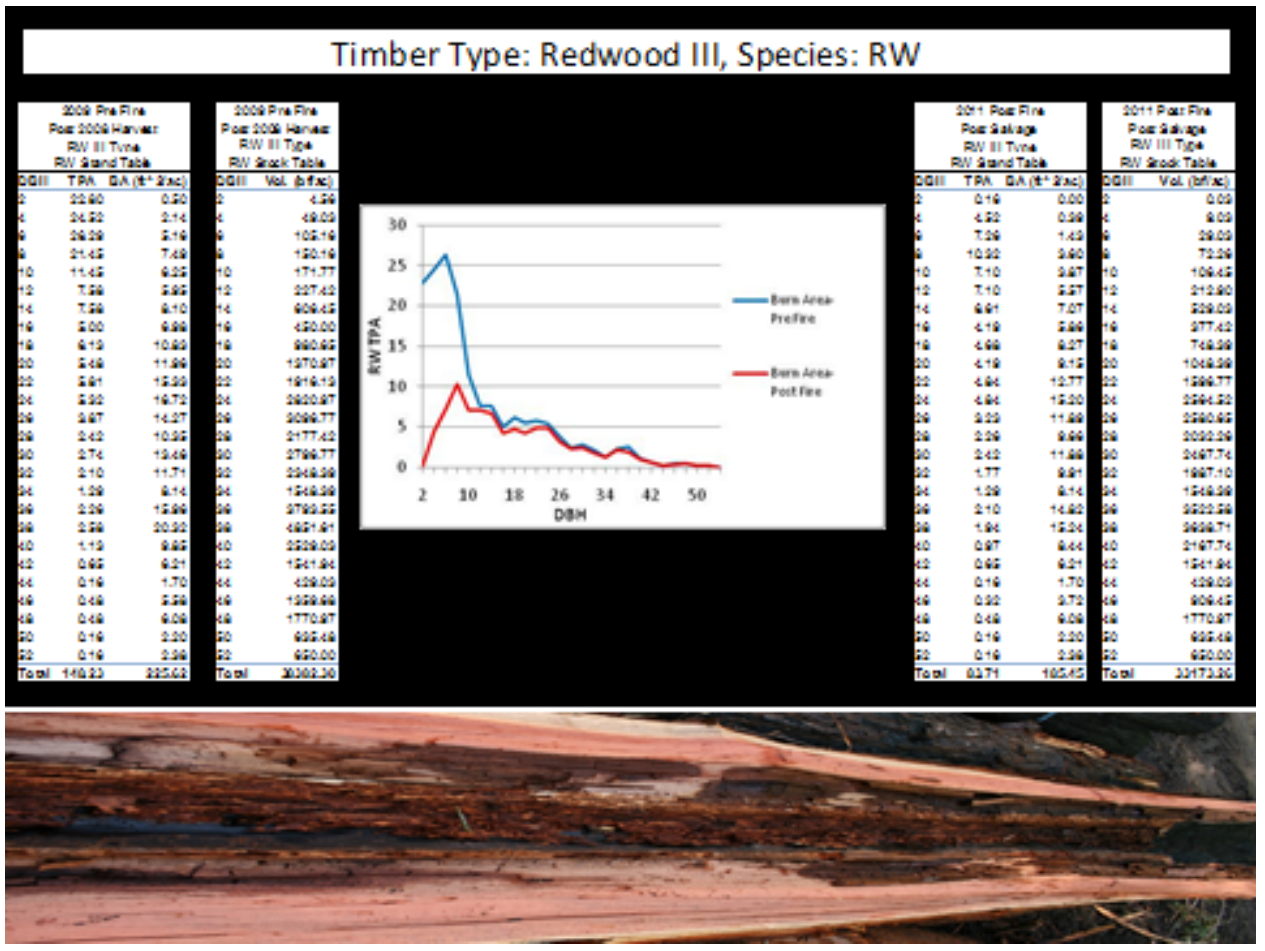



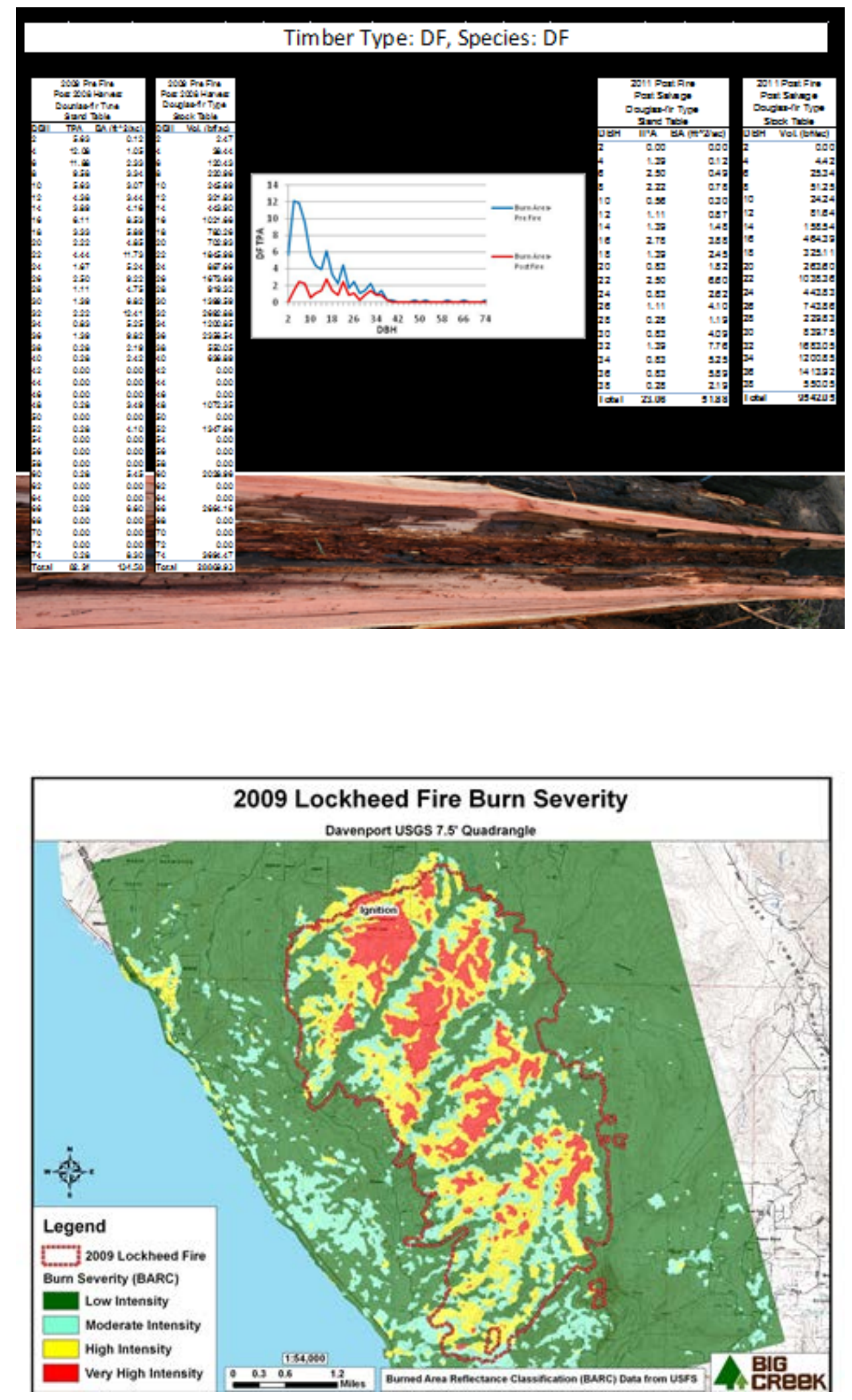


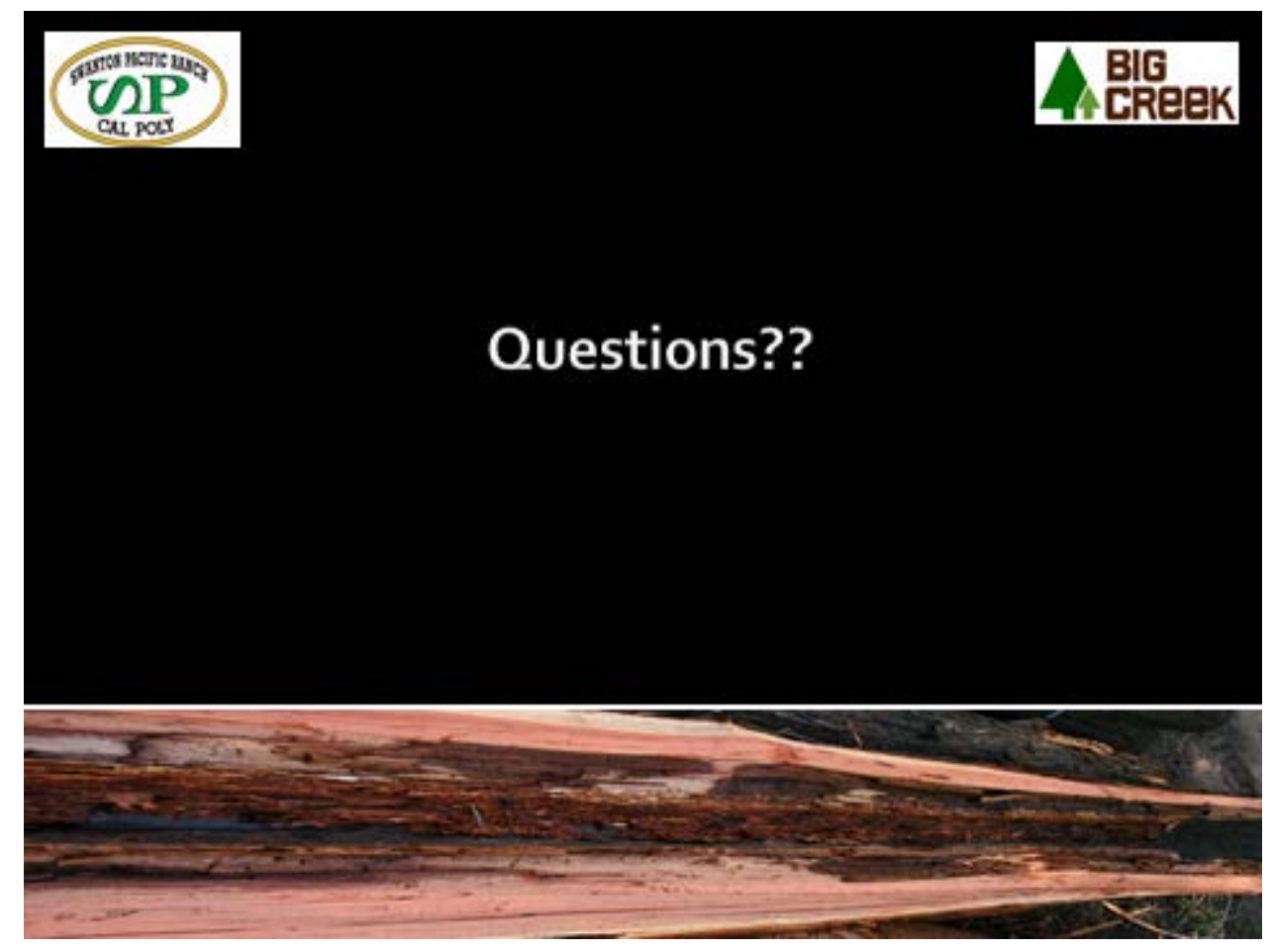


Appendix C

Power Point Presentation of Thesis Defense for "Mortality assessment of redwood and mixed conifer forest types in Santa Cruz County following wildfire”
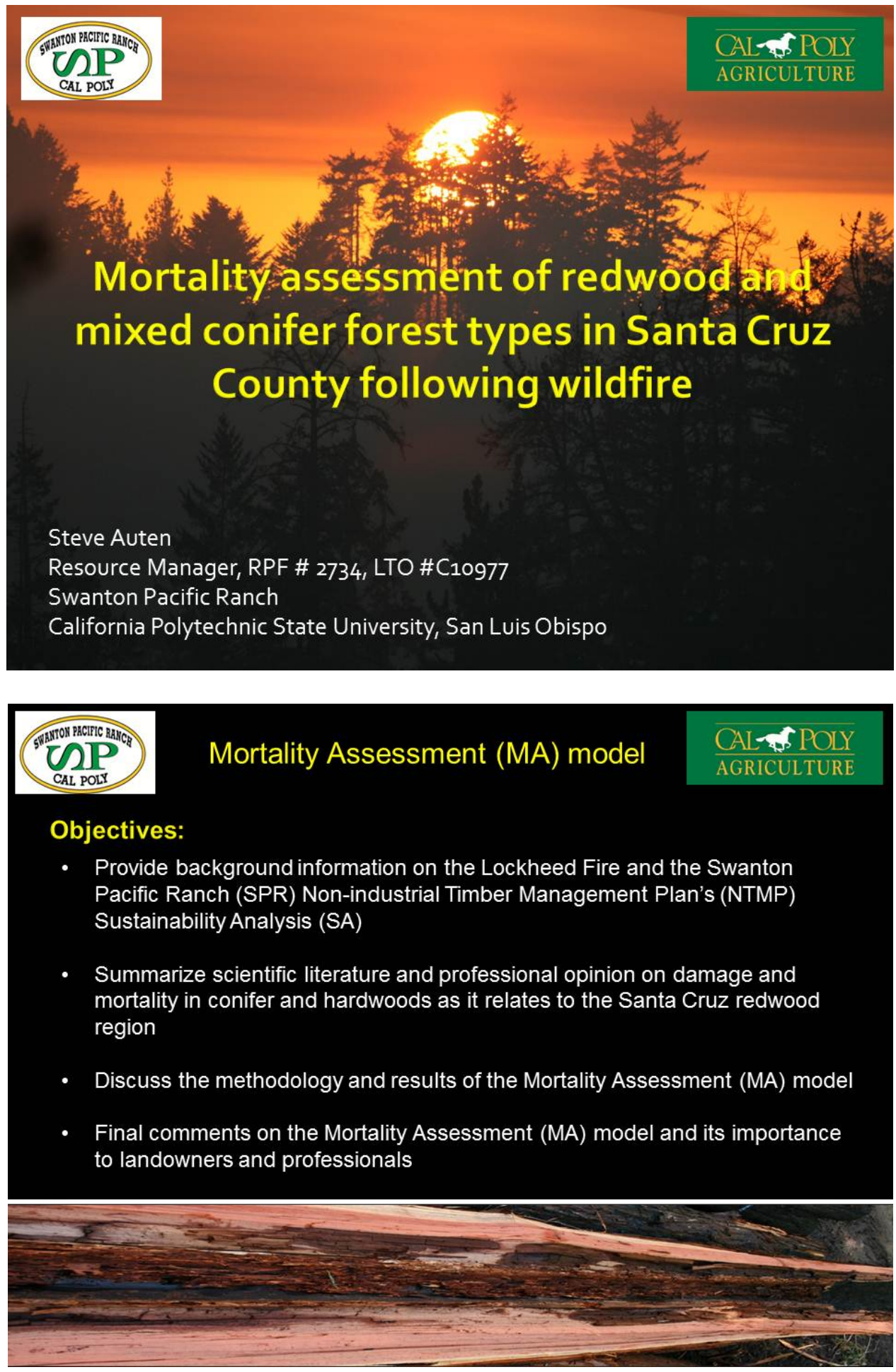

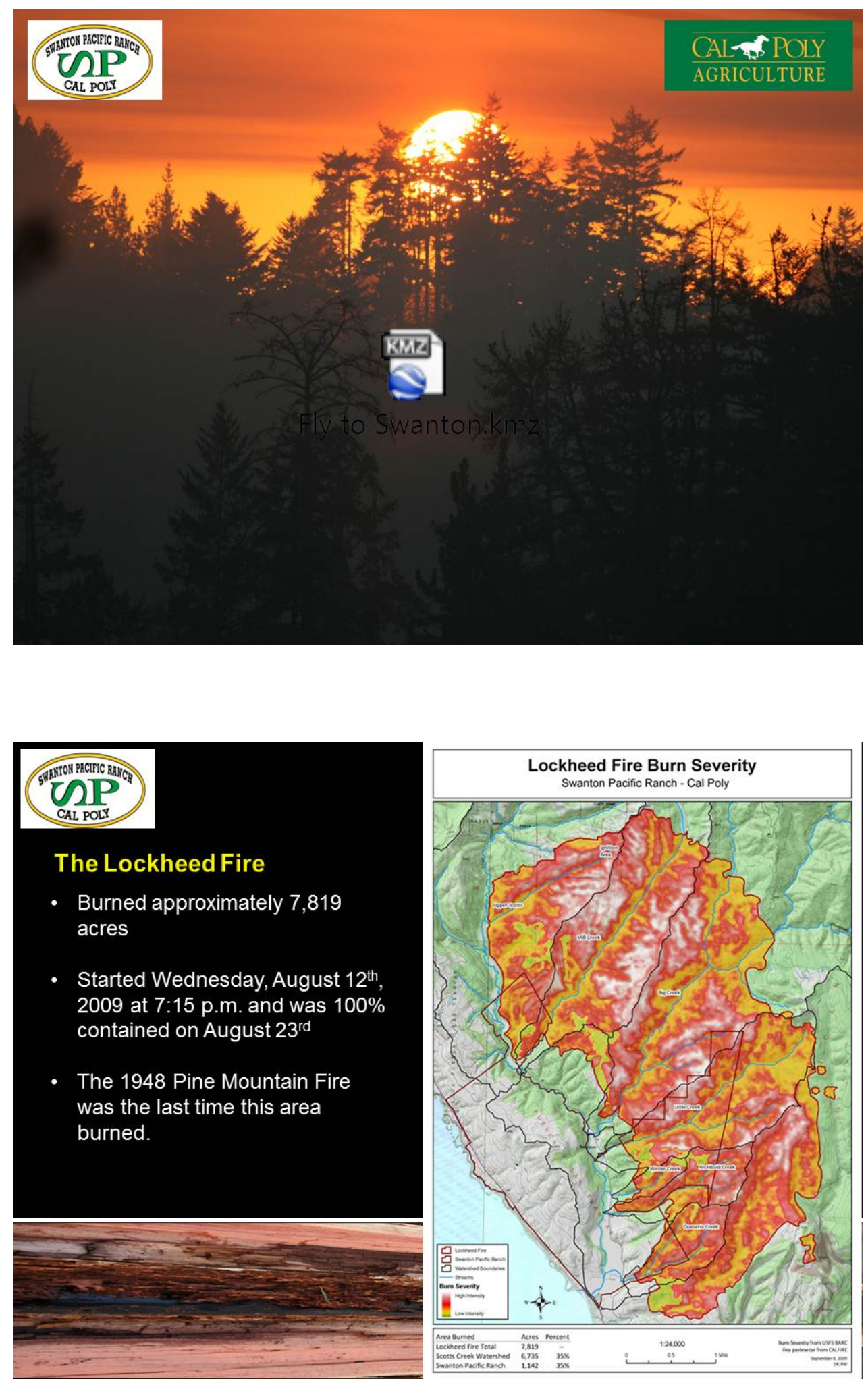

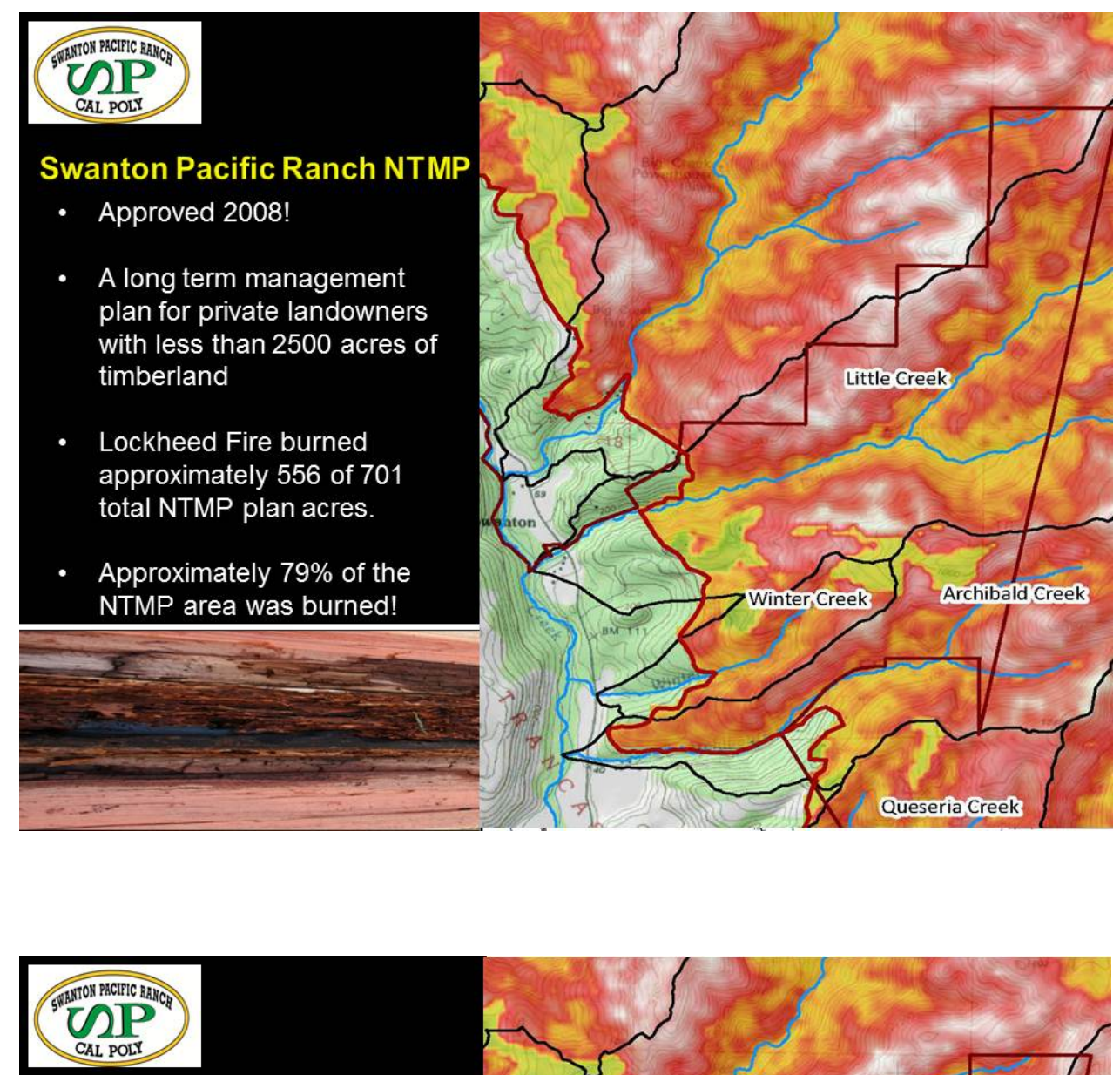

Sustainability Analysis

- Required in a NTMP

- The purpose is to prove that harvesting will be balanced with growth over time.

- Requires a forest inventory

- Many younger trees that support growth projections in the SA were significantly reduced due to the 2009 Lockheed Fire

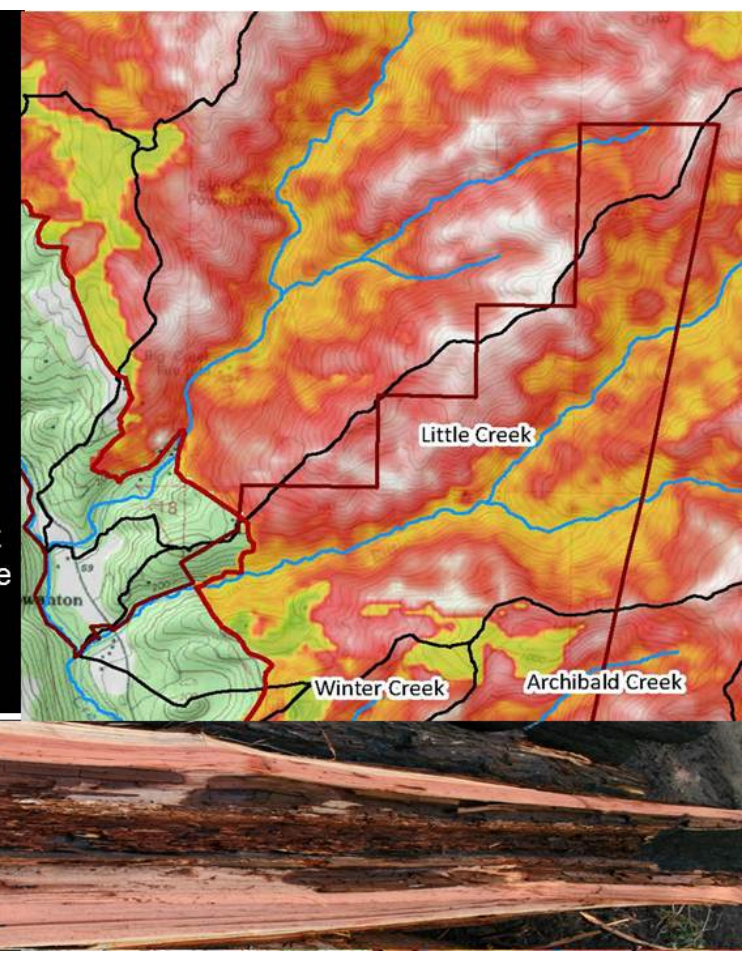




\section{Mortality Assessment (MA) model}

\section{Problems:}

- Cal Fire informed SPR that the sustainability analysis did not represent current conditions following the Lockheed Fire.

- A new SA would have to be re-submitted reflecting post-fire conditions before harvesting operations under the NTMP could continue.

- Salvage helicopter harvesting in managed areas was to begin in February 2010 , just months after the fire began.

- NTMP harvesting in the South Fork of Little Creek was to proceed the following February in 2011.

- Very little scientific research was available to assist SPR in determining tree mortality.

- SPR was the first NTMP to burn in California.

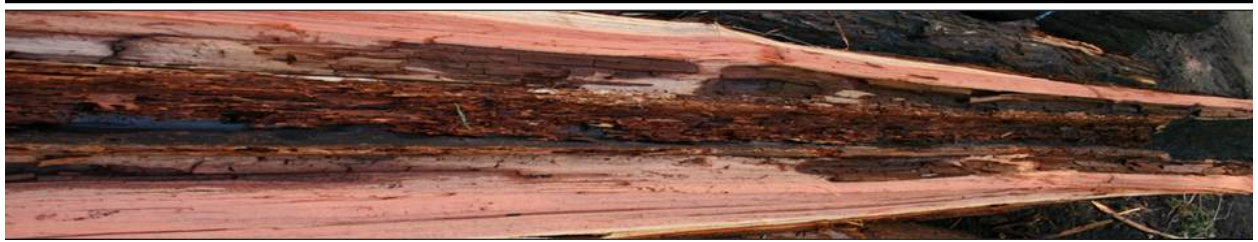

\section{(imis}

\section{Mortality Assessment (MA) model}

CAL \& POLY AGRICULTURE

\section{Unique research opportunities:}

- SPR had recent pre-fire data on over 4,000 trees from the CFI system for both conifers and hardwoods.

- A fire recovery budget had been created for SPR by Cal Poly.

- Adjacent property affected by fire was owned by Big Creek Lumber Company

- Recent fire events on lands of Redwood Empire

- Very supportive local forestry community

- Tremendous opportunity for research that builds on the research infrastructure put in place years ago

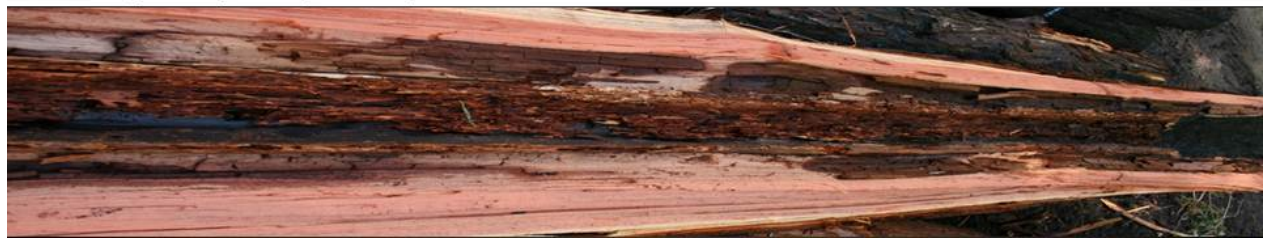



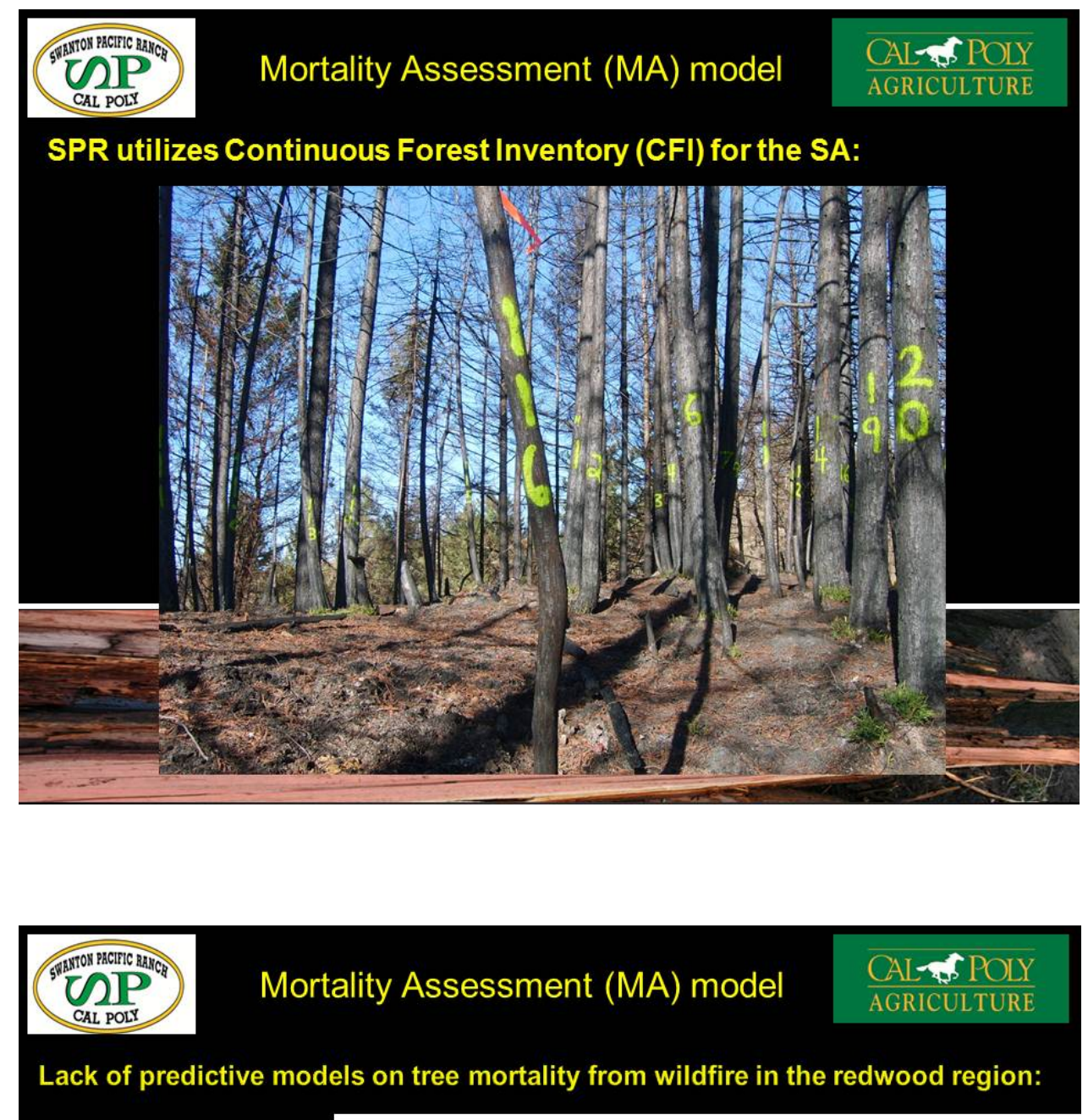

Only one study using prescribed burning has been published in the redwood region!

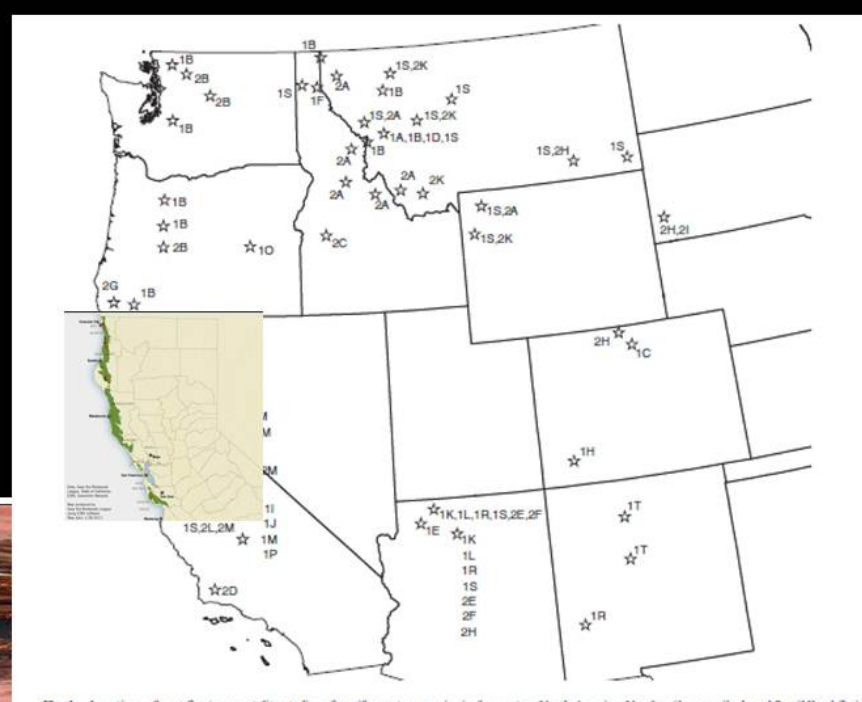

He 1. Locations of post fire tree mortality stadies of conifo 
Most other scientific research on tree mortality in California and wildfire focused on Sierran forest types:

- Crown injury

- Stem injury

- Only indirect discussion on root systems

- Bark thickness

- Fuels

- Season of burn

- Insect and pathogens

Based on Woolley et.al 2012, there have been 32 studies using logistic regression models to predict post-fire tree mortality of western North American conifers and only one publication for redwood. Of these studies, only 8 publications have had more than 1000 trees.

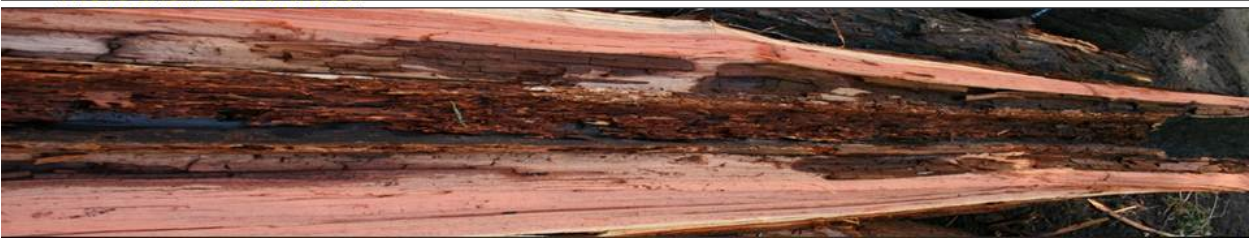

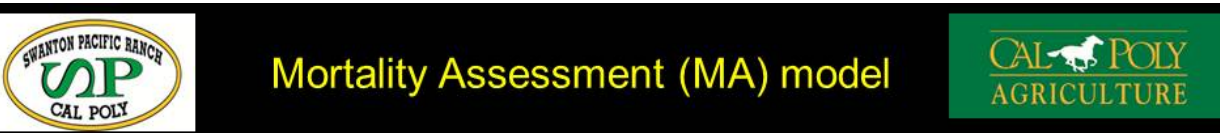

\section{Question:}

Given the lack of robust research on fire-based mortality in the redwood region, can a sound predictive model be developed?

\section{Hypothesis:}

Mortality assessment models based on professional opinion and related research can accurately predict the mortality of trees in redwood and mixed conifer forest types in Santa Cruz County immediately following wildfire.

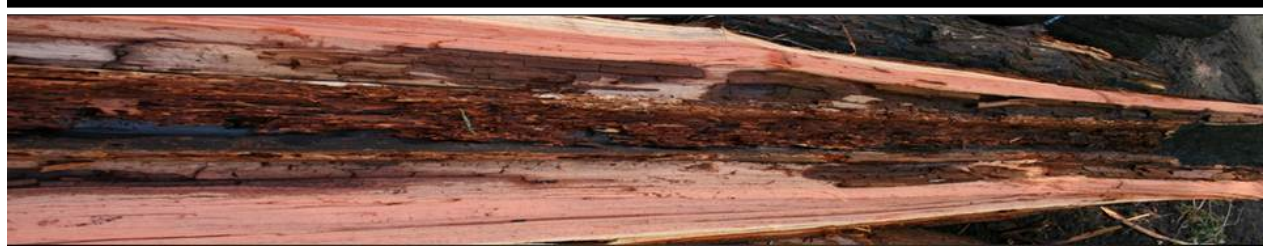




\section{Mortality Assessment (MA) model}

\section{Where do we go from here?}

- Landowners and foresters in the redwood region need a sound method to evaluate burn severity on trees and the resulting likelihood of survival.

- SPR, with the assistance of other local foresters and available literature, created a Mortality Assessment (MA) model that builds upon "criteria for survival marking of fire-scorched timber in California" proposed by Wagener (1961).
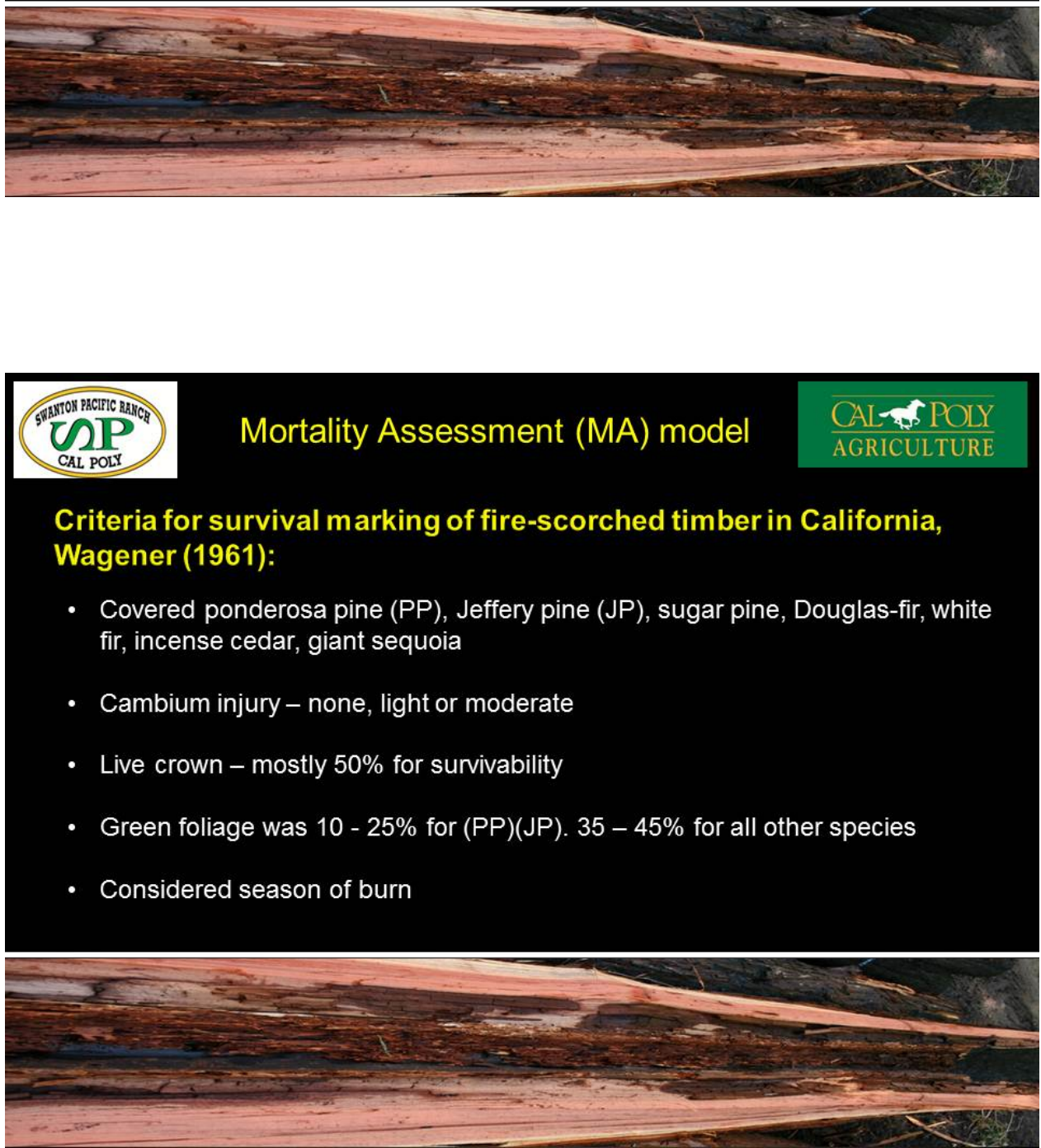
Professional opinion from local foresters on evaluating the effects of burn severity in the redwood region:

- What does a tree need to survive?

- Cambium (C), Roots (R), Leaves or Needles (LN)

- Sprouting tree species survival in the redwood region are completely different than Sierran species.

- Axillary buds

- Roots

- Carbohydrate storage

- Tree damage evaluation techniques

- Sounding the tree to determine cambial death

- Probing around the tree to locate root voids
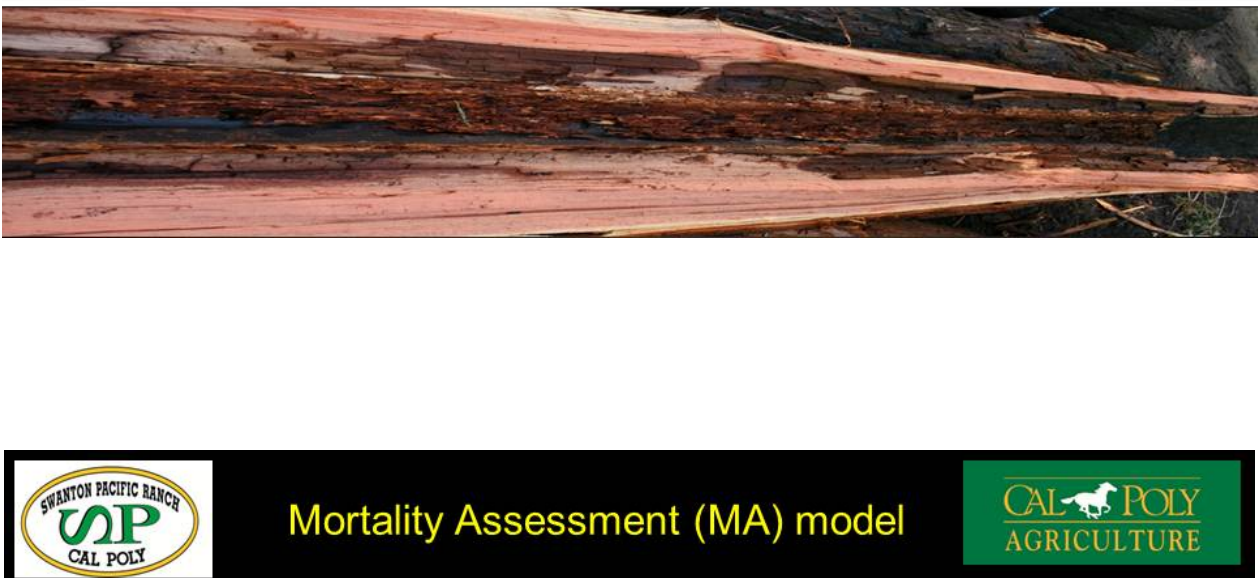

\section{Mortality Assessment (MA) model}

CAL -5 POLY AGRICULTURE

The Mortality Assessment (MA) model focused on determining species, diameter, and evaluating the following characteristics that affect a tree's likelihood of survival following wildfire.

MA model variables:

- Cambium $(\mathrm{C})=$ Cambium Quadrants Destroyed by Fire (CQDF)

- Roots $(R)=$ Percent of Root System Missing (PRSM)

- Leaves and Needles (LN) = Percent Canopy Remaining (PCR)

- Sprouting Species $(\mathrm{LN})=$ Percent Canopy Sprouting (PCS)

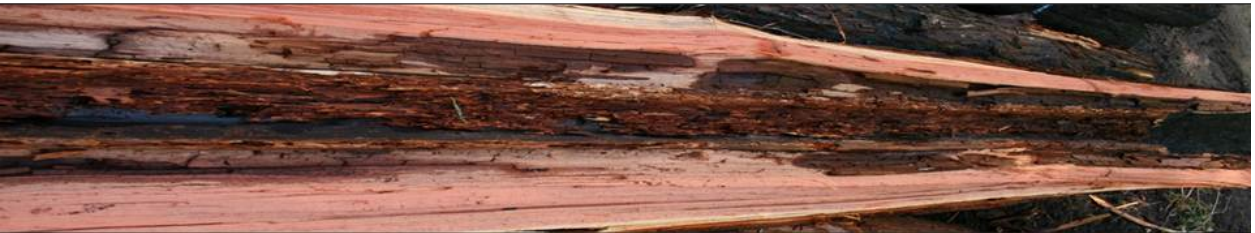



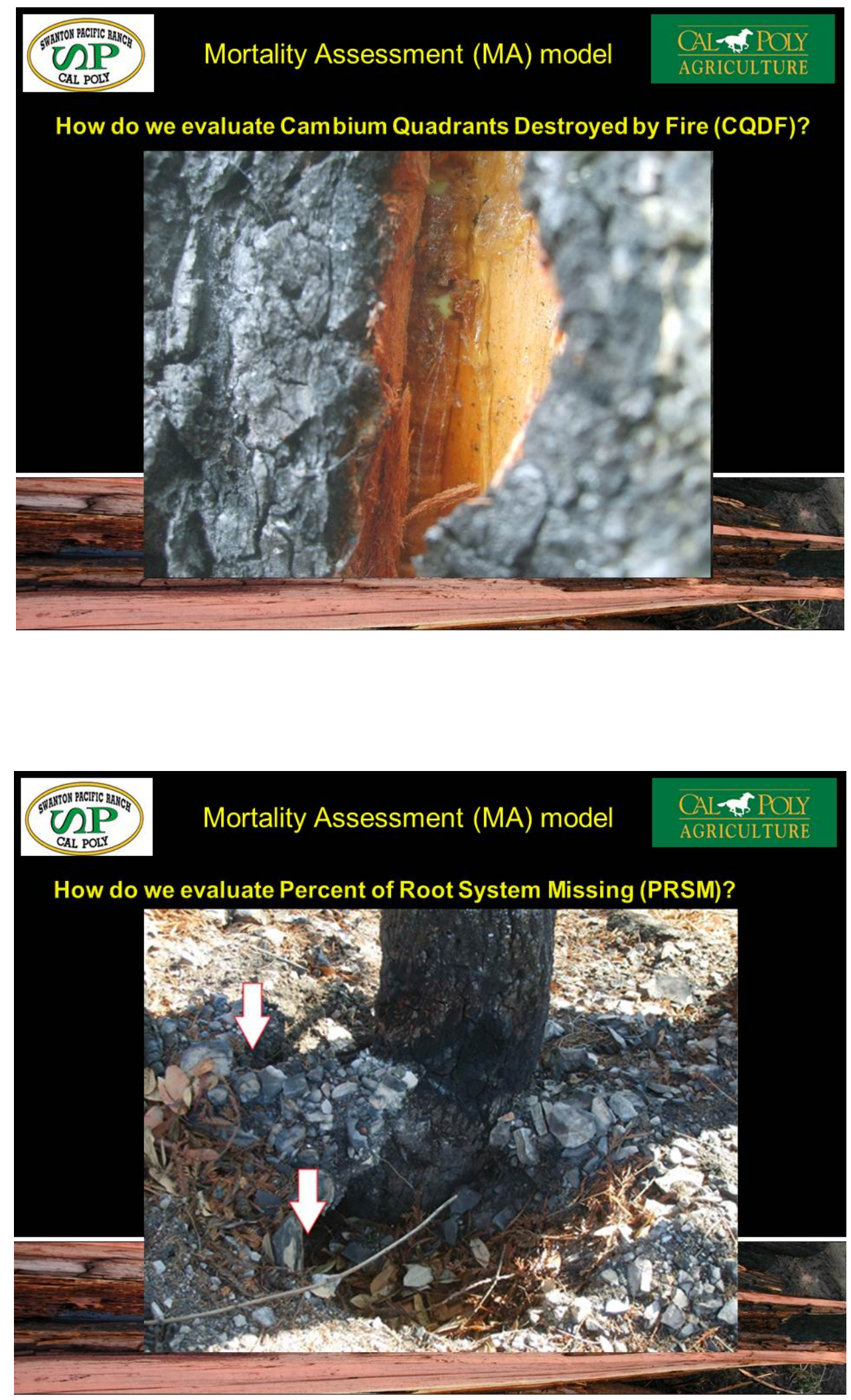

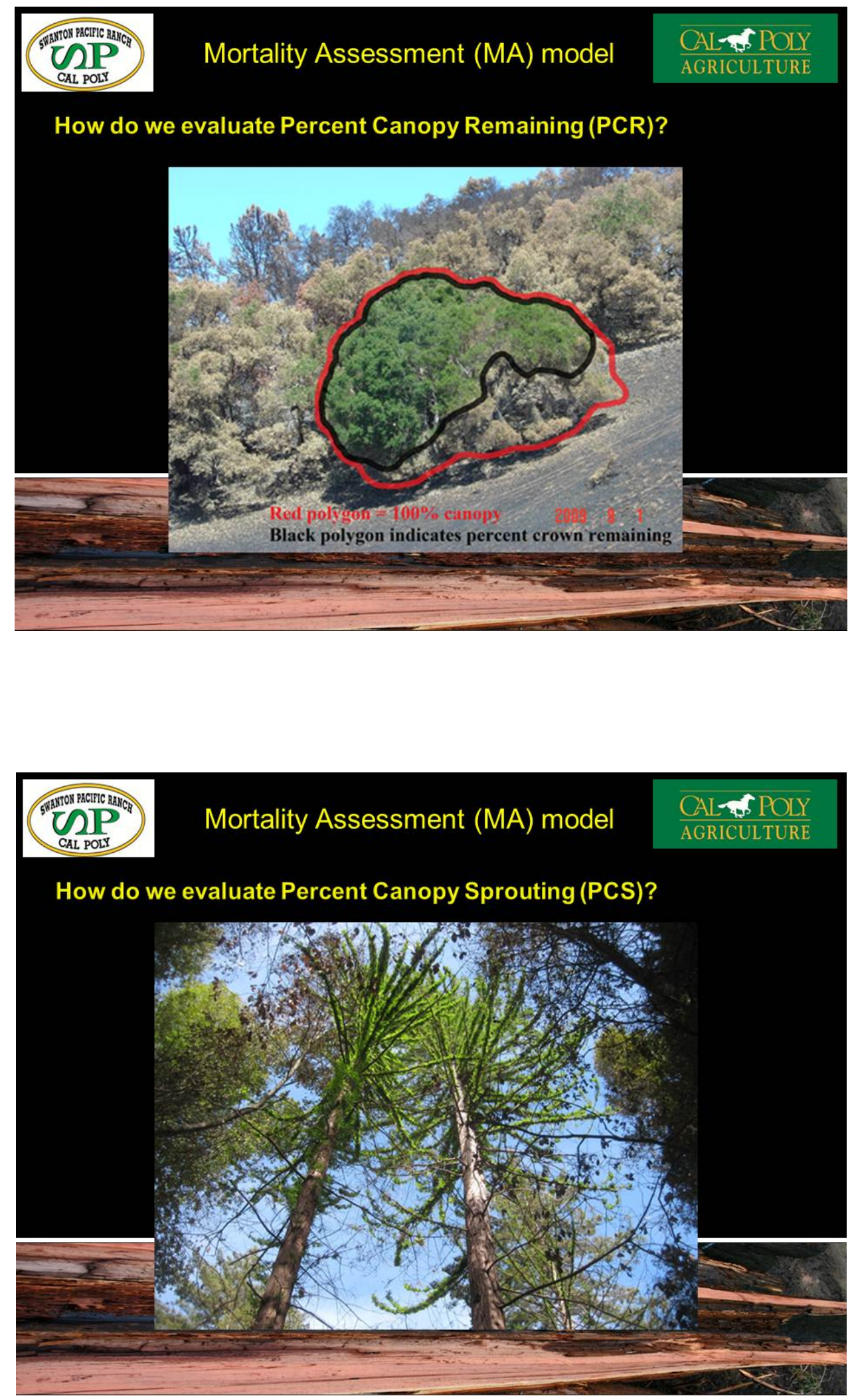


\section{Mortality Assessment (MA) model summary for the following species:}

Redwood (RW), California nutmeg (CN), live oak (LO), tanoak (TO), red alder (RA), California bay (CB), Pacific madrone (PM), big leaf maple (BLM), Douglas-fir (DF), Monterey pine (MP), knobcone pine (KP) $-n=2877$

$1.0-8.9$ inch DBH Class

$9.0-16.9$ inch DBH Class

$>17.0$ inch DBH Class
- $\mathrm{CQDF}=1$

- $\operatorname{PRSM}=33 \%$

- $\mathrm{PCR}=0 \%, 70 \%$ for $\mathrm{DF}, \mathrm{MP}, \mathrm{KP}$

- $\mathrm{PCS}=10 \%, \mathrm{NA}$ for DF, MP, KP

- $\mathrm{CQDF}=2,1$ for $\mathrm{DF}, \mathrm{MP}, \mathrm{KP}$

- $\mathrm{PRSM}=50-66 \%, 33 \%$ for $\mathrm{DF}, \mathrm{MP}, \mathrm{KP}$

- $\mathrm{PCR}=0 \%, 60 \%$ for $\mathrm{DF}, \mathrm{MP}, \mathrm{KP}$

- $\mathrm{PCS}=5 \%, \mathrm{NA}$ for DF, MP, KP

- $\mathrm{CQDF}=2-3,2$ for DF, MP, KP

- $\mathrm{PRSM}=50-66 \%, 33 \%$ for DF, MP, KP

- $\mathrm{PCR}=0 \%, 60 \%$ for DF, MP, KP

- $\mathrm{PCS}=0 \%, \mathrm{NA}$ for $\mathrm{DF}, \mathrm{MP}, \mathrm{KP}$

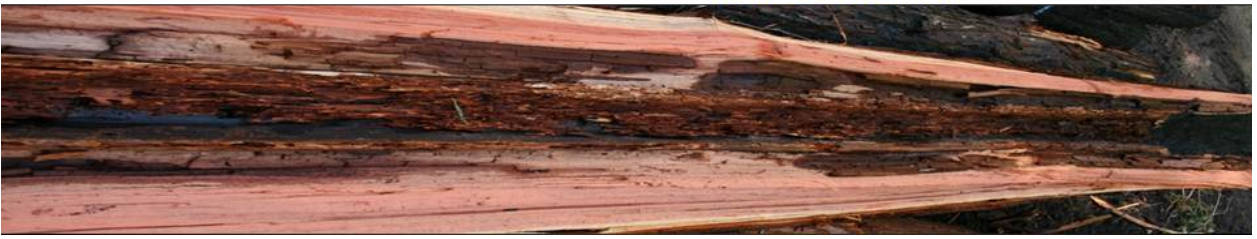

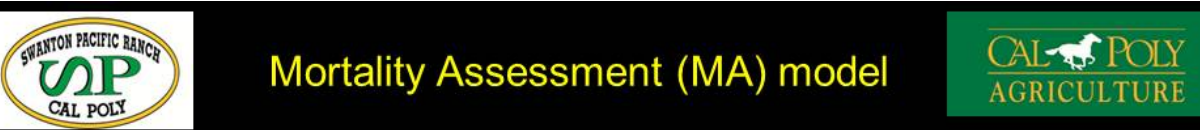

General results with 2 re-evaluation periods (2010 and 2011):

- Overall $89.3 \%$ accuracy for all species and DBH classes

- $88.7 \%$ accuracy for all species in the $1-8$ inch DBH Class (1.0"-8.9")

- $88.1 \%$ accuracy for all species in the $9-16$ inch DBH Class $\left(9.0^{\prime \prime}-16.9^{\prime \prime}\right)$

- $92.4 \%$ accuracy for all species in the $>17$ inch DBH Class $\left(>17.0^{\prime \prime}\right)$

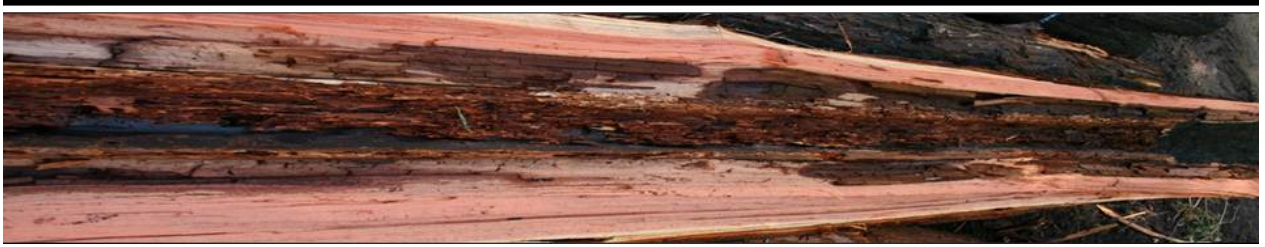




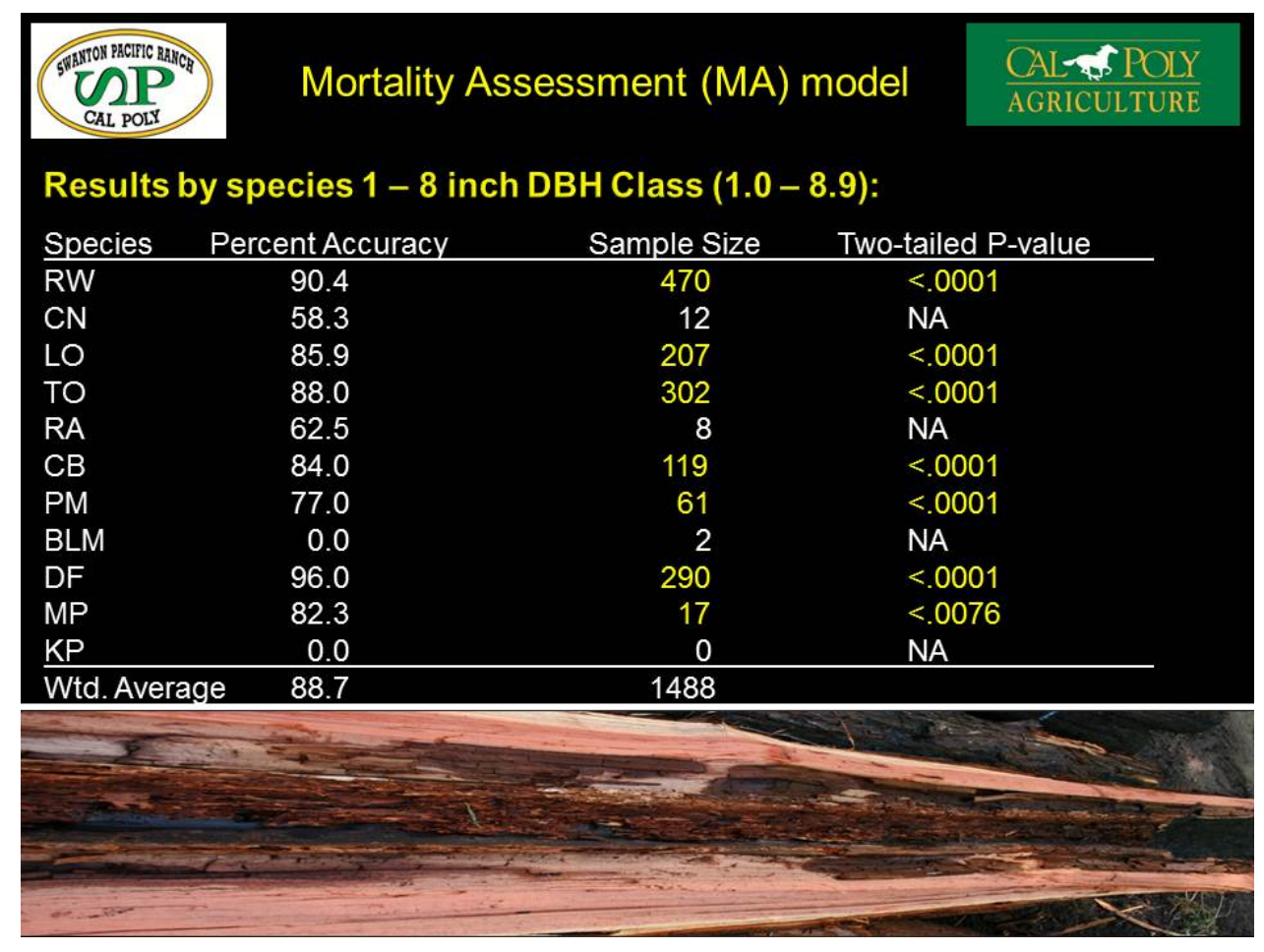

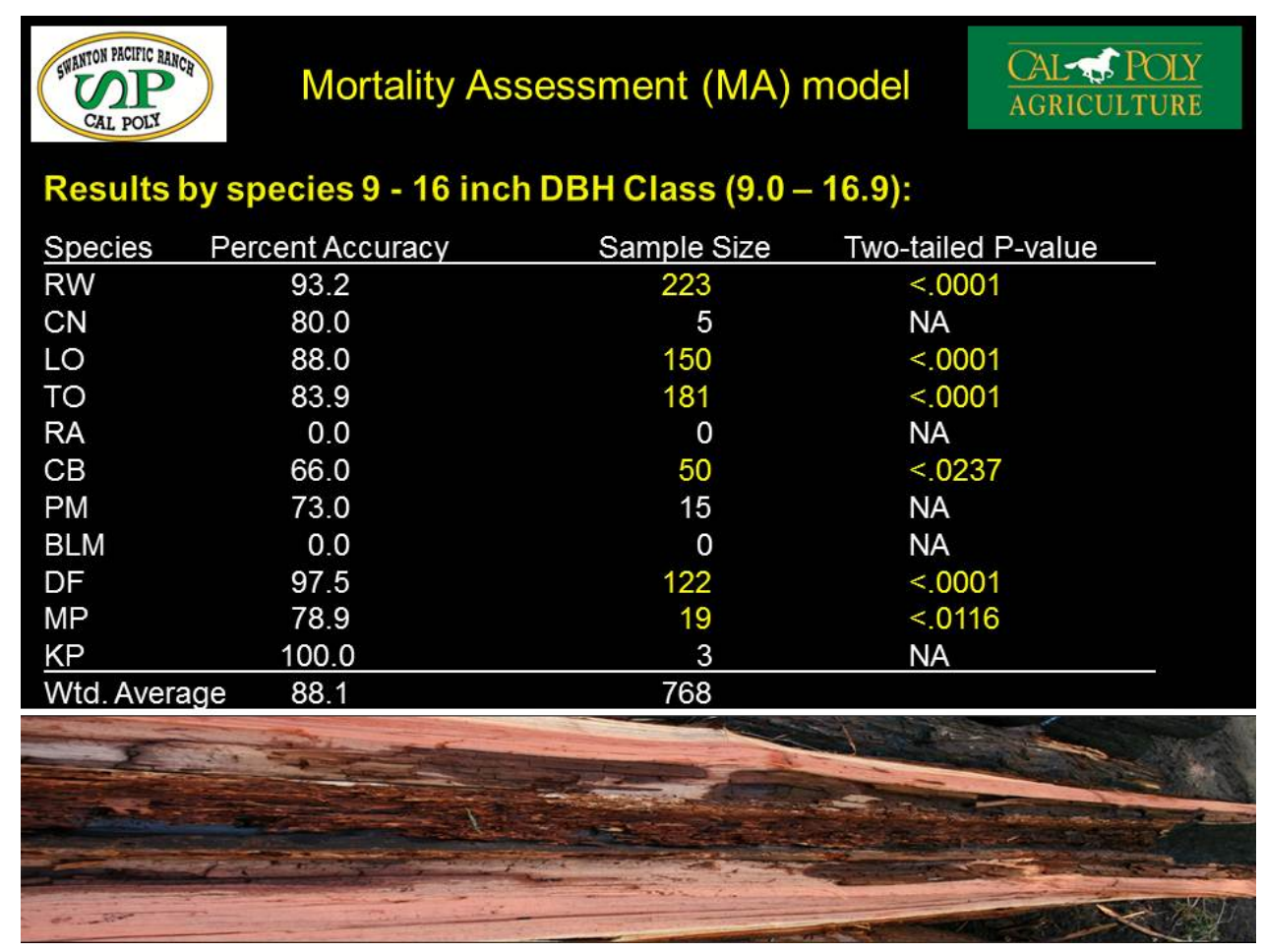




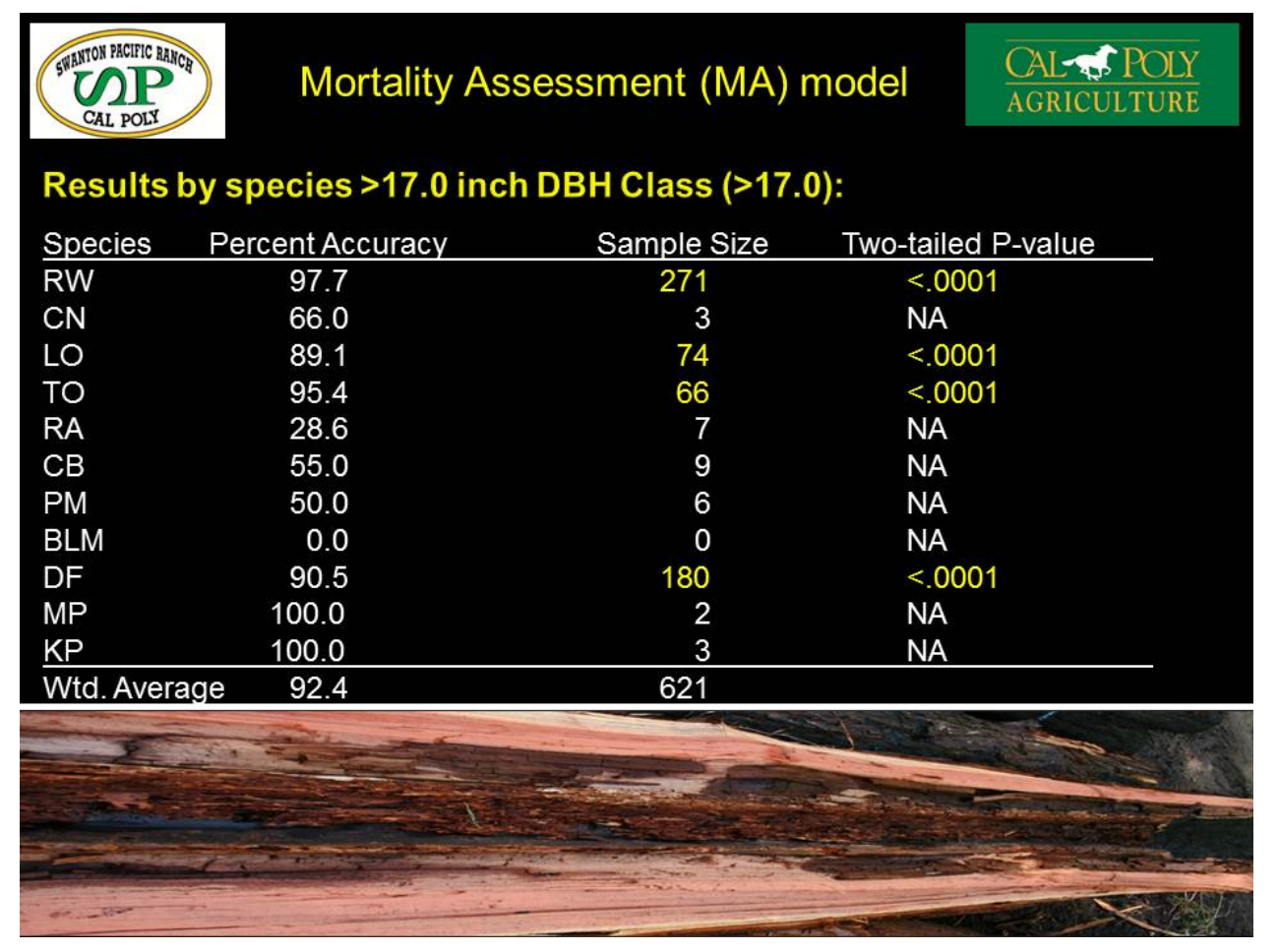

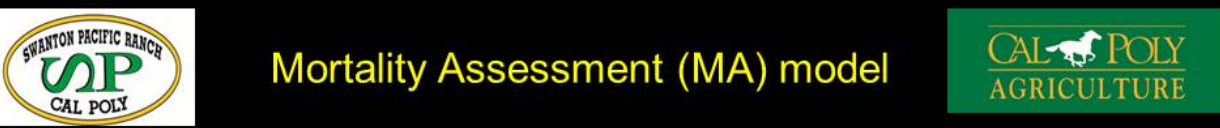

Discussion of results:

- The MA model was very accurate for redwood, live oak, tanoak, and Douglas-fir in all DBH classes.

- Also accurate were California bay 1-8 inch DBH class, Pacific madrone 1-8 inch $\mathrm{DBH}$ class, and Monterey pine 1-8 and 9-16.9 inch DBH class.

- All other species and DBH classes suffered pre-dominantly from lack of sample size.

- During field re-evaluations it was observed that some adjustments could be made to the MA model to increase accuracy.

- Increase PCR and PCS for small to medium diameter species

- Decrease CQDF for small and medium diameter species

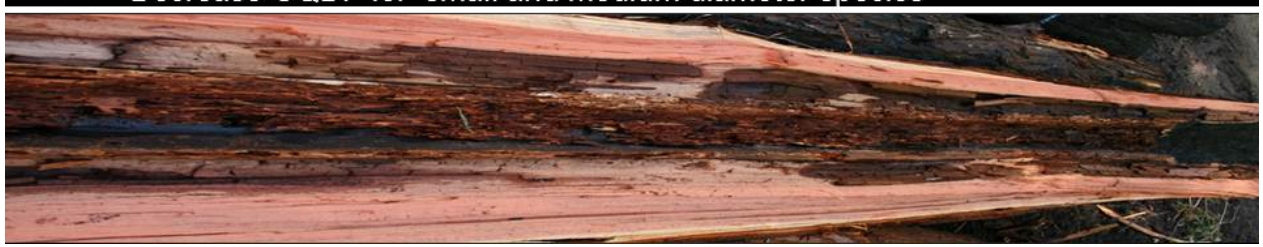




\section{Mortality Assessment (MA) model}

\section{Admissions:}

- The MA model was not intended to be a thesis or publication.

- Values for the variables in the MA model (PCR, PCS, PRSM, CQDF) were not successfully recorded.

- Each tree was evaluated, qualitatively, around the MA model, but if the tree met all of the thresholds by DBH category it was considered dead.

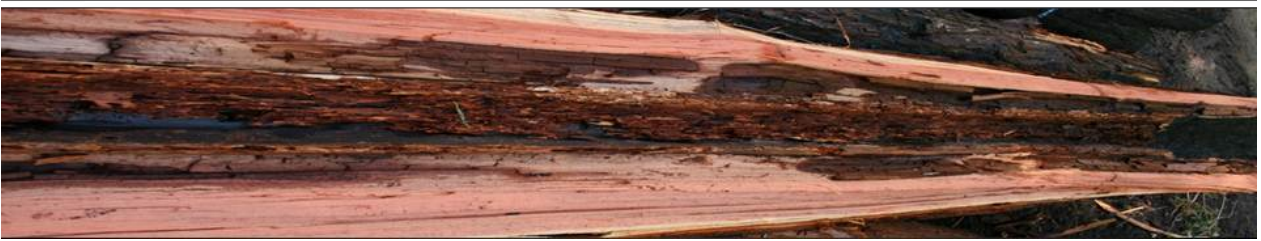

\section{Mortality Assessment (MA) model $\frac{\overline{\text { CAL }} \text { AGS POLY }}{\text { AGRICULTURE }}$}

Preliminary results with 3 re-evaluation periods $(2010,2011$, and 2012):

- Overall $87.9 \%$ accuracy for all species and DBH classes (dropped $1.4 \%$ from $89.3 \%$ in 2011)

- $\mathbf{8 8 . 0} \%$ accuracy for all species in the $1-8$ inch DBH Class (1.0"-8.9")

- $\mathbf{8 5 . 7} \%$ accuracy for all species in the $9-16$ inch DBH Class $\left(9.0^{\prime \prime}-16.9^{\prime \prime}\right)$

- $90.5 \%$ accuracy for all species in the $>17$ inch DBH Class $\left(>17.0^{\prime \prime}\right)$

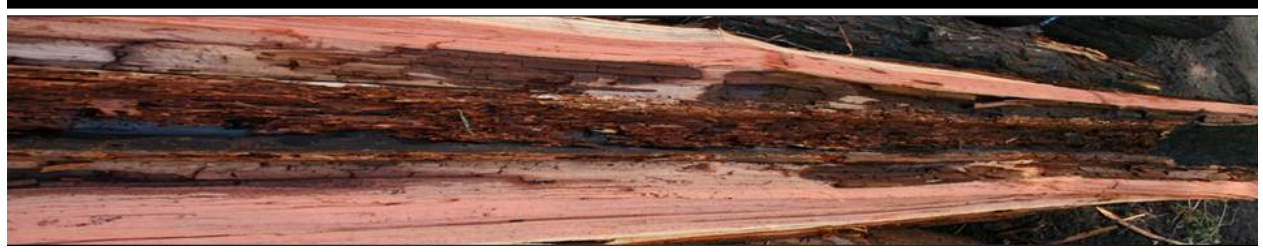



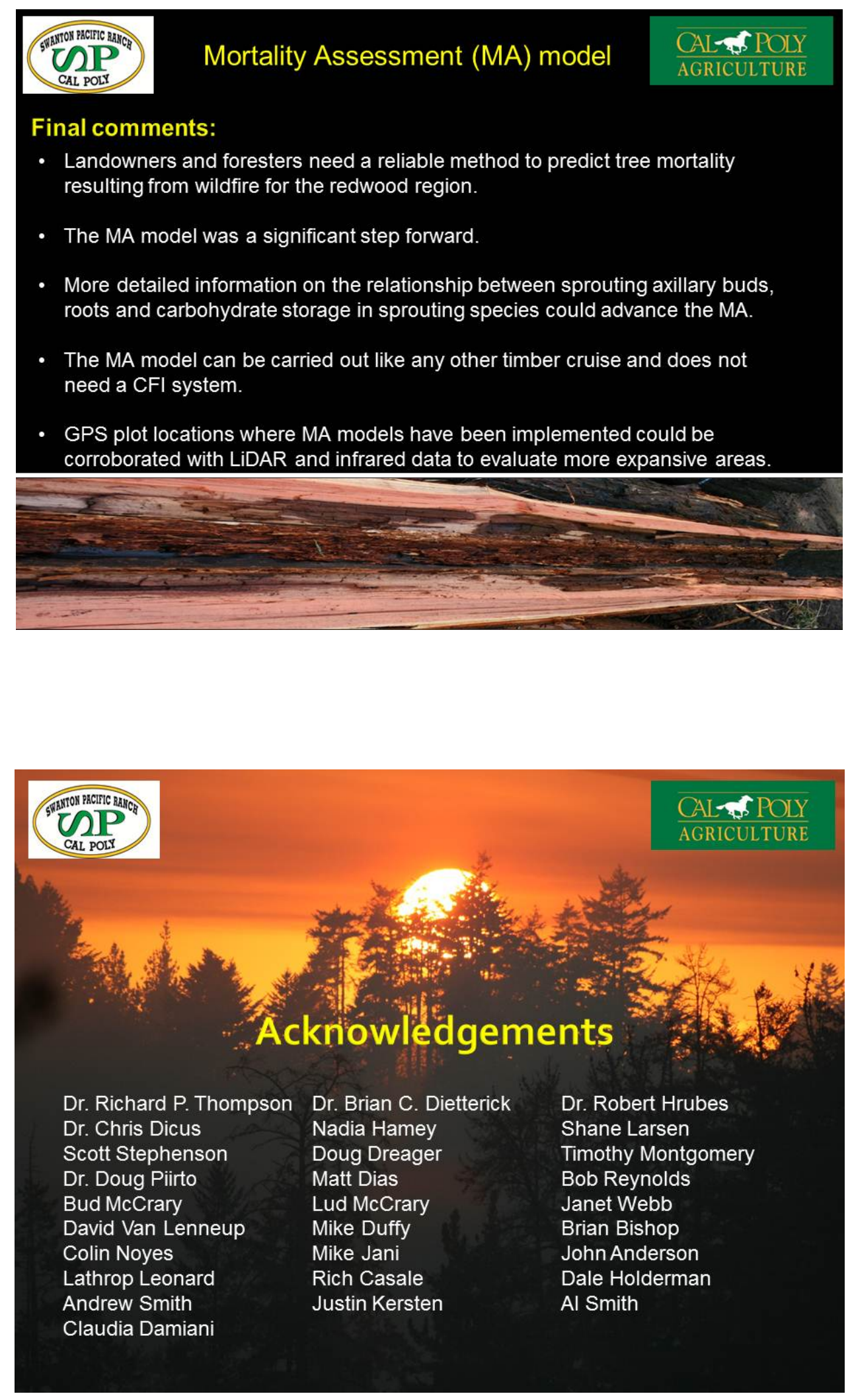


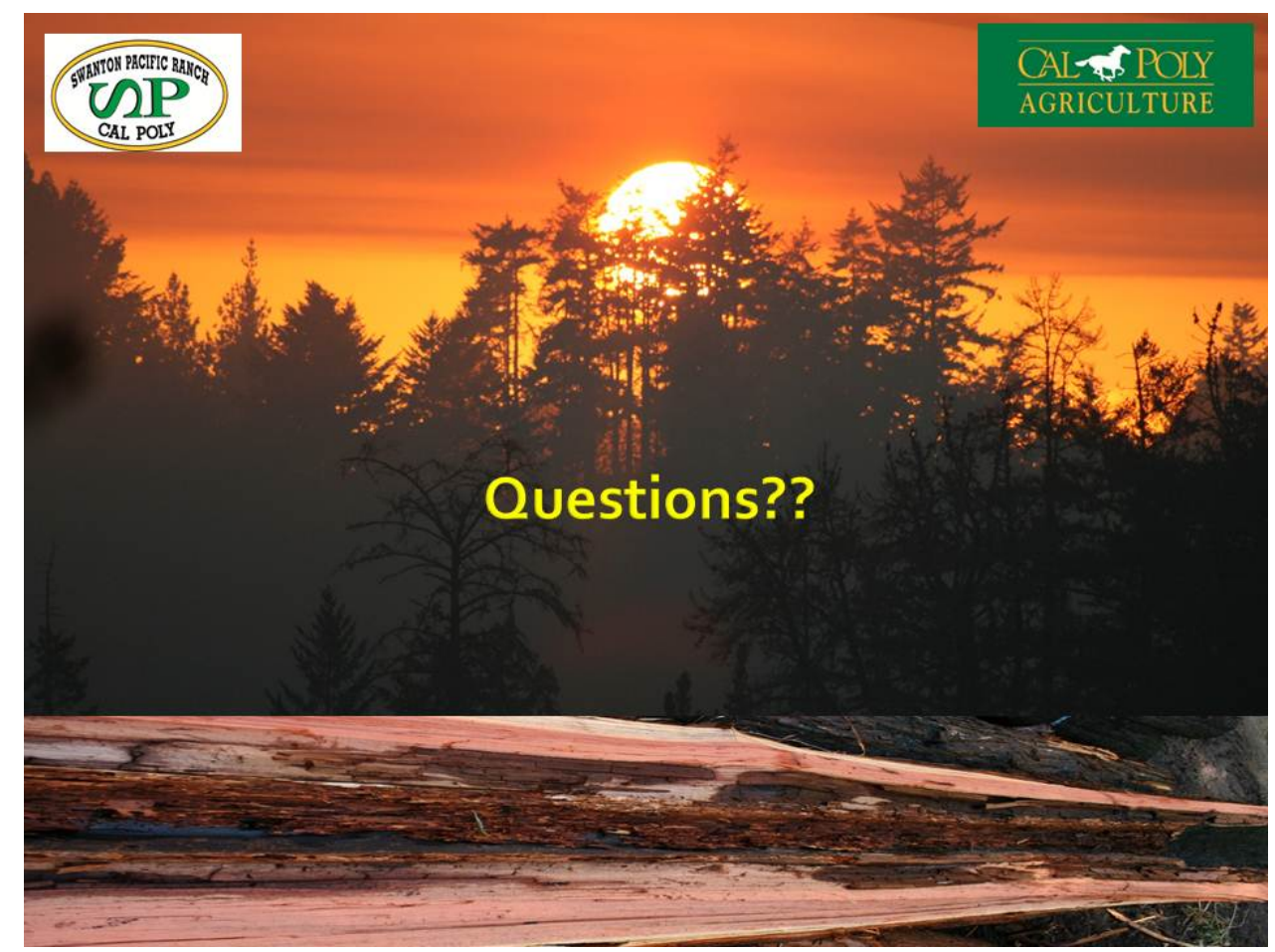

